\title{
norden
}

Fagintegreret læseundervisning for kortuddannede voksne 

U nordon 



\section{Fagintegreret læseundervisning for kortuddannede voksne}

Ina Borstrøm og Dorthe Klint Petersen

TemaNord 2012:526 



\section{Fagintegreret læseundervisning for kortuddannede voksne}

Ina Borstrøm og Dorthe Klint Petersen

TemaNord 2012:526

ISBN 978-92-893-2351-2

http://dx.doi.org/10.6027/TN2012-526

(C) Nordisk Ministerråd 2012

Omslagsfoto: ImageSelect

Tryk: Rosendahls - Schultz Grafisk

Oplag: 300

Printed in Denmark

Denne rapport er udgivet med finansiel støtte fra Nordisk Ministerråd. Indholdet i rapporten afspejler dog ikke nødvendigvis Nordisk Ministerråds synspunkter, meninger, holdninger eller anbefalinger.

www.norden.org/da/publikationer

\section{Det nordiske samarbejde}

Det nordiske samarbejde er en af verdens mest omfattende regionale samarbejdsformer. Samarbejdet omfatter Danmark, Finland, Island, Norge og Sverige samt Færøerne, Grønland og Åland.

Det nordiske samarbejde er både politisk, økonomisk og kulturelt forankret, og er en vigtig medspiller i det europæiske og internationale samarbejde. Det nordiske fællesskab arbejder for et stærkt Norden i et stærkt Europa.

Det nordiske samarbejde ønsker at styrke nordiske og regionale interesser og værdier i en global omverden. Fælles værdier landene imellem er med til at styrke Nordens position som en af verdens mest innovative og konkurrencedygtige regioner.

\section{Nordisk Ministerråd}

Ved Stranden 18

1061 København K

Telefon (+45) 33960200

www.norden.org 


\section{Indholdsfortegnelse}

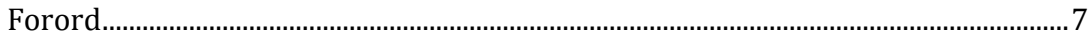

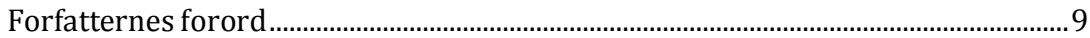

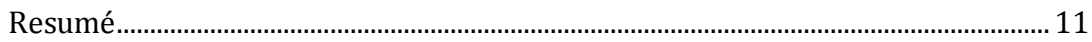

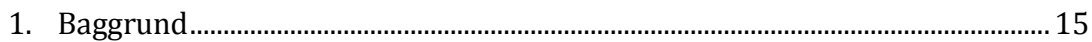

1.1 Læsekrav i job og uddannelse ................................................................. 18

1.2 Hvordan făr man gruppen i tale? ............................................................. 20

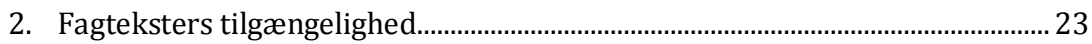

2.1 Analyse af læsekrav i konkrete lærebøger ................................................ 26

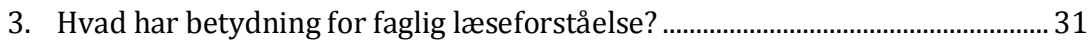

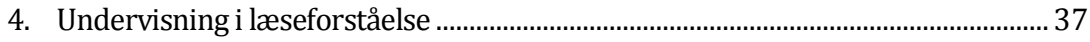

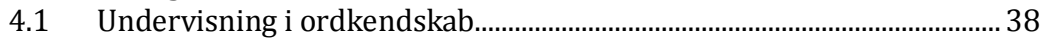

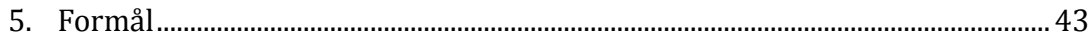

6. Udvælgelse af undervisningssted.................................................................... 45

7. Udvælgelse af fagområde til den fagintegrerede læseundervisning .................. 49

8. Analyser af fagteksters tilgængelighed på SOSU ....................................................53

8.1 Automatisk analyse - sproglig varedeklaration ...................................... 54

8.2 Manuel analyse - sproglige udfordringer ved fagtekster........................ 56

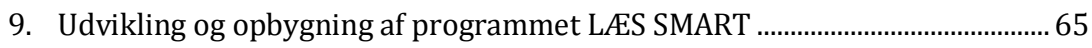

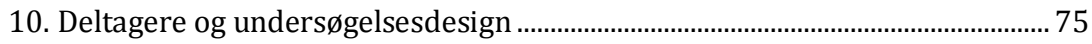

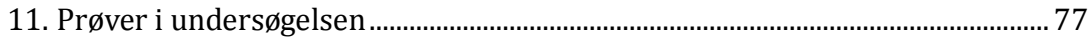

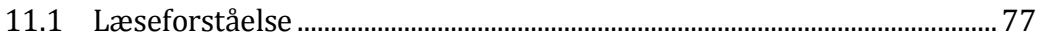

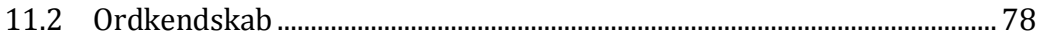

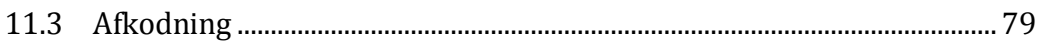

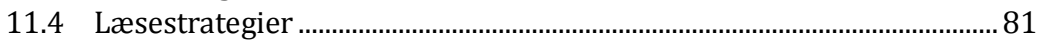

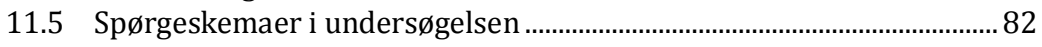

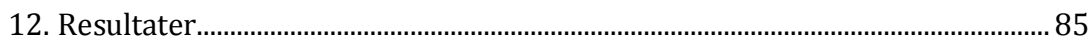

12.1 SOSU-kursisternes baggrundsoplysninger og læsevaner ....................... 85

12.2 Hvordan er SOSU-kursisternes skriftsproglige færdigheder?................ 87

12.3 Hvad kan forklare variation i læseforståelse? ........................................... 93

12.4 Hvad sker der med SOSU-kursisternes færdigheder i løbet af

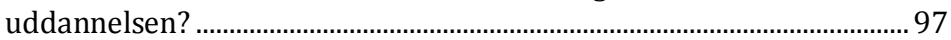

12.5 Sammenhænge mellem læsevaner og læsefærdighed ............................ 99 
13. Er der en særlig effekt af LÆS SMART forløbet? ................................................. 101

13.1 Effekt af LÆS SMART ................................................................................ 101

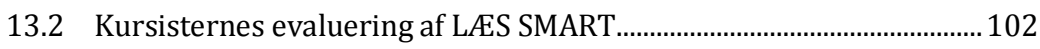

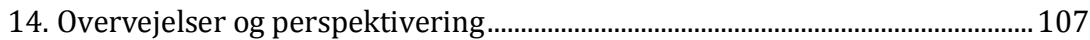

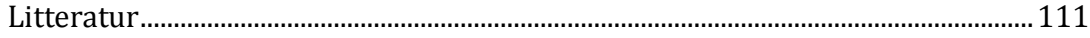

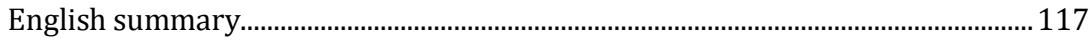




\section{Forord}

Basale læse- og skrivefærdigheder er en afgørende faktor for, at mennesker i en stadig mere kundskabsbaseret verden kan deltage aktivt i både samfunds- og arbejdslivet. EN OECD-undersøgelse fra 2000 viser imidlertid, at en relativ stor del af de voksne i Norden har vanskeligheder med at læse. Således klarer omkring en tredjedel af deltagerne i de nordiske lande sig under det niveau, som i undersøgelsen blev fastlagt som minimumskrav.

Samtidig viser undersøgelser, at mange kortuddannede med ringe læse- og skrivefærdigheder er tilbageholdende med at deltage i kurser og uddannelse. Hvis denne gruppe skal motiveres til at forbedre deres læseog skrivefærdigheder, kan det være hensigtsmæssigt at tilrettelægge undervisningen, så den tager udgangspunkt i de fagområder, som deltagerne arbejder inden for, eller de krav, de møder til daglig i arbejds- eller uddannelsessammenhæng.

På den baggrund bevilgede Nordisk Ministerråd i efteråret 2009 midler til en undersøgelse af fagintegreret læseundervisning for kortuddannede voksne. Formålet med undersøgelsen var at udvikle og afprøve et undervisningsforløb, der tog udgangspunkt i læsekravene i en konkret uddannelse, og at undersøge effekten af et sådant undervisningsforløb på deltagernes læse- og skrivefærdigheder.

Undersøgelse blev afviklet på Social- og sundhedshjælperuddannelsen i Greve. Undersøgelsen viste, at godt halvdelen af kursisterne på Social- og sundhedshjælperuddannelsen i Greve har svært ved at læse og få udbytte af at læse hverdagstekster og fagtekster.

Kursisternes færdigheder udviklede sig på nogle områder i løbet af uddannelsen. Udviklingen var især knyttet til områder, som lå tæt på det, der blev arbejdet med i undervisningen. Kursisterne blev bedre til at forstå sundhedsfaglige tekster, fik et bedre sundhedsfagligt ordkendskab og blev bedre til at navigere i sundhedsfaglige tekster. Men samtidig blev kursisterne også bedre til afkodning og bedre til at forstå almindelige 
hverdagstekster, sandsynligvis fordi de ved at starte på et uddannelsesforløb fik trænet deres generelle færdigheder.

Vi håber, at rapporten kan bidrage til, at der sættes fokus på, hvilke særlige læsekrav en fagbog stiller til sin læser, og dermed give inspiration og læring for alle, der arbejder med at styrke voksnes læse- og skrivefærdigheder.

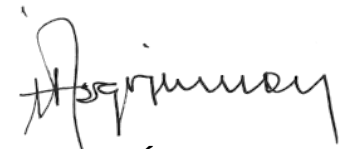

Halldór Ásgrímsson

Generalsekretær

Nordisk Ministerråd 


\section{Forfatternes forord}

- Hvilke særlige læsekrav stiller en fagbog?

- Hvordan kan man undervise voksne i faglig læseforståelse?

- Hvordan arbejder man med faglig forståelse og faglig læseforståelse på samme tid?

Der er mange spørgsmål omkring faglig læsning, som venter på at blive besvaret. Og det er nogle af disse spørgsmål, som dette projekt belyser.

Projektet er finansieret af Nordisk Ministerråd, hvortil vi vil rette en særlig tak til seniorrådgiver Kirsten Preisler. Projektet er bestilt af Styringsgruppen for Voksnes læring, som har fulgt projektet med stor interesse og bidraget med spændende kommentarer og indspark. En stor tak skal også lyde til medlemmerne af projektets nordiske referencegruppe, Ph.d.-studerende Anna Gellert, Københavns Universitet (DK), Prorektor Egil Gabrielsen, Stavanger Universitet (N) og Docent Monica Reichenberg (S). Referencegruppens medlemmer har bidraget med perspektiverende kommentarer og faglige råd undervejs i processen. Og endelig tak til projektets leder professor Carsten Elbro, Københavns Universitet (DK) og til studentermedhjælp Mathilde Gottschau.

Projektet havde slet ikke været muligt at gennemføre uden en lang række personers aktive medvirken. I den forbindelse vil vi gerne takke ledelse og ansatte på SOSU-Greve, der har stillet deres arbejdsplads til rådighed for projektet. En stor tak skal lyde til læsevejleder Bodil Pedersen, der har forestået testningen på de udvalgte hold, hele tiden har sikret den nødvendige forbindelse mellem projekt og undervisning og velvilligt har besvaret spørgsmål fra alle sider.

Projektets fokus har været den fagintegrerede læseundervisning, og derfor har vi været helt afhængige af de to projektundervisere i Sundhedsfag, Anni Bindslev Schytte og Helene Damgård. Vi er taknemmelige for, at de har stillet deres fag, undervisningstid og personlige engagement til rådighed for det fagintegrerede læseforløb. Og sidst med ikke mindst vil vi 
takke de kursister på SOSU-Greve, der har deltaget i testning og i fagintegreret læseundervisning undervejs i deres uddannelse. Vi ved, at opgaverne var tidskrævende og ikke altid lige nemme, men alligevel har kursisterne taget udfordringen op. Tak for det.

\author{
Ina Borstrøm \\ Dorthe Klint Petersen \\ København, 2012
}




\section{Resumé}

Nordisk Ministerråd bevilligede i efteråret 2009 penge til en effektundersøgelse med fagintegreret læseundervisning for kortuddannede voksne. Formålet med denne undersøgelse var at udvikle og afprøve et undervisningsforløb, der tog udgangspunkt i læsekravene i en konkret uddannelse, og at evaluere udbyttet af det gennemførte undervisningsforløb.

Undersøgelsen blev afviklet på sundhedshjælperuddannelsen i Greve. Valget faldt på SOSU-hjælper af flere forskellige grunde. Sundhedshjælperuddannelsen er en uddannelse med overrepræsentation af svage læsere. Der er skriftsproglige krav både i uddannelsen og i senere erhverv. Uddannelsen er en vekseluddannelse med skoleforløb og praktikperioder, og der indgår skriftsprog i de primære arbejdsopgaver. Endelig er SOSUhjælper et fagområde, der er blevet voldsomt teoretiseret. Fra tidligere at være et kursus på 9 uger er uddannelsen nu et forløb på 1 år og 7 måneder. Undersøgelsen indbefattede også en analyse af læsekravene på uddannelsen, og derfor var det en yderligere fordel, at man på SOSU arbejdede med samme materiale over det meste af landet.

Næste trin i projektforløbet var at udvælge det fagområde, der skulle være genstand for den fagintegrerede læseundervisning. For at kunne træffe det rigtige valg undersøgte vi forskellige ting. Ved årsskiftet 2009/2010 sendte vi et spørgeskema til henholdsvis lærere og elever på SOSU-Greve. I besvarelserne gav lærerne udtryk for, at elevernes skriftsproglige færdigheder satte begrænsninger i den daglige undervisning. Eleverne fortalte, at teksterne i visse fag var meget vanskelige. På baggrund af spørgeskemaundersøgelsen udvalgte vi et områdefag (sundhedsfag), et grundfag (naturfag) og et PBL-forløb, som vi vurderede særligt indgående. I foråret 2010 observerede vi undervisning på Social- og sundhedshjælperuddannelsen i Greve i de tre nævnte fag med henblik på at udvælge det fag, der var mest velegnet til et fagintegreret læseforløb. Valget faldt på sundhedsfag, fordi det var et kernefag i uddannelsen, den gen- 
nemgående grundbog blev anvendt aktivt i dette fag, og endelig fordi kursisterne virkede meget engagerede og optagede af dette fag.

Der blev lavet en række sproglige analyser af grundbogen til Sundhedsfag, og disse analyser viste, at bogen indeholder mange passivkonstruktioner og har en høj informationstæthed, men at den generelt ikke har en større sproglig sværhedsgrad end andre fagtekster. Omvendt vil de forskellige teksttyper i bogen kræve viden om særlige læseteknikker. På samme måde vil tilegnelsen af såvel det særlige fagsprog som det samlede faglige indhold kræve særlige studieteknikker.

Der er urealistisk at foretage en gennemgribende sproglig analyse af alle fagtekster på en given uddannelse og efterfølgende at bearbejde samtlige tekster sprogligt. I stedet bør man fokusere på de særlige læsekrav, der stilles i fagtekster, og lære kursisterne de nødvendige forståelsesstrategier.

Der blev udviklet et undervisningsprogram, LÆS SMART, hvor kursisterne skulle arbejde med læseforståelsesstrategier i Sundhedsfag. I LÆS SMART indgik fire forskellige hovedelementer i et samlet træningsforløb, der bestod af 20 moduler med efterfølgende implementeringsfase, hvor kursisterne skulle bruge strategiarkene fra forløbet i forbindelse med lektielæsningen. Der var en "før-læse“-strategi, en „mens du læser“strategi og to „efter du har læst“-strategier. Programmet blev udviklet på baggrund af resultater fra metaanalyser om effektive metoder til undervisning i læseforståelse. I LÆS SMART arbejdede kursisterne med teksttypekendskab, aktivering af forhåndsviden, ordkendskab, træning i at stille spørgsmål til teksten, opsummering og med at drage følgeslutninger. Arbejdet med strategierne blev tilrettelagt $\mathrm{i}$ faser, hvor man startede med en introduktion, der blev efterfugt af en fase, hvor undervisere modellerede strategien. Herefter skulle kursisterne træne strategien med en makker for derefter at træne strategien hjemme på egen hånd. Afslutningsvis blev strategien repeteret i klassen, hvorefter kursisterne blev opfordret til at bruge strategien i forbindelse med lektielæsningen for at sikre den endelige implementering.

I forbindelse med afprøvningen af LÆS SMART blev kursisternes færdigheder afdækket på en lang række områder før og efter træningsforløbet. Dette gav mulighed for at undersøge, om der var effekt af undervisningen generelt, eller om der var effekt på specifikke områder. Før og efter træningsforløbet afdækkedes kursisternes almene og faglige læseforståel- 
se samt deres afkodning, almene og faglige ordkendskab, kendskab til teksttyper og metakognitive strategier. Endelig blev kursisternes læsevaner og baggrund afdækket ved hjælp af forskellige spørgeskemaer. De kursister, der deltog i LÆS SMART-forløbet, blev efterfølgende bedt om at evaluere træningsforløbet.

Afdækningen af kursisternes færdigheder gav mulighed for at se nærmere på, hvad der karakteriserede gruppen som helhed, om der var en udvikling i gruppens færdigheder, og endelig om der var en særlig effekt af LÆS SMART-forløbet.

Undersøgelsen viste, at godt halvdelen af kursisterne på sundhedshjælperuddannelsen i Greve har svært ved at læse hverdagstekster og fagtekster med udbytte. En stor del af denne variation kan forklares ud fra forskelle på kursisternes ordkendskab, afkodning og kendskab til teksttyper.

Kursisternes færdigheder udviklede sig på nogle områder i løbet af uddannelsen. Udviklingen var især knyttet til områder, som lå tæt på det, der var arbejdet med i undervisningen. Kursisterne blev bedre til at forstå sundhedsfaglige tekster, fik et bedre sundhedsfagligt ordkendskab og blev bedre til at navigere i sundhedsfaglige tekster. Men samtidig blev kursisterne også bedre til afkodning og bedre til at forstå almindelige hverdagstekster, sandsynligvis fordi de ved at starte på et uddannelsesforløb fik trænet deres generelle „læsekondi“.

Der var ikke nogen specifik effekt af at deltage i LÆS SMART-forløbet. LÆS SMART-kursisterne gik ikke mere frem på læsemålene end de øvrige kursister, men alligevel udtrykte LÆS SMART-kursisterne tilfredshed med forløbet. Mange giver udtryk for, at de har lært nogle strategier, som de allerede bruger og/eller vil bruge i deres (videre)uddannelse og erhverv. Dette svarer til resultaterne fra andre undersøgelser, der ikke påviser træningseffekt på objektive læsemål efter en afgrænset træningsperiode, men hvor deltagerne selv vurderer, at de har fået et brugbart redskab (se eksempelvis Arnbak \& Borstrøm, 2004). Det kan være den nødvendige „kickstart“, der på længere sigt også vil skabe positiv effekt på kursisternes læseforståelse. 



\section{Baggrund}

Langt de fleste voksne i Norden har lært at læse. Udfordringen er at få så mange voksne som muligt til at læse godt nok, dvs. til at øge deres kompetence fra en basal læsefærdighed til en funktionel læsefærdighed. Funktionel læsefærdighed vil sige, at man forstår, kan anvende og reflektere over skrevne tekster, så man kan nå sine mål, udvikle sin viden og sit potentiale og kan deltage aktivt i samfundslivet (OECD/PISA, 1998).

Den funktionelle læseudvikling kan opdeles i faser, som delvis overlapper hinanden, og hvor man hele tiden gør brug af læseteknikker fra de tidligere faser.

Den tekniske læsning dækker over den periode, hvor en person knækker den alfabetiske kode og læser for at lære at læse.

Den flydende læsning dækker over perioden, hvor en person konsoliderer sin læsning gennem læsning af mange og lange fortløbende sider og primært læser for oplevelsens skyld.

Den fleksible læsning dækker over perioden, hvor en person læser et varieret udvalg af tekster og læser med bestemte formål, som afspejles dels i tekstens opbygning og dels i personens læsemåde.

\section{Funktionel læseudvikling}

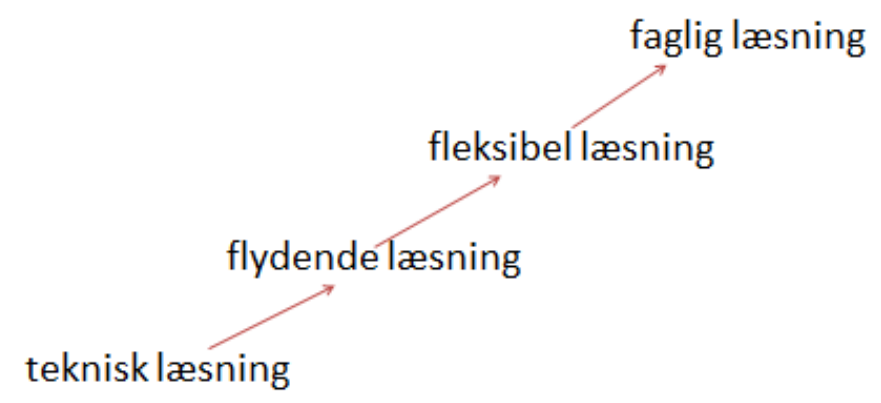


Gennem disse faser skabes basis for den faglige læsning, hvor personen sammenholder informationer fra flere forskellige tekster og teksttyper og læser for at lære. Faglig læsning er tilegnelsen af viden gennem skrift og udgør den sidste fase i den funktionelle læseudvikling. Både forhåndskendskab til det faglige emne og generel læseforståelse har betydning for den faglige læseforståelse (Gellert, 1999).

I Danmark blev offentligheden opmærksom på voksnes utilstrækkelige læsefærdighed, da det i starten af 1990erne blev dokumenteret, at omkring en kvart million danskere ikke fik tilstrækkeligt udbytte af almindelige hverdagstekster (Elbro, Møller \& Nielsen, 1991). Dette resultat blev cementeret og understreget i SIALS, Second International Adult Literacy Survey (Jensen \& Holm, 2000), der fandt, at $45 \%$, eller hvad der svarer til ca. 1 million voksne danskere, havde utilstrækkelig læsefærdighed. Selvom de andre nordiske lande klarede sig en smule bedre i den internationale målestok (Sverige $28 \%$, Norge $33 \%$, Finland $37 \%$ ), så blev det en øjenåbner i hele Norden for den samfundsmæssige betydning af, at store dele af befolkningen ikke i tilstrækkelig grad forstår, hvad de læser i dagligdagen. I kølvandet på de generelle undersøgelser blev det påvist, at de kortuddannede voksne er stærkt overrepræsenterede i gruppen af svage læsere. Eksempelvis placerede hele $79 \%$ af danskere uden uddannelse sig i gruppen med utilstrækkelige læsefærdigheder, ligesom lidt over $60 \%$ af nordmænd uden uddannelse havde utilstrækkelig læsefærdighed både i SIALS og i den nyere undersøgelse ALL fra 2003, hvor Norge deltog som det eneste nordiske land (Gabrielsen, Haslund \& Lagerstrøm, 2005).

Dette blev startskuddet til en række undervisningstiltag, projekter og ekstrabevillinger, som alle skulle bidrage til at dokumentere voksnes reelle læsebehov i deres hverdag og sætte fokus på muligheden for at modtage læseundervisning i relevante hverdagstekster og dermed for at højne den nordiske voksne befolknings læsefærdighed. En samlet beskrivelse af disse tiltag findes i en nordisk forundersøgelse fra 2007, som gennemgår de eksisterende undervisningstilbud og udbyttet af disse tiltag (Gellert et al, 2007). Rapporten giver dels et overblik over bredden af undervisningstilbud og dels en eksemplificeret gennemgang af tre udvalgte undervisningsforløb fra henholdsvis Norge, Sverige og Danmark, som kan inspirere fremtidens undervisere. I de tre forløb indgår en subjektiv deltagervurdering af undervisningens betydning, men ikke en systematisk afdækning af 
deltagernes færdigheder før og efter undervisning, Derfor er det vanskeligt med sikkerhed at vide, om de valgte eksempler på undervisning faktisk er bedre end andre tiltag. Det samme gælder for beskrivelsen af 12 gode undervisningseksempler (best practice), som det danske Undervisningsministerium har udgivet (Møller, 2010).

For at få svar på spørgsmålet om særlig effektive metoder eller undervisningsforløb, må man kræve egentlige effektundersøgelser, som ikke alene baserer sig på deltagernes oplevelse af fremgang, men som indeholder en vurdering af deltagernes faktiske fremgang. Undersøgelser viser, at kursister har svært ved at vurdere eget læseniveau (se fx Elbro, Møller og Nielsen, 1991). Eksempelvis kunne man i en undersøgelse inden for den kompenserende specialundervisning for ordblinde ikke påvise en sammenhæng mellem elevernes oplevede fremgang og den faktiske udvikling i læsning og stavning (Holders, Petersen, Borstrøm \& Elbro, 1996). Selvom det sandsynligvis er et vigtigt skridt på vejen til bedre læsning på længere sigt, at deltageren har oplevet en fremgang og dermed har oplevet en nytteværdi ved at deltage i undervisning, så skal man således være meget påpasselig, hvis man alene baserer sine evalueringer af læse- og skriveforløb på deltagernes selvvurderinger.

Der findes enkelte nordiske effektundersøgelser inden for området. I et svensk tilbud om læse- og staveundervisning for arbejdsløse med læse/stavevanskeligheder gik deltagerne signifikant mere frem på stavning, afkodning, hukommelse og selvtillid end en gruppe tilsvarende arbejdsløse, der modtog et tilbud uden læsning og stavning. I Danmark er der i den kompenserende specialundervisning for voksne (ordblindeundervisning) lavet to undersøgelser, der begge viser en beskeden fremgang inden for læsning og stavning for gruppen som helhed og en væsentlig fremgang for en mindre del af gruppen (Holders et al 1996; Lau et al 1995). Den ene danske undersøgelse påviste desuden en sammenhæng mellem elevernes udbytte og undervisningens intensitet (Lau et al 1995). Imidlertid er der $\mathrm{i}$ de tre nævnte undersøgelser tale om uspecificerede undervisningsforløb, og derfor kan det være svært at isolere de undervisningselementer, der var særlig effektive og dermed er værd at kopiere. En enkelt dansk undersøgelse har været tilrettelagt med to veldefinerede undervisningsforløb for to grupper af deltagere i forberedende voksenundervisning, FVU. De to grupper blev sammenlignet med en tredje gruppe, der modtog et uspecifi- 
ceret FVU-tilbud (Arnbak \& Borstrøm, 2004). Undersøgelsen viste en beskeden, men dog signifikant fremgang for alle FVU-deltagere på både afkodning, læseforståelse, stavning og skrivning, og derudover anvendte træningsgrupperne skriftsproget mere i dagligdagen og opnåede en mere realistisk vurdering af deres udbytte af undervisningen end kontrolgruppens deltagere.

Samlet indikerer resultaterne fra de nævnte undersøgelser, at læse- og stavefærdigheden kan forbedres hos voksne med læse- og stavevanskeligheder, men at det kræver intensiv undervisning, og at fremgangen ofte er beskeden i forhold til det gab, der er mellem deltagerens læseniveau og hverdagens læsekrav. Desuden kan de mange uspecificerede undervisningstilbud gøre det svært at systematisere de pædagogiske og didaktiske erfaringer, så de kan bruges i den fortsatte udvikling af en effektiv voksenundervisning.

\subsection{Læsekrav i job og uddannelse}

Der er stor forskel på kravene til skriftsproglige færdigheder på forskellige arbejdspladser og i forskellige jobfunktioner (Mikulecky, 1998; 2000; Barton, 2000). Alligevel er det svært at klare sig på nutidens arbejdspladser med utilstrækkelig læsefærdighed, hvis man skal honorere samtlige jobkrav. Poul Barton har i en årrække analyseret og fulgt læsekravene i forskellige jobfunktioner, og hans arbejde viser, at der inden for alle brancher blev krævet en funktionel læsefærdighed i langt de fleste jobfunktioner (Barton, 2000).

Bartons faglige vurdering af høje læse- og skrivekrav i de fleste jobfunktioner skal ses i forhold til mange ufaglærte voksnes subjektive fornemmelse af, at læsning og stavning kun i mindre omfang indgår i deres daglige arbejde. Forskellen kan skyldes, at voksne med praktisk betonet arbejde ofte kun læser og skriver i kort tid ad gangen i forbindelse med løsning af konkrete jobfunktioner. Dette gælder de såkaldte primære jobfunktioner, hvor læse- og skrivekravet ikke har ændret sig væsentligt over tid. Til gengæld er der sket voldsomme ændringer i de sekundære jobfunktioner, hvor mødedeltagelse, planlægning af arbejdsgange, kvalitetskontrol og dokumentation for det udførte arbejde eller systemfejl ofte 
stiller større krav til sammenhængende læsning og skrivning (Hull et al, 1996; Karlsson, 2006; Pedersen \& Løvengreen, 2006). De fleste arbejdspladser og ansættelser vil således kræve mere læsning og stavning, end man umiddelbart gør sig klart, fordi læse- og skrivekravet ikke kun er knyttet til den primære faglighed og arbejdsopgave.

Endelig viser Bartons undersøgelser, at læsekravet er snævert forbundet med krav om eksamen og (efter)uddannelse. En medarbejders værdi måles ikke længere kun på, hvordan den konkrete jobfunktion varetages i dag. En god medarbejder skal også være klar til (videre)uddannelse for at kunne varetage fremtidige jobfunktioner. Voksne uden eksamen og uddannelse er således i stor risiko for at blive marginaliserede i informationssamfundet (Barton, 2000).

Undersøgelser af industriarbejdere med forskellige jobfunktioner peger på, at de primært læser enkeltord og korte sekvenser og kun ganske sjældent læser længere, sammenhængende tekster (Gustavsson, 2002). På en uddannelse vil man derimod blive mødt af mere massive og forskelligartede læseopgaver. Hvis man som voksen lever op til de læse- og skrivekrav, der hører til uddannelsen, så er der således stor chance for, at man også vil kunne honorere de læse- og skrivekrav, der er indbygget i ens (fremtidige) erhverv.

I den almene voksenundervisning, AVU, og på de fagligt rettede arbejdsmarkedsuddannelser, AMU, ses en stor andel af deltagere med massive læsevanskeligheder (Arnbak \& Elbro, 1999; Arnbak, 1999). Det er dokumenteret, at AMU-deltageres forståelse af fagtekster inden for deres område ofte er meget ringe (Møller \& Nielsen, 1986), og at der er sammenhæng mellem læsefærdighed og det faglige udbytte på AVU målt på eksamenskarakterer (Arnbak \& Elbro, 1999). Der er således stor afstand mellem kortuddannedes funktionelle læsefærdigheder og de massive læse- og stavekrav, der stilles på uddannelsen. Det er sandsynligt, at en lang række undervisningsaktiviteter i praksis udføres uden brug af den skriftlighed, som opgaven egentlig lægger op til, og som undervisningsstedet implicit forventer. Skriftligheden kan fx nedtones ved, at underviseren gennemgår det faglige indhold mundtligt, eller at eleverne indgår i teams, hvor andre kan påtage sig den skriftlige del af arbejdet. Men jo sjældnere, man bliver stillet over for tydelige skriftsproglige krav, jo vanskeligere kan det være at honorere de skriftsproglige krav, når de forekommer. Hvis 
man undlader at styrke de kortuddannedes evne til at tilegne sig viden gennem tekst i forbindelse med deres uddannelse (enten i den egentlige undervisning eller på supplerende læsekurser), så vil de naturligvis også savne denne kompetence i deres fremtidige erhverv.

\subsection{Hvordan får man gruppen i tale?}

En vigtig problemstilling omkring læseundervisning for kortuddannede voksne er, hvordan man får motiveret denne gruppe til at modtage den relevante læse- og skriveundervisning. Undersøgelser har påpeget en ringe sammenhæng mellem de faktiske læsefærdigheder og de voksnes egen oplevelse af læseniveau (Elbro, Møller \& Nielsen, 1991; Jensen \& Holm 2000b). De voksne har en generel tendens til at overvurdere egne evner i forhold til læsning og skrivning, og derfor er de selvsagt svære at motivere til at modtage ekstra undervisning. Ingen går vel på kursus om livstilsændring, hvis de mener, at de spiser sundt. Det er sandsynligt, at man i praksis måler sin læsning på, om man kan honorere dagligdagens krav til læsning.

Flere nordiske undersøgelser har dokumenteret, at ufaglærte læser og skriver mindre på arbejdet end personer med en uddannelse ud over grundskolen (Gabrielsen, 2000; Jensen, Andersen \& Halgreen, 2001; Gustavsson, 1997). I en dansk undersøgelse baseret på telefoninterview oplyste ca. $94 \%$ ufaglærte eller kortuddannede voksne, at det var let eller meget let at læse det, de skulle i forbindelse med deres arbejde. Andelen af folk, der mente, at det var let eller meget let at læse tekster på deres arbejde, var større i denne gruppe end i andre faggrupper (Undervisningsministeriet 2005). Hvis man kun i begrænset omfang har brug for at læse og stave på arbejdet, så vil man sandsynligvis ikke føle, at læsning og stavning udgør en barriere i dagligdagen, og dette kan begrænse lysten til at søge ekstra undervisning i læsning og stavning. Omvendt kan deltagelse i efter- og videreuddannelse muligvis øge voksnes opmærksomhed på deres (utilstrækkelige) læse- og stavefærdighed. Det ser imidlertid ud til, at der er en dobbelt barriere med hensyn til uddannelsesniveau og læsefærdigheder. Unders $\emptyset$ gelser viser, at ufaglærte i gennemsnit deltog mindre i faglige kurser end personer med uddannelse ud over grundskolen. Dette gjaldt især for ufag- 
lærte med ringe læsefærdigheder, hvoraf kun $20 \%$ havde deltaget i et fagligt kursus i løbet af det seneste år (Jensen, Andersen \& Halgreen, 2001). Om det er læseniveauet, der for de ufaglærte sætter en begrænsning for deres ønske om faglige kurser, eller om det er manglende faglige kurser, der begrænser gruppens indsigt i egen læse- og stavning, er umuligt at sige. Men det er et faktum, at man i de nordiske lande ønsker, at befolkningen som helhed skal forbedre deres basale færdigheder, så de kan ændre jobfunktioner og opkvalificere sig gennem videreuddannelse i et livslangt perspektiv (Trepartsudvalget, 2006).

Ved at knytte det gratis tilbud om læse- og staveundervisning for voksne (FVU) tættere til arbejdsmarkedsuddannelserne (AMU) har man i Danmark forsøgt at motivere flere til at deltage i læse- og staveundervisning. Der er således skabt et åbent tilbud til alle på AMU om en afdækning af basale læse- og stavefærdigheder, og enkelte virksomheder har indført et tilsvarende tilbud til alle medarbejdere i produktionen (Møller, 2010). Men selvom flere er blevet screenet og læsetestet, så er det fortsat svært at få tilstrækkelig mange til at deltage i tilbuddet om gratis læseundervisning. Eksempelvis kan det nævnes, at Trepartsudvalget i 2006 estimerede antallet af danskere med ringe læsefærdigheder til 150.000 personer og antallet af danskere med utilstrækkelige læsefærdigheder til ca. 800.000 personer. Tallene for 2010 viser, at godt 23.000 voksne modtog FVUundervisning i læsning og stavning, og at langt de fleste modtog undervisning rettet mod basale læse- og stavevanskeligheder. Der er således meget langt fra de 150.000 svageste læsere eller de 800.000 voksne med funktionelle vanskeligheder til det antal af voksne, der årligt yder en ekstra indsats for at forbedre deres basale færdigheder, og tallene tyder på, at dem, der frivilligt deltager i ekstra læse- og staveundervisning, er dem, der ikke kan læse, mens dem, der godt kan læse, men ikke kan læse godt nok, ikke deltager i ekstra undervisning.

Der tegner sig således et billede af, at for få voksne får tilbudt eller tager imod et tilbud om ekstra læse- og stavetræning. En af grundene kan være, at for mange ikke er opmærksomme på de indbyggede læsekrav, der ligger i de fleste jobfunktioner, samarbejdsrelationer og efteruddannelseskurser. På den baggrund er det oplagt at arbejde med fagintegreret læseundervisning for alle deltagere på (efter)uddannelser for unge og voksne med kort eller ingen uddannelse. Fordelene ved at fagintegrere 
læseundervisningen er, at man når en større del af målgruppen, og at undervisningen fra start knytter forbindelse til den faglige undervisning. Eleverne får fornemmelsen af at arbejde med noget relevant, når de gennem øvelserne ikke alene forbedrer deres læseteknikker, men samtidig øger indsigten i deres fag.

Problemstillinger, der bør indgå i indsatsten for at skabe et kompetenceløft i Norden blandt gruppen af u- eller kortuddannede voksne, kan således sammenfattes i følgende punkter:

- Mange u- eller kortuddannede voksne i Norden har funktionelle læsevanskeligheder

- Der er stor afstand mellem de voksnes funktionelle færdigheder og det niveau, der kræves i forbindelse med (videre)uddannelse

- For få voksne erkender eller opdager deres funktionelle læsevanskeligheder i dagligdagen og søger hjælp til at styrke deres funktionelle læsefærdighed

- Mange undervisningstilbud, der træner voksnes funktionelle læsefærdighed, placeres som et tilbud uden for arbejds- eller undervisningstid. Undervisningen er ofte tilrettelagt i forbindelse med, men uden direkte tilknytning til den voksnes erhverv eller uddannelse

- Rapporter om forsøgsundervisning, der træner voksnes funktionelle færdigheder, indeholder ofte erfaringsopsamlinger, men sjældent dataindsamlinger, der kan dokumentere en eventuel effekt på læsning og stavning 


\section{Fagteksters tilgængelighed}

En fagbog skal være tilrettelagt, så læseren er i stand til at tilegne sig ny faglig viden på egen hånd. En god fagbog formidler således det faglige stof så præcist og tilgængeligt som muligt. Det kræver, at man på den ene side introducerer og bruger nye fagudtryk, og at man på den anden side udarbejder teksten så nemt sprogligt, at tekstens kompleksitet ikke er en unødig forhindring for læseren.

Sproglige forhindringer kan optræde på både tekstniveau, sætningsniveau og ordniveau. Sproglige forhindringer kan eksempelvis optræde på tekstniveau, hvis tekstsammenhængen er utydelig (dårlig kohæsion), eller hvis teksten indeholder en springende komposition, der beskriver konsekvensen før årsag eller betingelse. En faglig formidling, der ikke definerer tekstens formål klart fra start og opsummerer tekstens indhold til slut, gør teksten svær at forstå og huske, selvom den enkelte sætning i sig selv er kort og sprogligt lettilgængelig.

Sproglige forhindringer kan også optræde på sætningsniveau, hvis teksten har en kompleks syntaks. En tekst med flere sætningsled inden udsagnsleddet (tungt forfelt) eller lange, komplicerede sætninger med indskudte ledsætninger på forskellige niveauer kan virke uoverskuelig på læseren og gøre teksten svær at forstå. På samme måde kan en overdreven brug af passivkonstruktioner gøre teksten svær at læse og forstå, selvom de enkelte ord i sig selv er korte og relativt velkendte.

Endelig kan sproglige forhindringer optræde på ordniveau, hvis teksten indeholder mange sjældne ord og ukendte begreber eller fremmedord. Det kan også komplicere teksten, hvis man anvender hverdagsord i en særlig faglig betydning og fx bruger ordet „lus“ som betegnelse for en lille træklods. Endelig kan det komplicere teksten, hvis man bruger mange konstruerede navneord (nominaliseringer) som fx „optagning“ som begreb for at løfte nogen eller noget, fordi det kræver, at læseren selv indsætter de skjulte sætningsled. Et påfaldende ordvalg kan således gøre 
teksten svær at læse, selvom teksten har en tydelig opbygning og er skrevet med relativt simple sætninger.

Der er naturligvis også andre områder, der påvirker læserens tilegnelse af den enkelte fagtekst.

Tekstens overordnede emnevalg kan eksempelvis have stor individuel betydning for læserens motivation og læselyst og derigennem indirekte påvirke tekstens (indholdsmæssige) tilgængelighed. En tekst om international aktiehandel og en tekst om ændringer i regelsættet for fodbolddommere vil umiddelbart appellere til forskellige målgrupper med hver deres forforståelse og motivation for emnet. Dermed vil de to tekster have forskellig subjektiv sværhedsgrad, selvom de objektivt kan måles som lige svære på både tekst-, sætnings- og ordniveau. Endelig kan faktorer som påfaldende skrift eller dårlig kopikvalitet påvirke læserens indtryk af tekstens (visuelle) tilgængelighed. Men uanset, om teksten har en tiltalende visuel fremtoning og beskriver et relevant emne, så opleves teksten lettere eller sværere afhængig af, hvordan dette emne bliver formidlet i teksten. Det er denne del, som en analyse af tekstens tilgængelighed primært retter sig mod.

Den mest anvendte beregning af teksters sproglige tilgængelighed er læsbarhedsindexet LIX. Siden 1970'erne har man ved hjælp af dette simple måleredskab haft mulighed for at vurdere teksters sproglige tilgængelighed ud fra en trindelt skala. LIX er et samlet mål for tekstens gennemsnitlige meningslængde (antal ord fra punktum til punktum) og den procentvise andel af lange ord (ord på 7 eller flere bogstaver). Der er en god statistisk sammenhæng mellem LIX-tallet og læsernes vurdering af tekstens sværhedsgrad (Björnsson, 1971). Björnsson inddrog en række sproglige faktorer i sine analyser, inden ordlængde og antallet af ord fra punktum til punktum blev udvalgt som de parametre, der tilsammen gav den største sammenhæng med læserens vurdering. Den statistiske sammenhæng skyldes, at lange meninger ofte vil være sprogligt mere komplekse end korte meninger, og at lange ord ofte vil være mindre kendte og indeholde en mere kompleks bogstavkonstruktion end korte ord. Selv om lange meninger og ord i sig selv ikke udgør en vanskelighed, så er de to mål således et pålideligt pejlemærke for, hvordan tekstens syntaktiske kompleksitet og ordvalg påvirker læseren. LIX siger ikke noget om, hvad der præcis gør den enkelte tekst svær. Dermed kan LIX ikke bruges som 
redskab til at gøre tekster nemmere, men kan alene bruges til at vurdere tekstens sværhedsgrad i den konkrete form. LIX er et nemt og hurtigt mål, som fortæller, hvor svær teksten vil være at læse, men LIX siger intet om, hvor let eller svært det vil være at indlære det faglige indhold af teksten (Elbro, 2006).

Mange voksne læsere vil opleve, at de læser alle ord og sætninger korrekt i deres fagtekst, men at de alligevel har svært ved at forstå og lære, hvad der står. Det kan skyldes, at teksten indeholder så meget ny information, at det er svært at kapere. En tekst med mange sjældne ord indeholder mere information end en tekst, der udelukkende bruger velkendte ord i en normal betydning. Men selv sjældne ord kan med tiden føles bekendte. Hvis ordene gentages flere gange og bruges i forskellige sammenhænge, så vil læseren opleve, at ordet langsomt mister sin informationsværdi og føles velkendt. Derfor er der i lighed med LIX udarbejdet et mål for teksters informationstæthed. Målet for informationstæthed kombinerer oplysninger om ordets frekvens i sproget generelt og ordets frekvens i den konkrete tekst (Elbro, 2006). For at anvende målet for informationstæthed, må man vælge et ordmateriale, der skal danne grundlag for det "generelle ordvalg“. I en undersøgelse af danske læsebøger blev der således anvendt en liste over hyppige ord i danske børnebøger som reference (Borstrøm, Petersen og Elbro, 1999), mens den danske sprogforsker, Peter Juel Henrichsen, har anvendt et korpus på 45 mio. løbende ord fra Det Danske Sprog og Litteraturselskabs frekvensliste (Korpus 2000) samt frekvenslisten for ord i morgenavisen Berlingske (Korpus Berlingske-99) i vurderingen af voksenteksters informationstæthed. I den forbindelse har Henrichsen udarbejdet en skala for, hvordan informationstætheden vurderes i en voksentekst (Henrichsen, 2009).

Informationstæthed retter sig mod tekstens sværhedsgrad på ordniveau, og LIX-tallet retter sig mod en kombination af tekstens sværhedsgrad på sætnings- og ordniveau. Derimod findes der ingen udbredte vurderingsskalaer til at måle teksters tilgængelighed på tekstniveau. Hvis informationerne i teksten ikke præsenteres i en hensigtsmæssig rækkefølge, eller hvis der ikke i tilstrækkelig grad er lagt en „ruteplan“ ned over teksten, så øges tekstens sværhedsgrad på tekstniveau (Arnbak, 2003). Analyser af tekstens komposition og indholdsmæssige tilrettelæggelse er yderst tidskrævende, dels fordi en eller flere vurderingspersoner må læse teksten, før de kan vurdere tekstens disponering af stoffet, og dels fordi 
det er svært at kvantificere disse observationer og overføre dem til en pålidelig vurderingsskala.

Mange af de tekstelementer, der indgår i vurderingen af teksters tilgængelighed på tekstniveau, kan bidrage både til at imødekomme læseren og til at vanskeliggøre læsningen af teksten. Som udgangspunkt må man fx antage, at tekster med én gennemgående teksttype er lettere tilgængelige end tekster med mange tekstelementer af forskellige teksttyper. På den anden side, så er de forskellige teksttyper jo netop indrettet til at formidle forskellige informationer. Umiddelbart bliver det ikke lettere at læse en opskrift, hvis den er skrevet som en fortløbende, fortællende tekst. Tekster med illustrative grafer og figurer skal gøre det lettere at forstå det faglige indhold i brødteksten. På den anden side, så må linket mellem figurer og tekst være tydeligt for læseren, hvis de grafiske elementer skal virke efter hensigten. Det er således svært på forhånd at vurdere, om det enkelte tekstelement vil lette eller vanskeliggøre læsningen, men forudsætningen for, at elementerne letter læsningen, er, at læseren udnytter disse elementer. På den måde stiller komplekse tekster større krav til læserens forhåndsviden om stilistiske virkemidler i forskellige tekster. Det er sandsynligt, at de særlige faglige virkemidler vil lette den i forvejen gode læser, mens det vil vanskeliggøre læsningen for svage læsere.

\subsection{Analyse af læsekrav i konkrete lærebøger}

En tidligere dansk analyse af de skriftsproglige krav på udvalgte erhvervsog arbejdsmarkedsuddannelser viste, at teksterne kræver kendskab til et bredt udsnit af teksttyper, beherskelse af forskelige læsestrategier og et godt sprogligt fundament. Det sproglige fundament kræves både i form af almindeligt ordforråd samt kendskab til egentlige fagudtryk (Lund, K.; Bertelsen, E. \& Sørensen, M. S. 2006). Forfatterne til denne undersøgelse, der særligt retter sig mod overgangen mellem sprogcentre og erhvervsrettede uddannelser, vurderer, at en stor del af elevgruppen ikke kan tilegne sig det faglige indhold i grundbogsmaterialet på egen hånd. De vurderer endvidere, at de sproglige krav på erhvervs- og arbejdsmarkedsuddannelser på den ene side er en barriere for eleverne, men at det faglige sprogbrug på den anden side er nødvendigt for at opretholde det faglige niveau. 
Der er på nuværende tidspunkt kun meget få konkrete undersøgelser af uddannelsesteksters sproglige sværhedsgrad (se fx Møller \& Nielsen, 1986). Det var således forventet, at vi måtte indlede denne undersøgelse med at lave en eksemplarisk analyse af læremidler på uddannelsestilbud for u- eller kortuddannede voksne, men det viste sig, at vores projekt blev overhalet indenom af to omfattende danske undersøgelser, der i 20092010 offentliggjorde analyser af læsekrav i forskellige læremidler. Denne ene undersøgelse beskriver læremidler til fire forskellige faglige områder inde for EUD-systemet (Erhvervsuddannelser); nærmere bestemt; nærmere bestemt tekster til uddannelsen som murer, landbrugsassistent og Social- og sundhedshjælper og desuden tekster til grundfaget Samfundsfag, der indgår i alle erhvervsuddannelser (Kabel, Gissel \& Carlsen, 2009; Gissel 2009). Den anden undersøgelse foretager en meget grundig sproglig analyse af læse-/skrivekrav på udvalgte tekster til pædagoguddannelsen (Arnbak, Gandil \& Hauerberg Olsen 2009, Arnbak \& Gandil, 2010).

\subsubsection{Kvalitativ analyse af 4 fagbøger til forskellige erhvervsuddannelser}

I studiet af de fire forskellige læremidler til EUD tages udgangspunkt i en bruttoliste med analysepunkter, der dels knytter sig til tekstens tilgængelighed på tekst-, sætnings- og ordniveau og dels knytter sig til tekstens tilrettelæggelse i forhold til læserens læringsproces. (Kabel, Gissel \& Carlsen, 2009; Gissel, 2009). De fire undervisningsmidler bliver gennemgået ud fra de analysepunkter, der er relevante i forhold til den enkelte tekst og de overordnede pointer i forhold til tekstens læsbarhed. Der er således tale om en semistruktureret analyse med kvalitative eksempler på karakteristiske træk i de enkelte materialer.

Samlet tegner undersøgelsen det klare billede, at fagtekster på erhvervsuddannelser er for svært tilgængelige for målgruppen - uanset fagområde. Undersøgelsen bygger på en kvalitativ vurdering ud fra fokusområder, som kun analyseres, hvis materialet lægger op til det. Det giver en subjektiv arbejdsproces og resulterer i meget forskelligartede konklusioner, som gør det svært at sammenligne analyserne på tværs af fagene. Det er vores opfattelse, at analysemodellen kan anvendes som forarbejde i forbindelse med omskrivninger eller som øjenåbner for interesserede 
fagpersoner med begrænset indsigt i teksters tilrettelæggelse. Derimod kan den ikke bruges som et sikkert vurderingsredskab i forhold til de enkelte faktorer i den sproglige tilgængelighed, og sådan bruges analyserne heller ikke i rapporten.

\subsubsection{Kvantitativ analyse af 15 udvalgte tekster til Pædagoguddannelsen}

I studiet af de 15 udvalgte tekster på Pædagoguddannelsen er der foretaget en kvantitativ analyse af tekstens indholdsmæssige og sproglige tilgængelighed i elementer på tekst-, sætnings- og ordniveau på 17 forskellige parametre (Arnbak m. fl. 2009; Arnbak \& Gandil, 2010).

For hvert af disse analyseområder er der etableret en tretrinsskala med henholdsvis „upåfaldende“, „moderat øget kompleksitet“ og „markant øget kompleksitet". Disse delvurderinger samles til sidst i en samlet vurdering om tekstens tilgængelighed på henholdsvis tekst-, sætnings- og ordniveau.

Analysen af pædagogteksterne er kvantitativ på alle sproglige områder. Det betyder, at man efter analysen kan være sikker på, om der er tale om et gennemgående træk for denne tekst, hvor man i en kvalitativ analyse risikerer at hæfte sig ved påfaldende, men enkeltstående eksempler. På alle sproglige mål er der opstillet faste kriterier for, hvornår teksten vurderes som henholdsvis upåfaldende eller kompleks, ligesom der er opstillet faste grænser for, hvordan den samlede vurdering på henholdsvis tekst-, sætnings- og ordniveau fastlægges på baggrund af delvurderingerne for de enkelte sproglige iagttagelser. Undersøgelsens samlede konklusion er, at studieteksterne på pædagoguddannelsen havde en upåfaldende eller moderat øget kompleksitet på tekstniveau, var upåfaldende på sætningsniveau og havde en markant øget kompleksitet på ordniveau. De mest påfaldende resultater viste sig således på tekstniveau og ordniveau. På tekstniveau var resultatet særligt påfaldende for elementet teksttyper (struktur), hvor der indgik flere teksttyper i samme tekst med varierende abstraktionsniveau. På ordniveau bestod de særligt påfaldende resultater i stort brug af nominaliseringer og høj informationstæthed. Samlet vurderes læsekravene på pædagoguddannelsen til at være høje, og da pædagoguddannelsen tiltrækker relativt mange studerende med læsevanske- 
ligheder sammenlignet med andre tilsvarende uddannelser (Arnbak \& Gandil, 2010) må man forvente, at de nok også er for høje.

Analysemodellen fra studiet af tekster til pædagoguddannelsen har den klare styrke, at vurderingen ikke ender med en simpel angivelse af én samlet vurdering, men er tydeligt opdelt i sproglig tilgængelighed på tekst-, sætnings- og ordniveau med en dertil hørende tredelt vurdering. Endvidere er det en spændende tanke, at alle elementer i tekstanalysen kan kvantificeres, men til gengæld forekommer det som et yderst stort arbejde (og nok også et unødvendigt arbejde), hvis man alene skal vurdere tekstens sværhedsgrad og ikke efterfølgende skal bearbejde teksten.

Det er vores opfattelse, at Arnbak m. fl.'s analyse kan bruges som redskab i forbindelse med sproglig bearbejdning af udvalgte fagtekster, fordi man både opnår en vurdering af generelle tendenser og en detaljeret analyse af hvert enkelt eksempel, som tilsammen kan danne baggrund for en mere hensigtsmæssig udformning af nye materialer. Til gengæld er det vores vurdering, at kriterierne for de kvantitative grænseværdier indtil videre må fremstå som et postulat. Forfatterne fastlægger eksempelvis, at der er tale om markant øget kompleksitet, når $50 \%$ af de grafiske figurer er integreret i brødteksten (på tekstniveau), når 50 \% af perioderne indeholder over 30 ord (på sætningsniveau), eller når der er mere end 2 nominaliseringer pr. periode i et tekstudvalg på $3 \times 300$ ord (på ordniveau). Disse afgrænsninger er sat ud fra forfatternes bedste vurdering, men selvom vurderingen er truffet af kompetente fagpersoner, så er der endnu ingen sikker validering af disse kriterier. I undersøgelsen bad man både undervisere og elever om at vurdere teksternes sværhedsgrad med henblik på en form for ekstern validering, men der var manglende overensstemmelse mellem elever og underviseres vurdering. Der var generelt bedst overensstemmelse mellem undervisernes vurdering og det kvantitative analyseresultat. 
Den teoretiske gennemgang og de konkrete læremiddelsanalyser kan sammenfattes således:

- Fagtekster stiller høje læsekrav

- De analyserede fagtekster var generelt for svært tilgængelige i forhold til deres målgruppe

- En analyse af teksters tilgængelighed bør opdeles på tekst-, sætningsog ordniveau

- På tekstniveau er den sproglige tilgængelighed især påvirket af antallet af forskellige teksttyper i samme tekst og af tekstens evne til at føre læseren gennem tekstens tankerække

- På sætningsniveau er den sproglige tilgængelighed især påvirket af andelen af passivkonstruktioner

- På ordniveau er den sproglige tilgængelighed især påvirket af andelen af nominaliseringer, teksten informationstæthed og andelen af (uforklarede) fagtermer 


\section{Hvad har betydning for faglig læseforståelse?}

På mange punkter er faglig læseforståelse afhængig af de samme færdigheder som forståelse af almene tekster, eksempelvis avisartikler eller narrative tekster (romaner og noveller).

Danske undersøgelser inden for såvel arbejdsmarkedsuddannelser som den pædagogiske grunduddannelse har dokumenteret en stærk sammenhæng mellem deltagernes generelle læseniveau og deres evne til at læse faglige uddannelsestekster inden for deres område (Arnbak,1999; Gellert, 1999). En meget stor del af spredningen på deltagernes faglige læseforståelse kunne således forklares ud fra deltagernes almene læseforståelse (Gellert, 1999). Selvom denne sammenhæng findes, er der nogle særlige forhold ved fagtekster, som kan have betydning for læseforståelsen. Baker (Baker et al, 2002) lister 4 bud på, hvad der kan gøre forståelse af fagtekster særlig vanskelig:

- Fagtekster er oftest meget informationstætte og indeholder ukendte ord, og oftest er indholdet også noget, som læseren ikke har indblik i, men skal til at lære

- Fagtekster er mere komplekse og indeholder mere varierede strukturer, end en narrativ tekst gør. Eksempelvis vil der i fagtekster være figurer, tabeller, faktabokse og punktopstillinger, som læseren skal finde ud af at integrere i tekstlæsningen

- Fagtekster indeholder lange passagerer uden dialog og direkte tale, som læseren er vant til i narrative tekster, og som også er en del af læserens hverdagserfaringer

- For at forstå fagtekster skal læseren kunne forstå de logiske kausale argumenter, som er typiske for fagtekster. Disse er ofte abstrakte og langt fra læserens erfaringsverden og vil derfor være sværere at følge end de kronologiske handlingsforløb, der karakteriserer narrative tekster 
Læseforståelse er en kompleks færdighed, og den afhænger derfor af en lang række sproglige processer. For mere end tyve år siden kom Hoover og Gough med deres bud på en forenklet model over de vigtigste komponenter i læseforståelse. De kaldte modellen for „The simple view of reading“ (Hoover \& Gough, 1990).

\section{Læseforståelse = Afkodning x Sprogforståelse}

Læseforståelse beskrives i modellen som et produkt af afkodning og sprogforståelse. Afkodningen betegner den tekniske side af læsningen, hvor de grafiske tegn bearbejdes, og ordgenkendelse finder sted. Sprogforståelse er de processer, hvor man forstår de enkelte ord og helheder. At læseforståelse beskrives som et produkt af disse to færdigheder, betyder, at begge færdigheder skal mestres, for at man kan opnå god læseforståelse. Hvis man har vanskeligheder med den ene eller begge af disse komponenter, vil man have læseforståelsesvanskeligheder. Ordblinde er karakteriseret ved at have vanskeligheder med afkodningssiden af læsningen, og det er således deres afkodningsfærdigheder, der begrænser deres læseforståelse. Tosprogede med begrænset kendskab til dansk vil ikke som udgangspunkt have problemer med at afkode en tekst, men deres utilstrækkelige ordkendskab vil vanskeliggøre læseforståelsen. Her er det altså sprogforståelsen, der begrænser læseforståelsen.

Man vil måske forvente, at det især er blandt begynderlæsere, at afkodningen kan forklare en stor del variationen i læseforståelse. Imidlertid så man i en dansk undersøgelse med elever i 7. og 8. klasse, at lidt over $20 \%$ af variationen i læseforståelse kunne forklares ud fra elevernes afkodningsfærdighed (Petersen, 2008). Samtidig viste det sig, at $40 \%$ af de elever, der havde læseforståelsesvanskeligheder, også havde afkodningsvanskeligheder. I denne undersøgelse kunne afkodningsfærdigheden forklare samme del af variationen, når man så på læsning af fagtekster (biologi og historie) og på læsning af almene hverdagstekster (avisartikler mm).

Sprogforståelse er en kompleks faktor, der er afhængig af en lang række sproglige processer, hvor man dels skal forstå de enkelte ord og dels skal være i stand til at bearbejde den sproglige information i større enheder på sætnings- og tekstniveau. Ordkendskabet er en central komponent i sprogforståelsen, og læseres ordkendskab har også i en lang række undersøgelser 
vist sig at have stor betydning for læseforståelsen (Perfetti et al, 2005). I den danske undersøgelse med elever i 7. og 8. klasse var ordkendskab således også den faktor, der kunne forklare den største del af variationen i læseforståelse (omkring $40 \%$ af variationen i læseforståelse kunne forklares ud fra elevernes ordkendskab). Tilsammen kunne afkodning og ordkendskab forklare halvdelen af variationen i læseforståelse (Petersen, 2008).

Spørgsmålet er, om læserens ordkendskab og forhåndsviden spiller en større rolle ved læsning af fagtekster end ved læsning af andre tekster. I en undersøgelse med elever på mellemtrinnet sammenlignede McNamara og kolleger, hvilke komponenter der havde betydning for henholdsvis faglig og narrativ læseforståelse (McNamara et al, 2007). I denne undersøgelse viste det sig, at ordkendskabet spillede en større rolle ved faglig læseforståelse end ved forståelse af narrative tekster. Samme forskergruppe har fundet lignende resultater også med ældre elever (McNamara et al, 2007). I en norsk undersøgelse fandt Samuelstuen og Bråten, at gymnasieelevers baggrundsviden om et emne var den faktor, der forklarede mest i variationen af elevernes forståelse af en samfundsfagstekst (Samuelstuen \& Bråten, 2005). Gymnasieelevernes forhåndsviden blev afdækket med en faglig ordkendskabsprøve.

Det samme så man hos Gellert, der undersøgte kursister på den pædagogiske grunduddannelses faglige læsning. Her kunne en yderligere del af variationen i deltagernes læseforståelse forklares ud fra deres faglige ordforråd, selv når der var taget højde for deltagernes almene læseforståelse (Gellert, 1999). Det tyder altså på, at hvis man generelt vil styrke voksnes forudsætninger for at blive gode faglige læsere, så skal man skabe et godt alment læseniveau og en solid faglig baggrundsviden.

Effektiv afkodning og godt ordkendskab er et vigtigt og nødvendigt fundament for god læseforståelse, men disse basale færdigheder gør det ikke alene. Man er også nødt til at beherske mere avancerede sproglige færdigheder for at opnå god læseforståelse. Man har i en række undersøgelser sammenlignet læsere med god og dårlig læseforståelse. I en del af undersøgelserne var læserne matchede på ordkendskab og afkodning, men var karakteriseret ved at have henholdsvis god og dårlig læseforståelse. Disse undersøgelser pegede på 3 områder, hvor eleverne med dårlig læseforståelse klarede sig dårligere end eleverne med god læseforståelse (Perfetti et al, 2005): 
- Evnen til at drage følgeslutninger

- Metakognition - styring og regulering af egen læsning

- Kendskab til forskellige teksttyper

Evnen til at drage følgeslutninger er med til at skabe en sammenhæng i de informationer, teksten giver, fordi man enten integrerer information fra forskellige steder i teksten eller udnytter sin forhåndsviden om emnet (Elbro, 2006). Elever med læseforståelsesvanskeligheder har ofte svært ved at besvare spørgsmål, der kræver, at man drager følgeslutninger, og en undersøgelse viste, at elever med svag læseforståelse havde gavn af, at teksterne blev sprogligt bearbejdet, så det ikke var nødvendigt selv at drage så mange følgeslutninger (McNamara et al, 1996).

Fagtekster er karakteriseret ved at indeholde forskellige typer af tekst i samme tekst. Der er figurer med tekst, der forklarer sammenhænge. Der er faktabokse, der forklarer ord og begreber, og endelig er der overskrifter og punktopstillinger, som kan hjælpe læseren til et bedre overblik over teksten. Christensen undersøgte betydningen af at kende til forskellige teksttyper hos voksne med læsevanskeligheder, der gik på læsekurser. Hun fandt, at omkring $40 \%$ af variationen i de voksnes læseforståelse kunne forklares ud fra deres kendskab til teksttyper (Christensen, 1999). Deltagernes teksttypekendskab blev afdækket med en opgave, hvor de voksne læsere skulle navigere i tekstskabeloner, hvor teksten var erstattet af x'er. Et godt teksttypekendskab er sandsynligvis et resultat af, at man har læst forskellige typer af tekster og gjort sig nogle erfaringer i forhold til, hvordan tekster er bygget op. På den måde kan kendskab til teksttyper måske også ses som et udtryk for læseerfaring.

Unge og voksne med god læseforståelse overvåger deres forståelse (monitorering) og bruger aktivt strategier til at regulere og reparere deres forståelse (Perfetti et al, 2005). De tilpasser deres læsehastighed i forhold til tekstens sværhedsgrad, læser svære afsnit en ekstra gang, stopper op under læsningen og tænker og husker. Disse færdigheder kaldes metakognitive færdigheder. Elever med dårlig læseforståelse er ikke i samme udstrækning aktive, metakognitive læsere (Perfetti et al, 2005). Samuelstuen fandt i sin undersøgelse af norske gymnasieelever, at nogle af eleverne med dårlige afkodningsfærdigheder havde god læseforståelse. Disse elever var karakteriseret ved at havde god baggrundsviden om emnet, men samtidig fortalte 
disse elever også, at de brugte forskellige metakognitive strategier. Fagligt ordforråd forklarede den største del af variationen i læseforståelsen, men herudover bidrog metakognitive strategier signifikant til at forklare yderligere variation (Samuelstuen \& Bråten, 2005).

I forbindelse med en effektundersøgelse vil det være relevant at afdække deltagernes færdigheder på de nævnte områder for at få indblik i deltagernes læseforudsætninger på kritiske områder inden træningen, og for efterfølgende at kunne se, om der er effekt af undervisningen generelt og/eller på et eller flere af disse særlige områder. Samtidig giver det mulighed for at undersøge, om sproglige færdigheder på nogle af de skitserede områder har betydning for, hvor stor eller lille effekt der er af undervisningsforløbet. Således bør man i forbindelse med afdækning af kursisters færdigheder før og efter et træningsforløb afdække følgende:

- Almen og faglig læseforståelse

- Afkodning

- Alment og fagligt ordkendskab

- Kendskab til teksttyper

- Metakognitive strategier 



\section{Undervisning i læseforståelse}

Gennem de senere år har en række effektundersøgelser haft fokus på undervisning i forståelsesstrategier og vigtige færdigheder for læseforståelsen. Man har blandt andet undersøgt effekten af forskellige interventioner på elevernes læseforståelse. I USA blev resultaterne fra effektundersøgelser inden for læseområdet sammenfattet i en stor metaanalyse af National Reading Panel (NRP, 2000). Rapporten sammenfatter således resultaterne fra forskellige effektundersøgelser, og herigennem opnås en øget indsigt i, hvilke færdigheder det især er vigtigt at fokusere på i undervisningen for at opnå positiv effekt på elevernes læseforståelse.

Størsteparten af undersøgelserne i National Reading Panels rapport omhandler elever i grundskolen, og derfor har det amerikanske Institute of Education Sciences bedt førende forskere på området om at lave en sammenfatning af de anbefalinger fra NRP-rapporten, der har særlig betydning for unges læsefærdigheder. Det er blevet til en guide med anbefalinger til, hvordan man bedst arbejder med at forbedre unges læsefærdigheder (IES, 2008). Anbefalingerne til undervisning i læsning bygger på effektundersøgelser med børn og unge. De to første anbefalinger i IESrapporten går på undervisning i ordkendskab og undervisning i forståelsesstrategier. Disse to anbefalinger kan med størst sikkerhed siges at have effekt på elevernes læseforståelse. De to øvrige anbefalinger er der ikke så stærkt belæg for, og de omhandler områder, der ikke har helt så central betydning, når det handler om klasseundervisning i læsning af fagtekster. Den ene anbefaling handler om diskussion og fortolkning, og den anden handler om motivation og holdninger til læsning.

Samlet er IES- rapportens budskab, at der findes specifikke strategier, som underviserne kan anvende til unge læsere. Rapportens anbefalinger skal ikke ses som en fuldstændig liste, men som en samling af de interventioner, der er bedst forskningsmæssigt belæg for, og som indeholder metoder, forskergruppen vurderer velegnede til unge. Metoder, der har vist sig at være effektive i eksempelvis 3. klasse, vil ikke nødvendigvis være en 
farbar vej med unge og voksne. Men eftersom unge- og voksenområdet ikke har haft samme fokus, er der desværre ikke tilstrækkeligt med effektundersøgelser fra ældre elever. Derfor har det været nødvendigt også at skele til, hvad der har vist sig effektivt med yngre elever. Udgangspunktet for nedenstående oversigt er IES-rapporten suppleret med konkrete undersøgelser, der kan belyse nogle af områderne yderligere.

\subsection{Undervisning i ordkendskab}

I starten af skoleforløbet er de fleste af ordene i læseteksterne velkendte for eleverne. Men i løbet af skoletiden bliver teksterne mere komplekse og stiller større krav til elevernes ordkendskab. Især faglig læsning udfordrer elevernes ordkendskab, fordi de inden for de forskellige fag skal lære det pågældende fags ord og begreber for at kunne tilegne sig viden i faget. Forskning har vist, at undervisning i fagligt ordkendskab integreret i faget hjælper de studerende til at forstå det faglige ordforråd i teksterne (Baumann et al, 2003; Bos og Anders, 1990).

IES-rapporten konkluderer med udgangspunkt i 9 forskellige studier, at eksplicit undervisning i ordkendskab har positiv effekt på elevernes ordkendskab. Alle undersøgelserne viser effekt på elevernes ordforråd, men det er kun nogle af dem, der også kan påvise effekt på elevernes læseforståelse (IES, 2008).

Man lærer bedst nye ord ved at møde dem mange gange, men lige præcis det faglige ordkendskab består jo oftest af ord, som er særlige for faget, og det vil derfor ikke være ord, som de studerende støder på andre steder end i det konkrete fag. Dette bevirker, at eleverne ikke præsenteres for ordene så mange gange, og derfor bliver den eksplicitte undervisning i de fagspecifikke ord essentiel (Baumann et al, 2003). 
Men hvad ligger der i begrebet eksplicit undervisning i ordkendskab hvad vil det egentlig sige? Man kan inddele undervisning i ordkendskab i to hovedkategorier:

\section{a. Direkte undervisning i ordenes betydning}

Her undervises eleverne i at slå op i ordbøger og lære at læse og forstå ordbogsdefinitioner. Her arbejdes med specifikke ord, som på forhånd er udvalgt som fokus for undervisningen, og man laver en række aktiviteter med disse ord

b. Undervisning i strategier i at udlede ords betydning af teksten

Her undervises eleverne i at analysere ord morfologisk, kigge efter forklaringer på ordet i teksten og udnytte deres forhåndsviden om emnet

Undersøgelser viser, at begge disse metoder har positiv effekt på ordkendskabet, men på lidt forskellig vis. Baumanns effektundersøgelse sammenlignede effekten af henholdsvis metode a) og metode b) hos elever i 5. klasse. Hans resultater viste, at metode a) er effektiv, hvis det man skal lære betydning af en bestemt række ord, mens metode b) i større udstrækning giver eleverne en strategi, de kan bruge i forskellige sammenhænge i arbejdet med forskellige tekster (Baumann et al, 2003). Så de to metoder supplerer hinanden.

Resultaterne af ordkendskabstrænings effekt på elevernes læseforståelse er ikke entydige (se Baumann 2009 for en oversigt over studier), men mange undersøgelser har vist, at fagligt ordkendskab er essentielt for forståelse af fagtekster. En dansk undersøgelse blandt studerende på pædagogisk grunduddannelse viste, at halvdelen af forskellene i variationen $\mathrm{i}$ deres læseforståelse kunne forklares ud fra forskelle i fagligt ordforråd (Gellert, 1999). Selv når der blev taget højde for variation i almen læseforståelse, kunne forskelle i de studerendes faglige ordkendskab stadig forklare en yderligere del af variationen i den faglige læseforståelse.

Arbejdet med ordforrådet og strategier til tilegnelse af ords betydning har som beskrevet ovenfor været fokus i en række effektundersøgelser. Andre undersøgelser har undersøgt effekten af programmer, hvor eleverne eksplicit blev undervist i forståelsesstrategier, og i mange af disse undersøgelser har man set positiv effekt af en sådan træning på elevernes læseforståelse (NRP 2000 og IES 2008 giver fine oversigter over effektundersøgelser). 
Instruktion i læseforståelsesstrategier består af en række trin (se eksempelvis Rosenshine \& Meister, 1994; Kamil, 2004). Først introduceres strategien for eleverne. Herefter modellerer underviseren strategien, og til slut øver eleverne strategien både sammen med underviseren og på egen hånd (Kamil, 2004). En central målsætning for arbejdet med forståelsesstrategier er, at eleverne bliver aktive forståere. Allerede i 1994 lavede Rosenshine og Meister et review over forskning i reciprok undervisning, som er en betegnelse for en undervisningsmetode i kognitive strategier, man kan bruge i arbejdet med forståelsesstrategier. Et vigtigt princip i reciprok undervisning er, at underviseren modellerer strategierne og tænker højt, mens han/hun gør det. Reviewet fra 1994 viste, at det har positiv effekt på elevernes læseforståelse at arbejde med forståelsesstrategier på denne måde (Rosenshine \& Meister, 1994). Denne metodik har senere ofte været anvendt $\mathrm{i}$ arbejdet med læseforståelsesstrategier (Kamil, 2004).

Forståelsesstrategier er eksempelvis at opsummere, stille spørgsmål, svare på spørgsmål, omskrive og finde hovedtemaet i teksten. Direkte og eksplicit instruktion gives ved modellering, hvor underviseren viser og forklarer eleverne den strategi, som de skal til at lære (se eksempelvis appendix hos Rosenshine og Meister, 1994). Herefter øver eleverne sig og får feedback, og efterfølgende øver eleverne sig på egen hånd.

En række forskellige strategier har været anvendt i det forholdsvis beskedne antal undersøgelser, der opfyldte Institute of Education Sciences (IES, 2008) krav til effektundersøgelser. I de effektundersøgelser, der indgik i analysen, har der været arbejdet med at opsummere hovedpunkter både i afsnit og i hele tekster, stille spørgsmål til det læste, omskrive det læste, drage følgeslutninger med udgangspunkt i tekstens informationer, svare på spørgsmål forskellige steder under læsningen og bruge grafiske modeller til at få overblik over information. Disse strategier ser ud til at være særlig effektive i forbindelse med ældre elever/unge.

IEA-rapporten konkluderer (lige som National Reading Panel konkluderede på baggrund af alle undersøgelserne i metaanalysen) (IES, 2008), at det er svært at fremhæve en strategi frem for andre. Måske er det ikke selve strategien, der giver effekten. Effekten kan skyldes, at eleverne i undervisningen deltager aktivt i forståelsesprocesserne via arbejdet med strategien. De fleste af undersøgelserne sammenligner brug af en eller flere strategier med „traditionel“ undervisning, så det er ikke muligt at sammenligne stra- 
tegierne med hinanden. Det bliver hermed svært at sige, om det ene er bedre end det andet. Men en lille mængde forskning har prøvet at sammenligne forskellige strategier, og her ser det ud til, at træning i at stille spørgsmål, besvare spørgsmål, opsummere og bruge grafiske modeller er særligt effektive strategier at arbejde med. Men det er ikke muligt at sige, hvilken strategi der er den bedste - det kommer til en vis udstrækning an på den tekst, man skal læse (NRP, 2000 og IES, 2008).

Meget tyder på, at det giver bedre effekt at træne flere strategier end at arbejde med en enkelt strategi. Eksempelvis kombinerede en undersøgelse øvelser i at opsummere og i at finde hovedtemaet med god effekt (Katims \& Harris, 1997). Disse resultater stemmer overens med, hvad National Reading Panel konkluderede i deres rapport om arbejdet med læseforståelsesstrategier (NRP, 2000).

I rapporten fra National Reading Panel beskrives også en række studier, hvor man arbejder med at aktivere læsernes forhåndsviden. Arbejdet med at aktivere læserens forhåndsviden har positiv effekt på elevernes læseforståelse, men det er ikke en af de strategier, der isoleret set har størst effekt på elevernes læseforståelse (NRP, 2000). Rapporten fremhæver, at aktivering af forhåndsviden ofte bliver en del af arbejdet med nogle af de andre strategier, eksempelvis arbejdet med stille spørgsmål og besvare spørgsmål til teksten.

Resultaterne fra metaanalyser af læseforståelsestræning giver nogle retningslinjer for, hvordan man kan tilrettelægge en hensigtsmæssig undervisning i læseforståelsesstrategier. Det ser ud til, at det er en god idé at arbejde med forskellige strategier, og især spørgsmålsarbejde, opsummering og brugen af grafiske modeller ser ud til at være effektive metoder med ældre børn og unge (IES, 2008).

En dansk pilotundersøgelse med elever i 8. klasse viste lovende effekter af træning i teksttypekendskab. De elever, der havde modtaget undervisning i bestemte teksttyper (køreplaner og avisartikler), blev bedre til at navigere i disse teksttyper og forstod også teksterne bedre. Der var også en overførselseffekt til teksttyper (pristabeller og fagartikler), der mindede om dem, der blev anvendt i undervisningen (Knudsen, 2003b). Og når Christensen (senere Knudsen) tidligere i en anden undersøgelse har vist, at teksttypekendskab forklarer en stor del af variationen i læseforståelse hos voksne 
med dårlige afkodning, så er det et område, som kunne være relevant at inddrage i et undervisningsforløb for voksne læsere (Christensen, 1999).

I metaanalyserne viste følgende læseforståelsesstrategier sig at være brugbare og effektive i forbindelse med ældre elever (IES, 2008):

- opsummere hovedpunkter både i afsnit og i hele tekster

- stille og besvare spørgsmål (og i den forbindelse aktivere forhåndsviden)

- omskrive og opsummere

- drage følgeslutninger med udgangspunkt i tekstens informationer,

- bruge grafiske modeller

Sammen med resultaterne fra Knudsens pilotundersøgelse i Danmark (Knudsen, 2003) har ovenstående dannet grundlaget for tankerne bag udviklingen af et træningsforløb i dette projekt. Da der i en kontrolleret træningsundersøgelse som denne er begrænset tid til rådighed, er det nødvendigt at foretage et fravalg af de forståelsesstrategier, der endnu ikke er så stærkt belæg for. På den baggrund kan det teoretisk begrundes at fokusere på fire overordnede strategier, der arbejder med følgende områder (se afsnittet Udvikling og opbygning af programmet, LASS SMART):

- fagligt ordkendskab (Lær nye ord)

- teksttyper, grafiske modeller og aktivering af forhåndsviden (Kom i gang)

- stille og besvare spørgsmål (Styr på teksten) og

- opsummere og omskrive indholdet i teksten samt drage følgeslutninger på baggrund af teksten (Husk hvad du læser)

Studierne i metaanalyserne tyder på, at instruktionsmetoder, der kræver meget studenterinvolvering og engagement under læsningen, har positiv effekt på læseforståelse (ISE, 2008). Det er derfor vigtigt at tilrettelægge et undervisningsforløb, hvor læseren udvikler opmærksomhed på de kognitive processer, der indgår i den konkrete strategi, og at underviseren modellerer strategien, så eleverne kan lære at gøre det til deres egen strategi i forbindelse med læsningen. Efterfølgende er det vigtigt, at eleverne får lejlighed til at øve sig i at bruge strategien først sammen med underviseren og senere selvstændigt, så de nye strategier gradvist internaliseres $\mathrm{i}$ elevens arbejde med tekster (Kamil, 2004). 


\section{Formål}

I de foregående afsnit har vi opsummeret central forskningsbaseret viden om voksnes læsefærdigheder, teksters tilgængelighed, faglig læseforståelse og undervisning i faglig læseforståelse. Denne viden dannede grundlag for tilrettelæggelsen og udførelsen af en effektundersøgelse med fagintegreret læseundervisning hos kortuddannede voksne.

Undersøgelsen havde til formål:

- Udvælgelse af en kort arbejdsmarkeds- eller erhvervsuddannelse, hvor skriftsproglige færdigheder spiller en væsentlig rolle i såvel uddannelse som fremtidigt erhverv

- Analyse af læsekravene i denne uddannelse

- at udvikle et konkret undervisningsforløb med udgangspunkt i læsekravene på den valgte uddannelse

- Afprøvning af det udarbejdede undervisningsforløb på den valgte uddannelse

- Evaluering af udbyttet af det gennemførte undervisningsforløb 



\section{Udvælgelse af undervisningssted}

I efteråret 2009 sendte vi en åben invitation til forskellige Arbejdsmarkedsuddannelses- og erhvervsuddannelsescentre på Sjælland for at finde interesserede samarbejdspartnere til vores træningsundersøgelse om fagintegreret læseundervisning på et uddannelsestilbud for u- eller kortuddannede voksne.

På baggrund af den åbne invitation blev vi kontaktet af forskellige interessante uddannelsestilbud, heriblandt HG Kontor. Vi fravalgte ret hurtigt HG Kontor som muligt uddannelsesfelt, da netop en kontoruddannelse lægger op til et større skriftsprogligt fokus, end den primære målgruppe for vores undersøgelse typisk vil have. Vi var med andre ord på udkig efter en uddannelse, der ikke direkte sigtede mod et skriftsprogligt erhverv, men derimod sigtede mod et praktisk arbejdsområde, der bruger skriftlighed i uddannelse og erhverv. Vi fik også kontakt til flere forskellige AMU-centre, og deres kursistprofil svarede til målgruppen for dette studie. AMU-kurserne blev dog i sidste ende valgt fra, fordi vi fandt det umuligt at forene AMU-strukturen med ønsket om et fagintegreret læseundervisningsforløb. AMU-kurser er pr. definition af kortere varighed. De fleste AMU-kurser er endog meget kortvarige (1-2 dage), og de længerevarende arbejdsmarkedsuddannelser på 6-7 uger har hovedvægt på praktiske træningstimer (køretimer på chaufførkurser og lignende). For den enkelte kursist kan flere arbejdsmarkedsuddannelser kombineres i et længerevarende uddannelsesforløb, og i disse forløb kan fx også indgå arbejdsmarkedsuddannelsen „Faglig læsning og skrivning“, men det vil altså i givet fald være som et isoleret uddannelsestilbud ved siden af de øvrige fag. Andre steder tilbyder AMU-centrene Ord- og Talværksteder eller forberedende voksenundervisning (FVU), men igen vil dette være i form af supplerende undervisningstilbud og ikke direkte knyttet til de enkelte fag. 
På et tidspunkt i efteråret 2009 lykkedes det os at få kontakt til SOSU-Greve, et erhvervsuddannelsescenter, der blandt andet uddanner Social- og sundhedshjælpere. Social- og sundhedshjælpere arbejder inden for syge- og hjemmeplejen. Arbejdet kunne tidligere varetages efter et kursus på 9 uger, men kræver nu et væsentligt længere uddannelsesforløb på knap 2 år tilrettelagt som en vekseluddannelse med 3 skoleperioder og 2 mellemliggende praktikperioder. På den måde svarer kursister på Social- og sundhedsuddannelsen til projektets målgruppe, nemlig personer over 18 år, der tidligere kunne varetage jobfunktioner som kort- eller uuddannede voksne, men som nu bliver stillet over for stadig større skriftsproglige krav i såvel (efter)uddannelse som erhverv. Et første afklarende møde viste, at SOSU-Greve havde de nødvendige resurser til at indgå i et projekt som dette. SOSU-Greve har i en årrække været opmærksomme på deres relativt høje andel af læsesvage elever og har forsøgt at løfte de læsesvages kompetencer i løbet af uddannelsen. Som et led i dette arbejde har SOSU-Greve ansat en læsevejleder til at varetage de særlige opgaver, der er forbundet med afdækning, rådgivning og vejledning i forbindelse med læsesvage SOSU-deltagere. På SOSU-Greve har man således screenet kursisternes funktionelle læsefærdighed og fundet, at ca. $60 \%$ af kursisterne har utilstrækkelige funktionelle færdigheder (Kabel, Gissel \& Carlsen 2009). 
Figur 1. Andelen af læsere med utilstrækkelige og gode læsefærdigheder på SOSU Greve i 2009

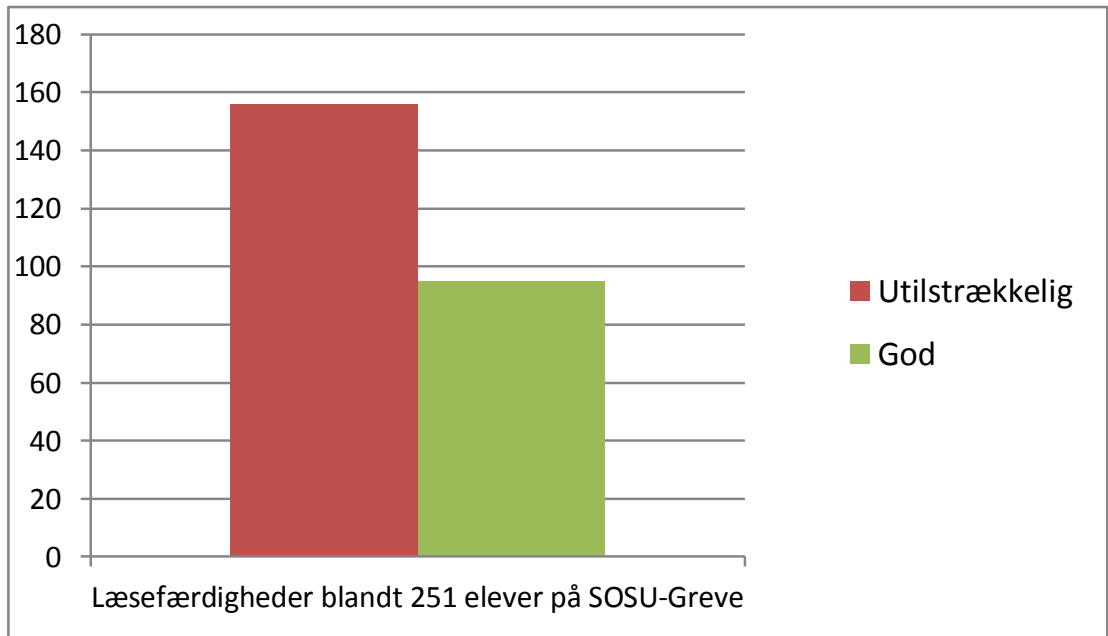

Kabel, Gissel \& Carlsen, 2009

Det er en vigtig forudsætning for et vellykket træningsforløb at have en tovholder på stedet, der tager sig af de daglige spørgsmål og sørger for at viderebringe eventuelle problemstillinger. Derfor var det vigtigt for projektet, at læsevejlederen allerede på det indledende møde fik ledelsens fulde opbakning til at danne bindeled mellem projektgruppen og undervisningsstedet.

Endvidere blev det oplyst, at hovedparten af uddannelsens faglige læsestof findes i grundbogen Social-og sundhedshjælper, der består af 3 bind og dækker alle de fire områdefag, som tilsammen udgør uddannelsens faglige kerne. Grundbogen Social- og sundhedshjælper indgår ikke bare som den primære faglitteratur på SOSU-Greve, men er meget udbredt som grundbog på SOSU i hele landet. SOSU-Greve var et oplagt sted at placere vores træningsundersøgelse, og den skæve kønsfordeling med stor overvægt af kvindelige kursister var umiddelbart den eneste ulempe. Det var fra starten et ønske at placere projektet på et uddannelsessted med ligelig kønsfordeling, men da det ikke lykkedes at finde et interesseret uddannelsessted, der levede op til samtlige projektkriterier, vurderede vi, at det var rimeligt at gå på kompromis med ønsket om en ligelig kønsfordeling. 
I sidste ende valgte vi således Social- og sundhedshjælperuddannelsen som udgangspunkt for vores projektundervisning ud fra følgende begrundelser:

- Der er skriftsproglige krav både i uddannelsen og senere erhverv

- Det er en vekseluddannelse med skiftevis skoleforløb og praktikperiode, hvilket betyder, at man tidligt i uddannelsesforløbet bliver opmærksom på de skriftsproglige krav i det senere erhverv

- Der indgår skriftsprog i de primære arbejdsopgaver

- SOSU er et fagområde, der er blevet voldsomt teoretiseret. Tidligere tiders kursus á 9 ugers varighed er nu blevet et uddannelsesforløb på 1 år og 7 måneder

- Der er fast pensum og et ensartet materialevalg på SOSU-uddannelser i hele landet

- SOSU er et fagområde med mange svage læsere 


\section{Udvælgelse af fagområde til den fagintegrerede læseundervisning}

Udgangspunktet for dette projekt var, at læseundervisningen skulle integreres i et fag på uddannelsen. Ved at lave fagintegreret læseundervisning blev det forhåbentlig mere tydeligt for kursisterne, hvornår og hvordan de skulle bruge det, de lærte i læseundervisningen, end hvis læseundervisningen blev placeret i et isoleret forløb. Ulempen kunne være, at faget „skyggede“ for selve læseundervisningen, og at kursisterne udelukkende fokuserede på det fagfaglige aspekt og ikke blev opmærksomme på, hvordan de strategier, de lærte, også kunne bruges i de øvrige fag.

Et separat undervisningstilbud i læsestrategier vil man ofte placere som en del af læsevejlederens arbejdsområde eller i forlængelse af danskundervisningen. Det vil både skemateknisk og fagligt være lettere at tilrettelægge end et fagintegreret læseundervisningsforløb, der kræver inddragelse af faglærere, som ikke nødvendigvis har arbejdet aktivt med læsestrategier tidligere, og som muligvis vil føle sig fagfagligt presset af også at skulle få tid til læsetræning i undervisningen. Den fagintegrerede undervisning kan enten placeres i et eller flere fag. Hvis den fagintegrerede læseundervisning skal adskille sig fra læseundervisning placeret i supplerende timer, så er det vigtigt, at den er så tæt knyttet til den faglige undervisning som muligt. Den effekt opnår man nemmest ved at knytte undervisningen til et enkelt fag og gerne et fag, som eleverne er så fagligt interesserede i, at den fagintegrerede læseundervisning rammer selve kernen af det faglige indhold, som eleverne skal tilegne sig på uddannelsen. Ved at knytte den fagintegrerede læseundervisning til ét fag, bliver træningsforløbet også knyttet til én underviser pr. hold, mens en undervisning i flere fag vil kræve inddragelse af forskellige undervisere og en indbyrdes koordinering. På lang sigt må perspektivet være, at den fagintegrerede læseundervisning bliver en overordnet undervisningsidé i alle fag (even- 
tuelt efter et indledende fagligt læsekursusforløb), men i forhold til en kontrolleret træningsundersøgelse er det en fordel at knytte undervisningen til ét fag og dermed til én lærer pr. hold. Derfor besluttede vi at udvælge et enkelt fag på SOSU til at danne rammen for den fagintegrerede læseundervisning.

Social- og sundhedshjælperuddannelsen er bygget op omkring 4 områdefag: sundhedsfag, Social- og samfundsfag, pædagogik med psykologi og aktivitets- og praktisk fag. Disse fag repræsenterer Social- og sundhedshjælperuddannelsens fagfaglige indhold, men derudover indeholder uddannelsen også de tre grundfag dansk, engelsk og naturfag samt et enkelt valgfag. En del af undervisningen er organiseret i såkaldte PBL-forløb (ProblemBaseret Læring). Her arbejder eleverne i grupper omkring et tværfagligt emne ud fra en udvalgt case fra deres praktik.

Ved årsskiftet 2009/2010 udarbejdede vi et spørgeskema til henholdsvis lærere og elever på SOSU-Greve som et lille forstudie for at vurdere målgruppens særlige skriftsproglige udfordringer. Lærerne gav i deres besvarelser udtryk for, at elevernes manglende skriftsproglige færdigheder satte begrænsninger i den daglige undervisning. Eleverne gav i deres besvarelser udtryk for, at teksterne i bestemte fag var særligt vanskelige. I nogle af disse fag skyldtes det teksternes sproglige udformning (se afsnittet Fagtekstes tilgængelighed), og i andre fag skyldtes det, at det faglige stofområde var svært tilgængeligt.

På baggrund af spørgeskemaundersøgelsen udvalgte vi et områdefag (sundhedsfag), et grundfag (naturfag) og et PBL-forløb, som vi vurderede nærmere med henblik på at udvælge det fag, der var mest velegnet til et fagintegreret læseforløb. I foråret 2010 observerede vi således 25 undervisningstimer på Social- og sundhedshjælperuddannelsen i Greve med henblik på at udvælge et relevant fagområde og undersøge samspillet mellem tekstlæsning, mundtlig undervisning og de generelle skriftsproglige krav i uddannelsen. Vores observation underbyggede hypotesen om, at SOSUkursisterne havde svært ved at overkomme de skriftsproglige krav i uddannelsen, og at underviserne brugte en stor del af undervisningstiden på mundtligt at formidle det faglige indhold, som eleverne ikke selv kunne tilegne sig gennem tekstlæsning. Det gav i første omgang kursisterne mulighed for at tilegne sig det faglige stof, men på lang sigt begrænser det deres mulighed for at læse sig til faglig viden på egen hånd. 
PBL-forløbet blev udvalgt som observationsfag, fordi det klart var det område, der stillede de største krav til kursisternes selvstændige læsning og skrivning. Efter observationsundervisningen, hvor vi fulgte 2 grupper i deres forløb som en slags flue på væggen, vurderede vi imidlertid, at PBLforløbet ikke var velegnet til struktureret læseundervisning, fordi kursisterne arbejder i selvstændige grupper, hvor de skal udnytte de kompetencer, som de allerede har lært i de enkelte områdefag.

Grundfaget Naturfag blev udvalgt til observationsfag, fordi det var det fag, som de fleste vurderede som et svært fag - både blandt lærere og kursister. Efter observationsundervisningen blev det imidlertid klart, at det helt overordnet var fagets emne, der var svært. Mange kursister på Social- og sundhedshjælperuddannelsen har oplevet faglige nederlag i skolen, og derfor var der hos mange af kursisterne en vis skepsis og negative følelser forbundet med et fag, der indeholder kemi og formler. Det var således ikke den enkelte tekst eller det konkrete emne, men nok så meget selve tanken om faget, der fik eleverne til at reagere. Vi var bange for, at denne generelle usikkerhed over for faget ville påvirke den fagintegrerede læseundervisning i uønsket grad, og derfor fravalgte vi også Naturfag.

Områdefaget Sundhedsfag blev udvalgt som observationsfag, fordi det var det fag, som de fleste elever viste størst faglig interesse for. I løbet af observationsundervisningen blev det tydeligt, at Sundhedsfag var det af de fire Social- og sundhedsfaglige områdefag, som bedst kunne dække den fagteoretiske kerne i Social- og sundhedshjælperuddannelsen. På baggrund af vores observationer ønskede vi at placere den fagintegrerede læseundervisning i et af de fire områdefag, og vi vurderede det som en oplagt fordel at placere træningsforløbet i det områdefag, hvor de fleste elever havde størst interesse i at tilegne sig det faglige indhold. Forventningen var, at interessen for selve faget ville betyde, at kursisterne i større udstrækning kunne se relevansen af det fagintegrerede læseundervisningsforløb, fordi det tog udgangspunkt i tekster, som de var interesserede i at læse og forstå.

På baggrund af lærere og elevers besvarelser af spørgeskemaer i forstudiet samt af vores undervisningsobservation blev Sundhedsfag udvalgt som det fag, hvor den fagintegrerede forsøgsundervisning skulle gennemføres. 



\section{Analyser af fagteksters tilgængelighed på SOSU}

Da Sundhedsfag var udvalgt til den fagintegrerede læseundervisning, skulle de relevante fagtekster analyseres. Det gennemgående læremiddel på Social- og sundhedshjælperuddannelsen har et særligt bind Social- og sundhedshjælper - bind 2, der netop omhandler områdefaget Sundhedsfag. Denne bog var den fælles grundbog og udgjorde størsteparten af fagteksterne i undervisningen. Derfor var det oplagt at benytte denne bog til at beskrive tilgængeligheden af fagteksterne til faget.

Analysen tager afsæt i erfaringerne fra de kvalitative og kvantitative analyser fra undersøgelsen af fagtekster i de fire EUD-fag (Kabel, Gissel \& Carlsen, 2009) og pædagoguddannelsen (Arnbak \& Gandil, 2010). Da SOSU-området indgik som et af de fire EUD-fag med konkrete analyser af Social- og sundhedshjælper - bind 1, blev de kvalitative analyser af denne fagtekst gennemgået særlig grundigt (Gissel, 2009). Gissel har i sin analyse lavet en meget indgående beskrivelse af det Social- og sundhedshjælperbogens tilrettelæggelse i forhold til læserens læringsproces. Vores vurdering er som i Gissels rapport, at der mangler en tilhørende undervisningsvejledning, og at konsekvensen ofte vil være, at grundbogen ikke bruges som det centrale omdrejningspunkt for undervisningen, men i stedet fungerer som en slags opslagsværk.

Udover samspillet mellem tekst og undervisning må man fokusere på, om bogen isoleret set tilrettelægges, så den lever op til principperne for selvstændig tilegnelse af fagligt indhold på skrift (faglig læsning). Man må forvente, at grundbøger formidler det faglige stof på en klar og stringent måde. Derfor vil fokus på analysen af Social- og sundhedshjælper - bind 2 være en vurdering af grundbogens læsbarhed (læsetekniske tilgængelighed). Analysen belyser brugen af henholdsvis automatiske og manuelle vurderingsredskaber på både tekst-, sætnings- og ordniveau. 


\subsection{Automatisk analyse - sproglig varedeklaration}

Forlag, lærebogsforfattere, undervisere og elever ønsker alle, at fagenes grundbøger bliver så let tilgængelige som muligt, uden at det går ud over det faglige indhold. Derfor kunne et oplagt ønske være, at fagbøger påføres en form for sproglig varedeklaration, så man vidste, hvor let eller svært tilgængelig bogen var. Hvis en sådan sproglig varedeklaration skal udbredes i praksis, må der nødvendigvis være tale om ikke bare kvantificerbare mål, men også mål, der kan optælles automatisk.

\subsubsection{Tekstniveau}

Det har ikke været muligt at finde et automatisk måleredskab med en pålidelig vurderingsskala for tekstens tilgængelighed på tekstniveau. Et dansk elektronisk hjælpeværktøj, SprogMagisteren (Christensen m.fl. 1989) anvender forskellige mål for tilgængelighed på tekstniveau. Der anvendes eksempelvis et mål med betegnelsen modtagerappel, som er et kombineret mål for den procentvise andel af personord (som jeg og $d u$ ) og personsætninger (som citater og spørgsmål). Herudover anvender SprogMagisteren forskellige mål for forholdet mellem afsender og tekst, men ingen af disse mål er tydeligt teoretisk begrundet eller anvendt i andre tilsvarende undersøgelser. Det er vores vurdering, at redskabet bør videreudvikles og have en tydeligere teoretisk forankring, hvis det skal udbredes yderligere.

\subsubsection{Sætningsniveau}

Læsbarhedsindex LIX er et udbredt og automatisk vurderingsredskab, der afspejler tekstens sværhedsgrad på ord- og sætningsniveau. LIX kan uden videre bruges i alle nordiske lande, da målet ikke tager udgangspunkt i et konkret ordmateriale. LIX på Social- og sundhedshjælper - bind 2 blev målt til 46,0, hvilket svarer til en „svær tekst“ på vurderingsskalaen for LIX. Analysen af Social- og sundhedshjælper - bind 1 (Gissel, 2009) viste LIX 40 på et meget kort tekstudsnit (926 ord), hvilket svarer til „middelsvær tekst“, men et så lille tekstudsnit gør LIX mere følsomt for konkret ordvalg i netop dette afsnit. LIX-beregningen indgik ikke i vurderingen af de øvrige 
EUD-tekster eller i vurderingen af fagtekster fra pædagoguddannelsen, og derfor kan vi ikke sammenligne med disse tekster. Imidlertid placerer SOSU-bogen sig i den lette ende af „,svær“-kategorien på vurderingsskalaen (grænsen mellem middelsvær og svær tekst er sat mellem 44 og 45), og derfor må det vurderes, at fagbogen til SOSU hverken er lettere eller sværere at læse end andre fagbøger.

\subsubsection{Ordniveau}

Med en vurdering af tekstens informationstæthed (IRate) måles tekstens sværhedsgrad på ordniveau. Den automatiske måling af informationstæthed, IRate, blev foretaget af Peter Juel Henrichsen, der har udviklet en vurderingsskala for informationstæthed på baggrund af IRate og tidligere har udført målingen af informationstæthed på 15 udvalgte fagtekster til undersøgelsen af tekster i pædagoguddannelsen. Informationstætheden, IRate, i Social- og sundhedshjælper - bind 2 blev målt til 87,9, hvilket svarer til „en meget kompakt fagtekst“ med „ekstrem informationstæthed“ på vurderingsskalaen. I undersøgelsen af tekster til pædagoguddannelsen lå samtlige tekster på en IRate mellem 78 og 85, og projektgruppen vurderede, at fagtekster med en IRate på over 80 havde en „markant øget kompleksitet", hvilket i øvrigt var tilfældet for 12 af de 15 fagtekster på pædagoguddannelsen. SOSU-bogen placerer sig over variationen på pædagogteksterne, og det må således vurderes, at fagbogen til SOSU har en lidt højere informationstæthed end fagtekster til pædagoguddannelsen generelt. IRate indgik ikke som vurderingsredskab i analysen af EUD-tekster, og derfor kan informationstætheden i SOSU-bogen ikke sammenlignes med fagtekster fra disse fagområder. Desværre er dette automatiske vurderingsredskab endnu ikke offentligt tilgængeligt, og desuden kræver målet, at teksten holdes op mod et veldefineret ordmateriale. Det betyder, at vurderingsredskabet skal afstemmes efter ordvalget i de enkelte nordiske lande, hvis det på længere sigt skulle udvikles som et tilgængeligt og udbredt vurderingsredskab.

Indtil videre taler vores analyser således for, at en pålidelig automatisk vurdering af tekstens tilgængelighed som en slags sproglig varedeklaration alene kan bygge på en vurdering af LIX og informationstæthed, IRate, 
og at etableringen af et sådant redskab kræver tilpasning til ordmaterialet i de enkelte nordiske sprog.

En sproglig varedeklaration som et hurtigt målredskab vil ganske givet styrke opmærksomheden på fagteksters sproglige kompleksitet, nøjagtig som LIX har været med til at synliggøre begynderlæserens særlige krav til læsbarhed i børnebøger. Omvendt så giver en sådan sproglig varedeklaration ikke en dækkende beskrivelse af teksten, og en sproglige varedeklaration kan umuligt stå alene, hvis man ønsker at arbejde med tekstens tilgængelighed i forbindelse med tekstomskrivning eller læseundervisning.

\subsection{Manuel analyse - sproglige udfordringer ved fagtekster}

Den automatiske analyse tyder på, at Social- og sundhedshjælper - bind 2 på trods af sin høje informationstæthed hverken er sværere eller lettere end fagbøger generelt. Alligevel må det forventes, at tekstens sproglige sværhedsgrad er for høj i forhold til målgruppens læsefærdigheder, og at undervisere og elever må lære at overvinde disse sproglige forhindringer. Hvis lærer og elever skal blive bedre til at klare de sproglige forhindringer, så kræver det, at man synliggør de tekstelementer, der komplicerer tilegnelsen af en fagtekst. Derfor gives der i det følgende afsnit en række eksempler på sproglig kompleksitet på tekst-, sætnings- og ordniveau i en konkret fagtekst. Der indgår ikke en komplet kvalitativ analyse af Socialog sundhedshjælper - bind 2. I stedet udvælges illustrative eksempler fra et opslag i bogen.

\subsubsection{Tekstniveau}

En fagtekst består typisk af flere teksttyper, som skal læses på bestemte måder og med særlige læseformål. Teksteksempel 1 nedenfor er kraftigt nedskaleret, og det ikke er meningen, at det skal læses. Alligevel kan man danne sig et overblik over tekstens emne ved at kigge på overskrifter og overveje, hvad man skal læse om. Man kan også hæfte sig ved punktopstillingen og tegningen på opslaget og overveje, hvordan punktopstillingen med forskellige fordøjelsesorganer evt. kunne hænge sammen med teg- 
ningen af fordøjelseskanalen (placering), og endelig kan man fokusere på de fremhævede hjælpeord i margin.

\section{Teksteksempel 1. Fokus på tekstens opbygning.}

SUNDHEDSFA

\section{Ernæring og fordøjelse}

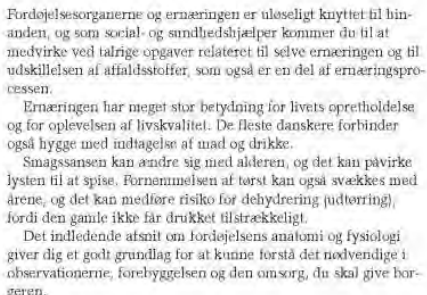
geren.

Fordøjelsens anatomi og fysiologi

Furdejelsesorganerne har til opgave at omdanne fadens neringssioffer fil sà sma dele, at de kan trange gennem larmslimhinden over i blodkarrene og fores ad til alle kroppens celler.

Fordejeisesorganeme omfatter

\begin{tabular}{|c|c|}
\hline $\begin{array}{l}\text { * mundhulen } \\
+ \text { svelget } \\
+ \text { spisereret } \\
+ \text { inavesekken } \\
+ \text { tolvfingertarmen } \\
+ \text { tyndtarmen }\end{array}$ & $\begin{array}{l}\text { + tyktarmen } \\
\text { + endetarmen } \\
\text { samt } \\
\text { spytkirileme } \\
\text { - bugspytkitlen } \\
\text { - leveren }\end{array}$ \\
\hline
\end{tabular}

Fordøjelsesprocessen

Det, vi spiser, bestâr for trinsvis af næringsstofferne protein, fedt og kulliydrat i forskellig mengde og indbyrdes. Forhold. Diss: naringsstoffer findes ofte i foden 1 in form, brot molekylernes for store til at kunne trange germem tarmslimbinden og opsuges
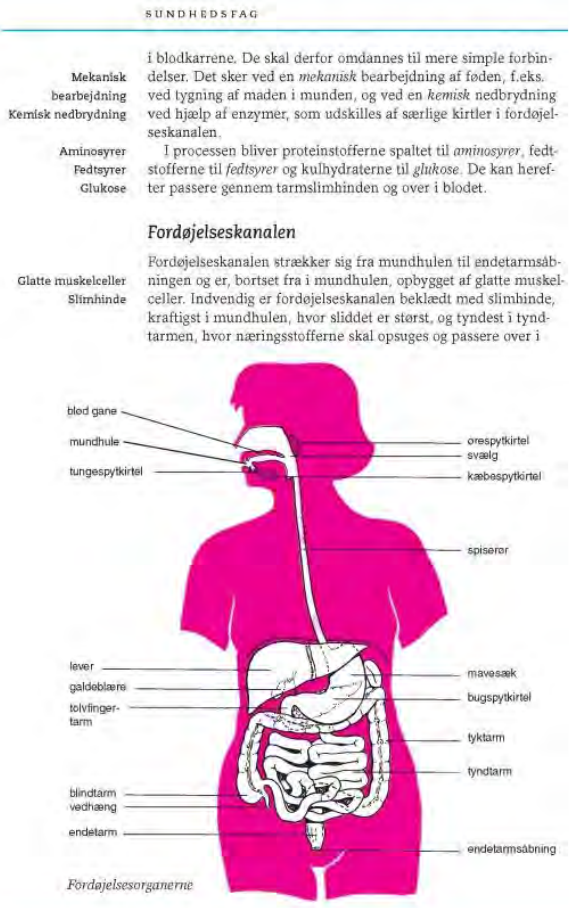

Social-og sundhedshjælper - bind 2, s. 218-219, hvorfra alle teksteksempler er taget.

Teksteksempel 1 er karakteristisk for grundbogen som helhed. Den består af meget brødtekst, og særlige tekstelementer er tydeligt adskilt fra brødteksten. På den måde er det nemt at planlægge sin læserute, og læserens fokus holdes på selve teksten, men omvendt kan det få læseren til at „overse" den supplerende information fra hjælpeord, illustrationer mm. En god tekst sørger for, at overskrifter svarer til brødteksten, og at begreber i en punktopstilling nemt kan overføres til den tilhørende figur eller brødtekst, fx ved hjælp af en særlig skrifttype. I det konkrete eksempel er der ingen tydelig sammengæng mellem begreberne i punktopstillingen på venstre side og begreberne på figuren på højre side, hverken i antallet af 
begreber eller med hensyn til valg af skrifttype, og derved påhviler der læseren en større opgave med at etablere denne sammenhæng.

Det er netop nogle af disse tekstforhold, som er kvantificeret i rapporten om pædagogteksternes tilgængelighed. Her optæller man, hvor mange overskrifter der er dækkende i forhold til brødteksten, hvor mange af de grafiske modeller i teksten der også er beskrevet i brødteksten osv. Vores vurdering er imidlertid, at synliggørelsen har større betydning end den eksakte optælling. Styrken i det daglige arbejde ligger i selve opmærksomheden på at diskutere og skabe den nødvendige sammenhæng mellem brødtekst og tilhørende overskrifter og figurer - uanset om vejen mellem de enkelte tekstelementer i det konkrete tilfælde er kort eller lang.

\subsubsection{Sætningsniveau}

En fagtekst bør skrives i et så let tilgængeligt sprog som muligt, uden at det går ud over den faglige præcision. Derfor bør man generelt forsøge at holde den sproglige kompleksitet på sætningsniveau nede og undgå for mange ledsætninger og ledsætningsniveauer. Til gengæld bør sætningerne ikke blive så korte, at tekstsammenhængen forsvinder, og derfor kan sætninger med tydelige tekstbånd (som men og $d a$ ) virke lettere end korte sætninger med mange punktummer.

Den gennemsnitlige sætningslængde i Social- og sundhedshjælper bind 2 er 18,8 og som tidligere nævnt tyder det ikke på, at sætningerne er mere komplekse end i andre fagbøger. Denne vurdering stemmer overnes med den tilsvarende LIX-måling af Social- og sundhedshjælper - bind 1 (Gissel, 2009). I analysen af fagtekster til pædagoguddannelsen (Arnbak \& Gandil, 2010). bliver det vurderet som markant øget kompleksitet, hvis over $50 \%$ af sætningerne overstiger 30 ord. Det antal kommer Social- og sundhedshjælper - bind 2 slet ikke op på, men naturligvis kan man finde enkeltstående eksempler som Teksteksempel 2, der viser første sætning fra om Ernæring og Fordøjelse. 


\section{Teksteksempel 2. Fokus på sætningslængde}

Fordøjelsesorganerne og ernæringen er uløseligt knyttet til hinanden, og som Social- og sundhedshjælper kommer du til at medvirke ved talrige opgaver relateret til selve ernæringen og udskillelsen af affaldsstoffer, som også er en del af ernæringsprocessen.

Som positive elementer på sætningsniveau fremhæver Gissel i sin kvalitative analyse af Social- og sundhedshjælper - bind 1, at der generelt er en god kohæsion (dvs. sproglig sammenhæng i teksten), og at der bruges ordet „du“ i stedet for fx det mere distancerende „hjælperen“. Teksteksempel 2 illustrerer, at det samme er tilfældet i Social-og sundhedshjælper - bind 2.

De simple sætningsanalyser tyder således på en upåfaldende syntaks, men nominaliseringer og formelt sprogbrug vil ofte indeholde en eller flere skjulte sætninger eller sætningsled, som ikke umiddelbart kan måles på sætningslængden, men som er med til at øge tekstens sproglige kompleksitet - ikke bare på ordniveau. Eksempelvis dækker ordet „relateret“ i Teksteksempel 2 for den skjulte sætning „..., som hører sammen med....,“ mens „ernæringen og udskillelsen“ dækker over „...det at spise noget og det at komme af med.."

På samme måde vil for mange passivkonstruktioner som i Teksteksempel 3 være med til at øge tekstens kompleksitet på sætningsniveau. Vores analyser tyder på, at netop antallet af passivkonstruktioner er relativt højt i Social- og sundhedshjælper - bind 2.

\section{Teksteksempel 3. Fokus på passivkonstruktioner}

Næringsstoffer findes ofte i føden i en form, hvor molekylerne er for store til at kunne trænge gennem tarmslimhinden og opsuges

Vi har ved hjælp af SprogMagisteren målt andelen af passivsætninger til $35,2 \%$, hvilket er et påfaldende højt tal sat op imod Sprogmagisterens norm på 20,8 \% for rapporter og 12,1 \% for almene tekster. De mange passivkonstruktioner nævnes også særskilt som et kritisk element i Gissels analyse af Social- og sundhedshjælper - bind 1. Til sammenligning 
havde kun 3 ud af 15 tekster over $25 \%$ passivkonstruktioner i analysen af pædagogteksterne.

Samlet viser analysen, at sætningskompleksiteten i Social- og sundhedshjælper - bind 2 svarer til niveauet i andre fagtekster, men at en påfaldende stor andel af passivkonstruktioner kan være med til at øge tekstens kompleksitet unødigt. På sætningsniveau kan man med fordel anvende et automatisk vurderingsredskab til at måle fagtekstens læsbarhedsindex, LIX, og eventuelt også andelen af passivkonstruktioner for at vurdere, hvor svær teksten vil være at læse.

\subsubsection{Ordniveau}

I en fagtekst indgår der helt naturligt et antal ukendte fagord. De anvendte fagord er ikke i sig selv et problem, men det kræver, at ordene forklares og anvendes så ofte, at begreberne med tiden føles bekendte. Social- og sundhedshjælper - bind 2 havde en høj informationstæthed, hvilket viser, at bogen benytter relativt mange sjældne ord og gentager dem i relative ringe grad i forhold til andre tekster. En eksemplarisk analyse kan bidrage til forståelsen af, hvordan læremidlet helt konkret introducerer, forklarer og anvender ukendte fagord i teksten.

Som et særligt tekstelement benytter Social-og sundhedshjælper sig i alle tre bind af nøgleord i margin. En samlet gennemgang afdækker, at ordene i margin bruges forskelligt, fx til at fremhæve fagord som i Teksteksempel 4 eller til at opsummere afsnittets indhold. 


\section{Teksteksempel 4. Fokus på hjælpeord i margin}

\begin{tabular}{|c|c|}
\hline $\begin{array}{r}\text { Mekanisk } \\
\text { bearbejdning } \\
\text { Kemisk nedbrydning } \\
\text { Aminosyrer } \\
\text { Fedtsyrer } \\
\text { Glukose }\end{array}$ & $\begin{array}{l}\text { i blodkarrene. De skal derfor omdannes til mere simple forbin- } \\
\text { delser. Det sker ved en mekanisk bearbejdning af føden, f.eks. } \\
\text { ved tygning af maden i munden, og ved en kemisk nedbrydning } \\
\text { ved hjælp af enzymer, som udskilles af særlige kirtler i fordøjel- } \\
\text { seskanalen. } \\
\text { I processen bliver proteinstofferne spaltet til aminosyrer, fedt- } \\
\text { stofferne til fedtsyrer og kulhydraterne til glukose. De kan heref- } \\
\text { ter passere gennem tarmslimhinden og over i blodet. } \\
\text { Fordøjelseskanalen } \\
\text { Fordøjelseskanalen strækker sig fra mundhulen til endetarmsåb- } \\
\text { ningen og er, bortset fra i mundhulen, opbygget af glatte muskel- } \\
\text { celler. Indvendig er fordøjelseskanalen beklædt med slimhinde, } \\
\text { kraftigst i mundhulen, hvor sliddet er størst, og tyndest i tynd- } \\
\text { tarmen, hvor næringsstofferne skal opsuges og passere over i }\end{array}$ \\
\hline
\end{tabular}

I Teksteksempel 4 er de udvalgte fagord i margin ikke defineret i det tilhørende afsnit. Derfor vil man som læser naturligt søge en yderligere ordforklaring i grundbogens stikordsregister, men ud af de syv marginord i teksteksemplet finder man kun ordet slimhinde. Stikordsregisteret henviser i øvrigt ikke til den udvalgte side, men til side 97, hvor ordet ikke forklares, og til side 158 i bogen, hvor ordet forklares. Et godt princip er ellers, at et ord defineres klart, første gang det bruges.

Endelig indgår fagordet enzymer i teksten på Teksteksempel 4. Det optræder ikke i margin, der henvises ikke til ordet i stikordsregisteret, og det defineres ikke her på siden eller på de fire andre sider, hvor ordet forekommer i bogen.

Vurderingerne fra den illustrative gennemgang af Teksteksempel 4 fra Social- og sundhedshjælper - bind 2 svarer til Gissels beskrivelser af eksempler fra Social- og sundhedshjælper - bind 1, og det tyder således på, at de udvalgte eksempler påpeger generelle træk, som gør det svært for læseren at tilegne sig ny faglig viden på egen hånd ved hjælp af dette grundbogsmateriale. Nye fagord kunne introduceres, forklares og anvendes bedre, end tilfældet er. Endvidere burde der være en større sammenhæng mellem ord i stikordsregisteret, fremhævede fagord i testen og udvalgte ord i margin. Endelig kunne stikordsregisteret udbygges, så det ikke kun dækkede det enkelte bind, men indeholdt referencer til relevante kapitler i alle bind. På den måde ville grundbogsmaterialet i højere grad kunne 
anvendes som centralt redskab i hele uddannelsesforløbet - også i de tværfaglige PBL-forløb.

Social-og sundhedshjælperuddannelsen optager elevgrupper, der ikke opfatter sig som „boglige“, samt mange elever med andet modersmål end dansk. Derfor kan det være nødvendigt med særlige sproglige hensyn. Den sproglige tilgængelighed påvirkes ikke kun af de enkelte fagord, men også af de ord og begreber, der bruges i forklaringen af de nye fagord (de såkaldte førfaglige begreber eller gråzoneord).

\section{Teksteksempel 5. Fokus på førfaglige begreber}

Smagssansen kan ændre sig med alderen, og det kan påvirke lysten til at spise. Fornemmelsen af tørst kan også svækkes med årene, og det kan medføre risiko for dehydrering (udtørring), fordi den gamle ikke får drukket tilstrækkeligt.

I Teksteksempel 5 lægges der op til, at fagordet dehydrering skal forklares med ordet udtørring, men forklaringen er ikke tilstrækkelig, hvis man heller ikke kender betydningen af udtørring eller ikke til fulde forstår, hvad det betyder i sundhedsfaglig sammenhæng. Også de førfaglige ord som svækkes og medføre kan skabe problemer og forhindre den fulde forståelse af tekstens indhold. Eksemplet viser, hvor svært det er at være opmærksom på alle de ord, der gør en sætning eller et tekststykke svært at forstå, og at eleverne derfor har brug for generelle værktøjer til at opdage, når og hvad de ikke forstår, og redskaber til at undersøge det ukendte ords betydning.

De konkrete analyser af Social- og sundhedshjælper - bind 2 på tekst-, sætnings- og ordniveau viser, at en sproglig varedeklaration kan være et hurtigt pejlemærke, og at en illustrativ gennemgang af konkrete fagtekster kan være en øjenåbner i forbindelse med udvikling, udvælgelse og revidering af undervisningsmaterialer. Derimod er det svært at se, hvordan disse analyser skal indgå i den daglige undervisning eller tekstlæsning. Hvis man sammenligner de konkrete analyser af fagtekster på tværs af fagområder, så er det påfaldende, hvor ens disse analyser vurderer den sproglige tilgængelighed af fagtekster. Fagtekster er ikke nødvendigvis svære at 
læse på sætningsniveau, men de er svære at lære fra, fordi de indeholder forskellige teksttyper og høj informationstæthed. Det er de særlige kompleksiteter og sproglige forhindringer i fagtekster, som både de kvalitative og de kvantitative analyser forsøger at afdække, men som generelt ikke kan fjernes fra bøgerne. Derfor er det vores vurdering, at en kombination af de eksisterende analyseredskaber er tilstrækkeligt til at give en forståelse for fagteksters kompleksitet, og at der ikke er brug for udvikling af yderligere redskaber til vurdering af fagtekster.

Derimod er der et stort behov for at folde den eksisterende viden om fagteksters kompleksitet ud i den daglige undervisning. Her bør undervisere og kursister i fællesskab arbejde med løbende at opdage særlige elementer eller kompleksiteter i teksten. Når der indgår en figur eller en tabel i teksten, må man til stadighed påpege eller udlede sammenhængen mellem disse tekstelementer. Uanset om der er få eller mange fagord og ukendte begreber i teksten, må man give dem den nødvendige opmærksomhed og gøre, hvad der er nødvendigt for at lære dem.

Der blev foretaget en række automatiske og manuelle sproglige analyser på Social- og sundhedshjælper - bind 2, der er grundbog i Sundhedsfag. Analyserne blev foretaget på tekstniveau, sætningsniveau og ordniveau. Analyserne kan sammenfattes i følgende punkter:

- Et automatisk mål for læsbarhed som en slags sproglig varedeklaration af fagbøger kan udvikles på sætnings- og ordniveau, men ikke på tekstniveau

- Der eksisterer en række anvisninger på manuelle analyser, som kan indgå i en samlet vurdering af fagtekstens tilgængelighed på tekst-, sætnings- og ordniveau. Disse analyser er alle meget tidskrævende og står sjældent mål med den praktiske nytteværdi

- På tekstniveau er grundbogen karakteriseret ved at indeholde meget brødtekst, og de særlige tekstelementer er tydeligt adskilt fra brødteksten. Til gengæld savnes en tydelig forbindelse mellem de særlige tekstelementer og brødteksten

- På sætningsniveau er grundbogen karakteriseret ved at have en stor andel af passivsætninger sammenlignet med fagbøger til andre lignende uddannelser. Herudover er der ingen tegn på, at sætningsstrukturen i denne grundbog er særlig kompleks 
- Grundbogens LIX er målt til 46,0, hvilket svarer til en „svær tekst“ på vurderingsskalaen

- På ordniveau er grundbogen karakteriseret ved en høj informationstæthed med IRate på 87, 9, hvilket svarer til „en meget kompakt fagtekst" på vurderingsskalaen. Fagbøger har generelt en høj informationstæthed, men informationstætheden i denne grundbog er højere end på de analyserede tekster fra pædagoguddannelsen

- En grundig sproglig analyse af grundbogen på tekst-, sætnings- og ordniveau kan bruges i forbindelse med en større sproglig redigering i forbindelse med eventuel genudgivelse

- Denne grundbog er hverken markant sværere eller anderledes opbygget end andre fagbøger. I den daglige undervisning bør man ikke fokusere på at ændre fagtekstens karakteristika. I stedet bør man fokusere på de pædagogiske konsekvenser af fagtekstens karakteristika og lære eleverne at overkomme de sproglige forhindringer 


\section{Udvikling og opbygning af programmet LAES SMART}

Målsætningen var at basere træningsforløbet LÆS SMART på nyere forskningsbaseret viden om, hvordan man bedst arbejder med læseforståelsesstrategier. Eftersom den største del af litteraturen handler om unders $\varnothing$ gelser med børn og unge, var der ikke på forhånd belæg for, at det nyttede at arbejde på denne måde med voksne. Der var et begrænset antal timer til rådighed for programmet, og det nødvendiggjorde en prioritering af, hvilke strategier der skulle arbejdes med. Den afgrænsede tidsramme for projektundervisningen gjorde det vigtigt at fokusere på strategier, som i andre undersøgelser har vist sig at have særlig stor effekt.

LÆS SMART-forløbet er udformet og tilpasset denne undersøgelse, men vil kunne anvendes på andre uddannelser og alderstrin efter en tilpasning af tekstvalget. Forløbet er en konkretisering af strategier i arbejdet med fagtekster, som i andre undersøgelser har vist sig at være nyttige redskaber i dette arbejde (se afsnittet Undervisning i læseforståelse).

Forløbet var for alle strategier inddelt i forskellige faser: Opdelingen er foretaget med udgangspunkt i principper for reciprok undervisning, som de er beskrevet hos en række forskere (Kamil, 2004; Rosenshine og Meister, 1994), men den konkrete inddeling i faser er vores egen.

Introduktionsfase: Her introducerer underviseren strategien og fortæller, hvorfor strategien er nyttig.

Modelleringsfase: Her introducerer underviseren en strategi ved modellering, hvor underviseren viser, hvordan hun selv ville bruge strategien med udgangspunkt i en specifik tekst.

Konsoliderende fase 1 med makkerarbejde: Her bruger kursisterne strategien på en udvalgt tekst sammen med en makker.

Konsoliderende fase 2 med forpligtende selvstændigt arbejde: Her bruger kursisten strategien på tekster efter eget valg i forbindelse med lektielæsningen. Kursisten skal bruge strategien på mindst tre tekster i denne fase. 
Underviseren anbefaler bestemte tekster til dette arbejde, men det står kursisterne frit for at arbejde med andre tekster. I forlængelse af det selvstændige arbejde viser kursisten de udfyldte strategiark frem for underviseren (strategiarkene er afbilledet ved de enkelte strategier på de følgende sider). Her har kursisten mulighed for at få afklaret eventuelle spørgsmål i forbindelse med strategien og for at modtage underviserens respons.

Repetitionsfase: Strategien repeteres i klassen, og her er det kursisterne, der fortæller, hvordan strategien bruges, mens underviseren supplerer.

Implementeringsfase: Her anvender kursisterne strategien som en naturlig del af opgaveløsningen sammen med den næste strategi og som redskab til lektielæsningen i de øvrige fag.

I forløbet arbejdes med 4 forskellige læseforståelsesstrategier, og disse er alle strategier, der i andre undersøgelser har vist positiv effekt på læseforståelsen (se afsnittet Undervisning i læseforståelse). Der blev arbejdet med de 4 strategier ud fra ovenstående faser, og man kom således igennem alle faser med alle strategier. Da strategierne blev introduceret en efter en, blev implementeringsfasen længere med de først introducerede strategier, fordi disse strategier indgik i hele forløbet sammen med de næste strategier. Kursisterne fik altså efterhånden flere og flere strategier, som de skulle øve på teksterne. Formålet med at introducere forskellige strategier var, at kursisterne via forløbet skulle finde ud af, hvilke strategier der var mest brugbare for dem, og forhåbentlig bruge disse efterfølgende i deres uddannelsesforløb. LÆS-SMART forløbet blev afviklet i skoleperiode 2, og bestod af 20 moduler, hvoraf nogle var undervisning, og andre var selvstændigt arbejde med strategierne. Til hver strategi er der udviklet et strategiark, som kursisterne skal anvende ved tekstlæsningen. Udgangspunktet for elevernes arbejde med strategierne er grundbogen i sundhedsfag Social- og sundhedshjælper - bind 2 (Carstensen, Møller og Svanekier, 2009). Nedenfor er en beskrivelse af de 4 strategier: 


\section{Kom i gang}

Formålet med undervisning i denne strategi, som er en „før du læser strategi“, er at vise kursisterne, hvordan man bedst forbereder sig, når man skal i gang med at læse fagtekster.

Størsteparten af kursisterne på SOSU-hjælperuddannelsen har ikke tidligere taget en uddannelse, og de har derfor ikke så mange erfaringer med, hvordan man læser for at lære. Fagtekster er karakteriseret ved at indeholde mange forskellige teksttyper i en, og dette kan gøre dem vanskeligt tilgængelige. En vigtig før-læseaktivitet er derfor at få overblik over, hvilke elementer den tekst, man skal læse, indeholder. Et dansk pilotprojekt i udskolingen har vist positiv effekt af at arbejde med teksttypers karakteristika (Knudsen 2003b), og derfor blev dette arbejde integreret i Kom i gang. Forhåndsviden om et emne har særlig stor betydning for læseforståelsen, når man skal læse og forstå fagtekster (se eksempelvis Samuelstuen \& Bråten, 2005). Derfor er en vigtig læseforberedende aktivitet, at man tuner sig ind på emnet ved at tænke over, hvad man ved i forvejen, så man får etableret en forståelsesramme for tekstlæsningen. Aktivering af forhåndsviden indgik som et element i Kom i gang i håbet om, at kursisterne via dette arbejde fik implementeret denne metode i deres selvstændige lektielæsning.

I denne strategi arbejder kursisterne således med, hvordan de kigger på tekstens struktur, før de går i gang, og aktiverer deres forhåndsviden om emnet. Via arbejdet i Kom i gang bliver kursisterne opmærksomme på følgende:

- Hvad handler teksten om? (overskriften)

- Hvad ved jeg allerede om dette emne? (baggrundsviden)

- Hvordan kan teksttype, overskrift, marginord og illustrationer fortælle, hvad teksten omhandler? 
Figur 3. Kom i gang - øveark

\section{Kom i gang}

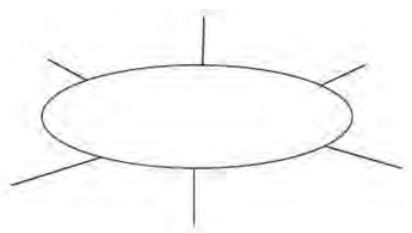

\section{Lær nye ord}

Formålet med undervisning i denne strategi, som er en „mens du læser strategi“, er at skærpe kursisternes opmærksomhed på nye ord og give dem strategier, de kan bruge i jagten på ordets betydning.

Når man starter på en uddannelse, skal man til at lære et nyt fagsprog til de forskellige fag i uddannelsen, så derfor er det i høj grad relevant at fokusere på det faglige ordforråd, da dette har stor betydning for den faglige læseforstålse (se eksempelvis Gellert, 1999). Derfor blev ordkendskab et helt centralt fokusområde. Arbejdet med det faglige ordkendskab i LÆS SMART er en kombination af de to tidligere beskrevne metoder: metode (a) Direkte undervisning $\mathrm{i}$ ordenes betydning og metode (b) Undervisning i strategier $\mathrm{i}$ at udlede ords betydning af teksten (se afsnittet Undervisning i læseforståelse).

Kursisterne skulle lære, hvilke informationer de kunne finde om ordet ved at se nærmere på ordet, se i teksten og ved at anvende ordbog. Afslutningsvis skulle kursisterne skrive deres egen forklaring på ordet. At forklare ordet med egne ord har i en række undersøgelser vist sig at have positiv effekt på ordkendskabet, og metode a) er særlig effektiv, når et nyt fagsprog skal læres, mens metode b) i større udstrækning styrker kursisternes færdigheder $\mathrm{i}$ at finde frem til ords betydning via informationer i teksten (Baumann, 2003). Der var ikke et fast ordmateriale til denne del af træningen, men de studerende skulle selv vælge, hvilke ord de ville arbej- 
de med. Det skulle skærpe deres opmærksomhed på, om de forstod betydningen af de anvendte fagudtryk, og forhåbentlig gøre strategien til en del af deres aktive læsning af fagtekster.

Ordmaterialet i modelleringsfasen var relevante ord fra sundhedsfag. Via dette arbejde blev der samtidig sat fokus på elevernes faglige ordforråd og begrebsverden. Udgangspunktet for arbejdet med ordene var et strategiark, hvor kursisterne skulle fortælle, hvilke informationer de kunne få om ordets betydning ved at kigge på ordet, kigge på teksten og kigge andre steder i bogen efter supplerende informationer om ordet, inden de med egne ord skulle gengive ordets betydning. På den måde skulle de bevidstgøre sig om, hvilket udbytte arbejdet med ordet havde givet.

Figur 4. Lær nye ord - øveark

\section{Lær nye ord}

Skriv ordet

Kig på ordet

Les rundt om ordet

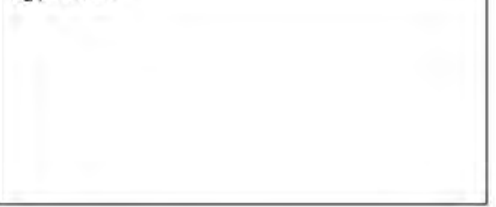

Led efter ordet

Forklar med egne ord

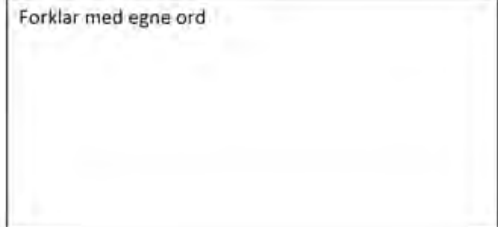

\section{Styr på teksten}

Formålet med undervisning i denne strategi, som er en „efter du har læst strategi“, er at give kursisterne et redskab til at få overblik over indholdet i teksten. Kursister arbejder med at stille spørgsmål til teksten, efter de har læst den. 
Metaanalysen med fokus på unge læsere viste, at arbejdet med at stille spørgsmål til teksten er en af de metoder, hvor man kunne se bedst effekt på læseforståelsen (se afsnittet Undervisning i læseforståelse). Derfor var der ingen tvivl om, at arbejdet med at stille spørgsmål til teksten skulle være et af elementerne i programmet.

I modelleringen af denne strategi illustrerede underviseren, hvordan overskrifter i teksten og nye fagord kan være udgangspunkt for, hvilke spørgsmål det er hensigtsmæssigt at stille, så svarene på de stillede spørgsmål bliver en opsummering af tekstens indhold.

Figur 5. Styr på teksten - øveark

\section{Styr på teksten}

Spørg

Svar

\begin{tabular}{|l|l|}
\hline 1. & \\
\hline 2. \\
\hline 3. \\
\hline 4. & \\
\hline 5. & \\
\hline
\end{tabular}

\section{Husk hvad du læser}

Formålet med undervisning i denne strategi, som er en „efter du har læst strategi“, er at give kursisterne redskaber, der kan hjælpe dem til bedre at huske teksten.

Metaanalysen med fokus på unge læsere viste, at undervisning og træning i at opsummere tekstens indhold havde god effekt på elevernes læseforståelse (se afsnittet Undervisning i læseforståelse). Derfor blev opsummering et centralt element i „Husk hvad du læser“. Et andet element, der også indgik i arbejdet med denne strategi, var at drage følgeslutninger. Kursi- 
sterne skulle med udgangspunkt i det læste drage slutninger om, hvordan de selv kunne bruge den erhvervede viden. Arbejdet med opsummering og følgeslutninger blev organiseret, så kursisterne efter læsningen skulle skrive, hvad de skulle lære, hvad de havde lært, og hvordan de kunne bruge denne viden som SOSU-hjælpere. Strategiarket skulle bruges sammen med et eller flere af de øvrige strategiark efter kursistens eget valg. Forhåbningen var, at kursisterne overvejede, hvilke strategiark de især fandt nyttige, så de især kunne anvende dem fremover.

\section{Figur 6. Husk hvad du læser - øveark}

\section{Husk hvad du læser}

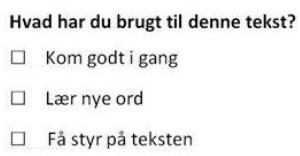

Hvad skulle du lære af denne tekst?

Forklar hvad du lærte:

Hvordan skal du bruge den nye viden som SOSU-hjælper?

I oversigten figur 7 kan man danne sig et overblik over, hvordan LÆS SMART-forløbet blev afviklet. Til hver af de fire strategier indeholder LÆS SMART-forløbet 5 træningsmoduler, som placeres i tilknytning til fagundervisningen i Sundhedsfag. Træningsmodulerne efterfølges af en implementeringsfase, hvor strategierne anvendes i alle fag. Det giver i alt 20 træningsmoduler efterfulgt af en individuel implementeringsfase af forskellige varighed og intensitet. 
Figur 7. Oversigt over elementerne i LAES SMART.

\begin{tabular}{|c|c|c|c|c|}
\hline & $\begin{array}{l}1 . \\
\text { Kom i gang }\end{array}$ & $\begin{array}{l}2 . \\
\text { Lær nye ord }\end{array}$ & $\begin{array}{l}3 . \\
\text { Styr på teksten }\end{array}$ & $\begin{array}{l}4 . \\
\text { Husk hvad du læser }\end{array}$ \\
\hline Modelleringsfase & $\begin{array}{l}\text { Underviseren } \\
\text { modellerer Kom i } \\
\text { gang med en } \\
\text { tekst fra sund- } \\
\text { hedsfag. }\end{array}$ & $\begin{array}{l}\text { Underviseren } \\
\text { modellerer Lær } \\
\text { nye ord med en } \\
\text { tekst fra sund- } \\
\text { hedsfag. }\end{array}$ & $\begin{array}{l}\text { Underviseren } \\
\text { modellerer Styr } \\
\text { på teksten med } \\
\text { en tekst fra } \\
\text { sundhedsfag. }\end{array}$ & $\begin{array}{l}\text { Underviseren model- } \\
\text { lerer Husk hvad du } \\
\text { læser med en tekst fra } \\
\text { sundhedsfag. }\end{array}$ \\
\hline $\begin{array}{l}\text { Konsoliderende fase } \\
\text { med selvstændigt } \\
\text { arbejde }\end{array}$ & $\begin{array}{l}\text { Kursisterne } \\
\text { bruger Kom i } \\
\text { gang-arket } \\
\text { minimum } 3 \\
\text { gange ved } \\
\text { læsning af } \\
\text { fagtekster. }\end{array}$ & $\begin{array}{l}\text { Kursisterne } \\
\text { bruger både Kom } \\
\text { i gang og Lær nye } \\
\text { ord-arket mini- } \\
\text { mum } 3 \text { gange ved } \\
\text { læsning af } \\
\text { fagtekster. }\end{array}$ & $\begin{array}{l}\text { Kursisterne } \\
\text { bruger både Kom } \\
\text { i gang, Lær nye } \\
\text { ord og Styr på } \\
\text { teksten-arket } \\
\text { minimum } 3 \text { gange } \\
\text { ved læsning af } \\
\text { fagtekster. }\end{array}$ & $\begin{array}{l}\text { Kursisterne bruger } \\
\text { Husk hvad du læser- } \\
\text { arket sammen med et } \\
\text { eller flere af de øvrige } \\
\text { ark minimum } 3 \text { gange } \\
\text { ved læsning af fagtek- } \\
\text { ster. }\end{array}$ \\
\hline Repetitionsfase & $\begin{array}{l}\text { Repetition og } \\
\text { evaluering. } \\
\text { Fælles gennem- } \\
\text { gang, hvor } \\
\text { kursisterne viser, } \\
\text { hvordan man } \\
\text { bruger Kom i } \\
\text { gang på en } \\
\text { udvalgt tekst fra } \\
\text { sundhedsfag. } \\
\text { Underviseren } \\
\text { supplerer. }\end{array}$ & $\begin{array}{l}\text { Repetition og } \\
\text { evaluering. Fælles } \\
\text { gennemgang, } \\
\text { hvor kursisterne } \\
\text { viser, hvordan } \\
\text { man bruger Lær } \\
\text { nye ord på en } \\
\text { udvalgt tekst fra } \\
\text { sundhedsfag. } \\
\text { Underviseren } \\
\text { supplerer. }\end{array}$ & $\begin{array}{l}\text { Repetition og } \\
\text { evaluering. Fælles } \\
\text { gennemgang, } \\
\text { hvor kursisterne } \\
\text { viser, hvordan } \\
\text { man bruger Styr } \\
\text { på teksten på en } \\
\text { udvalgt tekst fra } \\
\text { sundhedsfag. } \\
\text { Underviseren } \\
\text { supplerer. }\end{array}$ & $\begin{array}{l}\text { Repetition og evalue- } \\
\text { ring af Husk hvad du } \\
\text { læser og hele LAES- } \\
\text { SMART forløbet. } \\
\text { Fælles gennemgang, } \\
\text { hvor kursisterne viser, } \\
\text { hvordan man bruger } \\
\text { strategierne på en } \\
\text { udvalgt tekst. } \\
\text { Underviseren supple- } \\
\text { rer. }\end{array}$ \\
\hline Implementeringsfase & $\begin{array}{l}\text { Kom i gang-arket } \\
\text { bruges i de } \\
\text { efterfølgende } \\
\text { konsoliderende } \\
\text { faser med } \\
\text { selvstændigt } \\
\text { arbejde. }\end{array}$ & $\begin{array}{l}\text { Lær nye ord-arket } \\
\text { bruges i de } \\
\text { efterfølgende } \\
\text { konsoliderende } \\
\text { faser med } \\
\text { selvstændigt } \\
\text { arbejde. }\end{array}$ & $\begin{array}{l}\text { Styr på teksten- } \\
\text { arket bruges i de } \\
\text { efterfølgende } \\
\text { konsoliderende } \\
\text { faser med } \\
\text { selvstændigt } \\
\text { arbejde. }\end{array}$ & $\begin{array}{l}\text { Husk hvad du læser og } \\
\text { de øvrige tre strategi- } \\
\text { ark bruges i de } \\
\text { efterfølgende konso- } \\
\text { liderende faser med } \\
\text { selvstændigt arbejde. }\end{array}$ \\
\hline
\end{tabular}


Udgangspunktet var, at kursisterne efterfølgende skulle bruge de fire strategiark i resten af deres uddannelsesforløb. Denne fase er ikke en del af selve træningsforløbet, men kursisterne fik udleveret supplerende strategiark, som de kunne kopiere og bruge efter behov. Arbejdet med strategiark 4 - Husk hvad du læser, hvor de øvrige strategiark var inkluderet og kunne bruges efter eget valg, skulle være en forberedelse til dette. LÆS SMART-forløbet kan samles i følgende punkter:

- Der blev udviklet et program, så kursisterne skulle arbejde med læseforståelsesstrategier i Sundhedsfag

- Træningen bestod af 4 strategiark og en tilhørende undervisningsvejledning

- Der indgik fire forskellige hovedelementer i træningen en „før-læse strategi“, en „mens-du læser strategi“ og to „efter du har læst strategier". Disse strategier blev udvalgt på baggrund af metaanalyser om effektive metoder til undervisning i læseforståelse

- I programmet arbejdede kursisterne med teksttypekendskab, aktivering af forhåndsviden, ordkendskab, træning i at stille og besvare spørgsmål til teksten, opsummering og med at drage følgeslutninger

- Arbejdet med samtlige strategier blev tilrettelagt på samme måde. Hver enkelt strategi blev først introduceret, herefter modellerede underviseren, så arbejdede underviser og kursister sammen om at bruge strategien, så trænede kursisterne strategien med en makker, og endelig trænede kursisten strategien selvstændigt, inden strategien afslutningsvis blev repeteret på holdet og derefter indgik som en integreret del af kursistens egen læseviden 



\section{Deltagere og unders $\emptyset$ gelsesdesign}

Undersøgelsens deltagere var kursister og undervisere på SOSUhjælperuddannelsen i Greve. I alt 139 kursister deltog i træningsunders $\varnothing$ gelsen. Kursisterne var fordelt på 4 forskellige hold. 2 af holdene modtog den sædvanlige læsestrategiundervisning, som skolens læsevejleder varetog, og de 2 andre hold deltog i det særlige træningsforløb, LÆS SMART.

Læsevejlederens undervisning var organiseret som et separat forløb ved kursisternes uddannelsesstart og foregik i dansktimerne. På læsevejlederens kursus blev kursisterne bevidstgjort om vigtigheden af at have et læseformål, vælge en hensigtsmæssig strategi og efterfølgende evaluere deres læsning. Her blev blandt andet arbejdet med VØL-modellen, hvor læseren skal aktivere forhåndsviden, stille forventninger til teksten samt efterfølgende sammenfatte og evaluere læseudbyttet. Der blev også arbejdet med ordkort, som kursisterne kunne bruge til ord, hvor de var usikre på betydningen. Efterfølgende blev kursisterne tilbudt supplerende kurser i faglig læsning, men disse lå om eftermiddagen uden for almindelig undervisningstid og var på frivillig basis.

I LÆS SMART-forløbet var undervisningen i læsestrategier en integreret del af undervisningen i Sundhedsfag (se afsnittet Udvikling og opbygning af programmet, LESS SMART). I det fagintegrerede læseforløb blev der arbejdet med en række forskellige forståelsesstrategier med udgangspunkt i tekster fra kursisternes grundbog i Sundhedsfag.

Kursisternes færdigheder blev afdækket 2 gange inden træningsforl $\varnothing$ bet og 2 gange efter træningsforløbet. De 4 prøvegange var placeret, så første gang var omkring uddannelsesstart, anden gang umiddelbart inden træningsforløbet, tredje gang umiddelbart efter afslutningen på træningsforløbet og fjerde gang ved uddannelsens afslutning. Ud over diverse prøver og spørgeskemaer fik vi adgang til kursisternes fraværsprocent og oplysning om, hvorvidt kursisten havde gennemført uddannelsen på nor- 
meret tid, havde forlænget uddannelsen eller havde afbrudt uddannelsen uden at færdiggøre den. Ved første og fjerde testgang var fokus afkodning, almen læseforståelse og læsestrategier, altså almene funktionelle læsefærdigheder. Ved anden og tredje gang var der særligt fokus på faglig læsning og kendskab til teksttyper. Desuden besvarede kursisterne spørgeskemaer ved uddannelsens start og afslutning, og LÆS-SMARTkursisterne besvarede yderligere et spørgeskema, hvor de evaluerede træningsforløbet. Af de 139 kursister var 133 med fra starten, mens de sidste $6 \mathrm{kom}$ til i løbet af projektet, fordi de skiftede hold på grund af studieforlængelse. 43 kursister deltog i alle testgange, 35 kursister (25\%) afbrød deres uddannelse og 11 (8\%) flyttede til andre hold og færdiggjorde derfor uddannelsen på et senere tidspunkt. Herudover var der kursister, der ikke deltog i alle prøvegange, fordi de ikke var mødt til undervisning de dage, hvor prøverne blev afviklet. Der er lavet envejs-variansanalyser (Oneway ANOVA) for at se, om kursister, der deltog i alle testgange, havde bedre eller dårligere færdigheder end dem, der kun deltog i nogle testgange. Der var ikke signifikant forskel på de to grupper på nogen af målene. Så selvom vores analyser bygger på en langt mindre del af kursisterne, end vi havde håbet på, så er der altså ikke noget, der tyder på, at disse kursister er anderledes end de øvrige kursister på uddannelsen.

Kønsfordelingen på uddannelsen er meget skæv. $82 \%$ af kursisterne er kvinder, og samtidig er frafaldet signifikant større blandt de mandlige kursister. Således afbrød $44 \%$ af de mandlige kursister uddannelsen sammenlignet med $20 \%$ af de kvindelige kursister. 


\section{Prøver i unders $\varnothing g e l s e n$}

\subsection{Læseforståelse}

For at få et bredt indblik i elevernes læseforståelse anvendtes to forskellige læseforståelsesprøver, en almen læseforståelsesprøve og en faglig læseforståelsesprøve. De anvendte læseforståelsestests afdækker elevernes funktionelle læseforståelse, og prøveteksterne er autentiske hverdags- og fagtekster.

\subsubsection{Læsetekster for unge og voksne}

Læsetekster for unge og voksne består af tre forskellige typer af tekster, opslagstekster (tv-program, telefonbog, kort og oversigter), informerende tekster (opskrift, brugervejledninger, information fra offentlige instanser) og fortællende tekster (korte og lange avisartikler). Der er i alt 60 multiple choice spørgsmål til teksterne (20 til hvert delområde). Eleverne får 15 minutter til hver af de tre delområder. I løbet af denne tid skal kursisterne læse teksterne og besvare de tilhørende spørgsmål. Prøven har tidligere været anvendt i en række forskellige forskningsprojekter og bruges også på mange uddannelser til at afdække elevernes færdigheder ved studiestart. På SOSU-Greve blev materialet således allerede brugt ved studiestart som en fast iagttagelsesprocedure. I indeværende undersøgelse blev materialet både brugt ved studiestart og ved afslutning på uddannelsen. Kursisternes resultat på denne prøve bliver beskrevet som deres almene læseforståelse. Da denne prøve har været anvendt i en lang række undersøgelser, er opgaven ikke analyseret på itemniveau, men i vejledningen til materialet er angivet en reliabilitetskoefficient (Cronbachs alfa $=0,92$ ) (Arnbak, 2001). 


\subsubsection{Faglig læsning, historie og biologi}

Her anvendtes en faglig læseprøve, der er udformet til og anvendt i folkeskolens ældste klasser (Petersen, 2008). Dette skulle sikre, at den ikke blev oplevet som umulig af kursisterne, og samtidig gav det mulighed for at sammenligne kursisternes resultat med disse elevers resultat. Den faglige læseforståelsesprøve bestod af to delprøver. Der var en historietekst med 19 tilhørende multiple-choice spørgsmål og en biologitekst ligeledes med 19 tilhørende multiple-choice spørgsmål. Eleverne havde til hver delprøve 16 minutter til læsning af tekst og besvarelse af spørgsmål. Teksterne til de faglige læseprøver er hentet fra undervisningsmaterialer beregnet til 7. og 8. klassetrin (Berthelsen, 1994; Brinckmann et al, 1997). Elevernes resultater på disse prøver bliver beskrevet som deres faglige læseforståelse i biologi og historie (Reliabilitet Cronbachs alfa biologi: 0,79 , historie: 0,85 ).

\subsection{Ordkendskab}

\subsubsection{Alment ordkendskab}

I den almene ordkendskabsprøve var opgaven at vælge det ord blandt tre mulige, der betød det samme som eksempelordet. De tre ord, eleverne skulle vælge imellem, var betydningsmæssigt beslægtede. Eksempelvis sagde testtageren: Lille gulerod - er det "squash" , „artiskok“ eller ",karotte“? Eleverne skrev deres svar på en tipskupon, og der var i alt 25 opgaver (Reliabilitet Cronbachs alfa 0,76). Elevernes resultat på denne prøve bliver beskrevet som deres almene ordkendskab, og denne prøve har tidligere været anvendt i en undersøgelse med de ældste elever i folkeskolen (Petersen, 2008). I den almene ordkendskabsprøve indgik ikke ord fra Sundhedsfag, da der til undersøgelsen var udviklet en specifik faglig ordkendskabsprøve til dette fagområde. På den måde blev det muligt at se på forholdet mellem elevernes almene og faglige ordkendskab. 


\subsubsection{Sundhedsfagligt ordkendskab}

Den faglige ordkendskabsprøve var udformet efter samme skabelon som den almene ordkendskabsprøve, men her var ordene hentet fra det sundhedsfaglige område. Sundhedsfagligt ordkendskab bestod af 30 opgaver, eksempelvis sagde testtageren: Alzheimer - er det „,sygdom “ , ,lægemiddel“ eller „, undersøgelsesmetode"? Elevernes resultater på denne prøve bliver beskrevet som deres sundhedsfaglige ordkendskab (reliabilitet Cronbachs alfa 0,88). Ingen af ordene i denne ordkendskabsprøve indgik i biologiteksten.

\subsection{Afkodning}

\subsubsection{Find det ord der er rigtigt stavet}

Prøven indeholder 113 opgaver og afdækker elevernes genkendelse af ordbilleder/stavemønstre. Prøven er en forlænget version af den oprindelige test „Find det ord, der er rigtigt stavet“ (Nielsen og Petersen, 1992). Den lange udgave blev i sin tid udviklet til et projekt om læseforståelse i folkeskolens ældste klasser (Petersen, 2008). I hver opgave skulle eleverne afgøre, hvilket af 4 ord/nonsensord der er et rigtigt ord. Alle ord lyder ens, hvis man udtaler dem, så opgaven kan ikke løses alene ved at give hvert bogstav en lyd (se figur 8). Eleverne fik to minutter til opgaven. Testen har i tidligere undersøgelser vist høj reliabilitet (Cronbachs alfa 0,97) i en undersøgelse af handelsskoleelevers læsning (Gellert, ej publiceret). Elevernes resultat på denne prøve bliver beskrevet som deres afkodningsfærdighed.

Figur 8. Eksempel på opgave fra ,Find det ord, der er rigtigt stavet"

fætter fedder fædder fetter

\subsubsection{Viden om teksttyper}

Her afdækkes elevernes kendskab til forskellige teksttyper. Der blev til denne undersøgelse udviklet to forskellige prøver til afdækning af elevernes kendskab til teksttyper, en almen og en sundhedsfaglig. Prøverne er udviklet efter samme skabelon som en tidligere anvendt teksttypeprøve til 
voksne (Knudsen, 2003). I forbindelse med et ph.d. projekt er der udviklet en tilsvarende teksttypeprøve til mellemtrinnet, og denne adskiller sig fra Knudsens ved at have flere spørgsmål til de enkelte tekster (Rønberg og Petersen, 2011). Prøven til SOSU-kursisterne er inspireret af begge disse prøver. I alle tekster er bogstaverne erstattet af x'er, så tekstopsætningen bevares, men teksten bliver uden indhold. Elevernes opgave er at sætte en streg til det sted, hvor man kan forvente at finde en bestemt information $\mathrm{i}$ en given tekst. Opgaven kan ikke løses ved læsning, da teksten udelukkende består af x'er. Opgaven må besvares med udgangspunkt i elevernes viden om, hvordan forskellige teksttyper er opbygget. De to prøver består af hver fem forskellige „tekster", og der indgår samme teksttyper i almen og faglig form i de to prøver. Der var 5 spørgsmål til hver tekst., dvs. 2x25 spørgsmål i alt. Spørgsmålene skulle afdække, om eleverne vidste, hvor en bestemt information fandtes i den pågældende tekst. Alle opgaver var samlet i et hæfte, og eleverne fik 10 minutter til hver af de to delprøver (almene tekster og sundhedsfagstekster).

Figur 9. Teksttypekendskab, eksempelopgaven

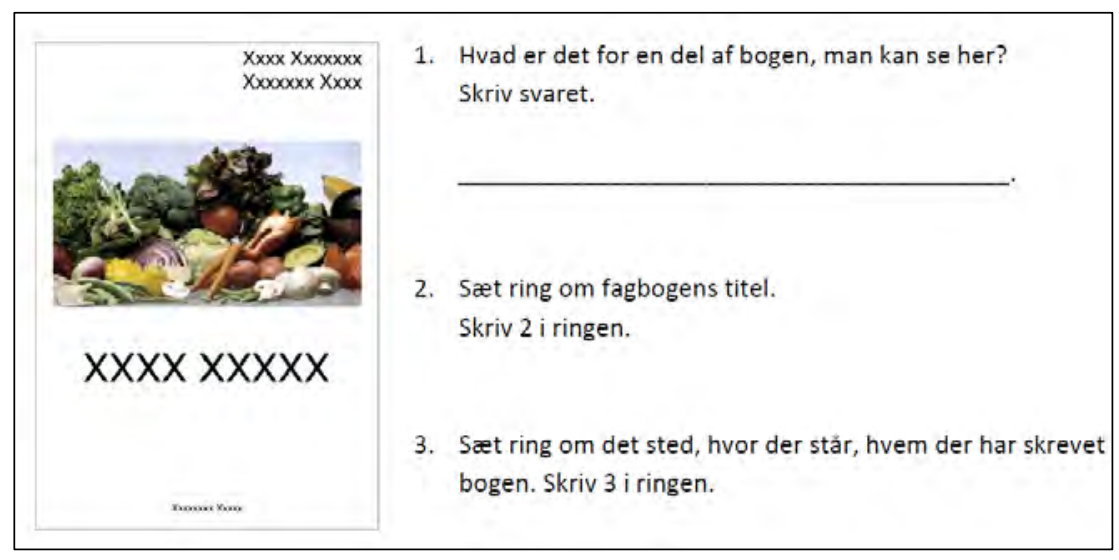


Oversigt over delopgaver i „Viden om almene teksttyper“ (25 opgaver til 5 ,tekster")

De 5 almene teksttyper var:

- Brev

- Avisartikel

- Madopskrift

- Skoleskema

- Prisskilt fra supermarked

(Cronbachs alfa 0,95)

Oversigt over delopgaver i „Viden om sundhedsfaglige teksttyper“ ( 25 opgaver til 5 ,tekster")

De 5 sundhedsfaglige teksttyper var:

- Indholdsfortegnelse

- Side fra fagbog

- Vejledning i at give fodbad

- Besøgsskema for SOSU-hjælper

- Medicinetiket

(Cronbachs alfa 0,92)

\subsection{Læsestrategier}

\subsection{1 „Hvordan læser du fagtekster?“}

Til denne undersøgelse blev udformet en opgave, der skulle afdække elevernes læsestrategier. Opgaven bestod af en række udsagn, og eleverne skulle vælge, hvad der var hensigtsmæssigt at gøre. Hver opgave bestod af 4 udsagn, og kun et af udsagnene beskrev en hensigtsmæssig strategi. Der var 10 opgaver om „før-læsestrategier“, 10 opgaver om „mens du læserstrategier" og 5 opgaver med „efter-læsestrategier“ (Cronbachs alfa 0,73).

Eksempelvis lød en af opgaverne: 
Før jeg læser, er det en god idé at

$\square$ bede nogen læse teksten højt for mig

冈 læse overskriften for at se, hvad kapitlet handler om

$\square$ undersøge, om de fleste fagord har korte eller lange vokaler

$\checkmark$ undersøge, om illustrationerne er i rigtig rækkefølge, og om de giver mening

Opgaven er en bearbejdet dansk udgave af Schmidts „Metacomprehension index“, der omhandler læsning af skønlitterære tekster (Schmidt, 1990). Der var ingen tidsgrænse på denne opgave, men i praksis blev det forventet, at opgaven var besvaret inden for 30 minutter.

\subsection{Spørgeskemaer i undersøgelsen}

Der blev udformet en række spørgeskemaer til undersøgelsen.

\section{Spørgeskema om læsevaner og baggrundsoplysninger}

Ved uddannelsens start besvarede kursisterne et spørgeskema, der indeholdt spørgsmål om modersmål, eventuel specialundervisning, læsevaner og selvvurdering af læse- og stavefærdighed.

\section{Spørgeskema til alle kursister om deres uddannelsesforløb}

Ved uddannelsens afslutning besvarede kursisterne et spørgeskema om uddannelsesforløbet herunder, hvordan deres egen indsats havde været.

\section{Spørgeskema til LESS-SMART-gruppen om forløbet}

Kursister, der deltog i LÆS-SMART forløbet, blev spurgt om deres udbytte af dette særligt tilrettelagte forløb.

\subsubsection{Fordeling af prøver på de enkelte prøvegange}

Nedenfor ses en oversigt over, hvilke prøver og spørgeskemaer kursisterne blev præsenteret for ved de forskellige prøvegange. De enkelte prøver er beskrevet på de foregående sider. 


\section{Første og fjerde prøvegang: Ved uddannelsens start og afslutning}

- Spørgsmål om læsestrategier og metakognition „Hvordan læser du fagtekster?"

- Afkodningstest: „Find det ord, der er rigtigt stavet“

- Læseforståelse: „Læsetekster for unge og voksne“

\section{Anden og tredje prøvegang: Før og efter træningsforløbet}

- Sundhedsfagligt ordkendskab

- Alment ordkendskab

- Faglig læseforståelse, historie og biologi

- Kendskab til sundhedsfaglige teksttyper og almene teksttyper

\section{Spørgeskemaer i undersøgelsen}

- Spørgeskema med baggrundsoplysninger (ved uddannelsens start)

- Spørgeskema til LÆS SMART kursister om forløbet (efter træningsforløbet)

- Spørgeskema til alle kursister om udbytte og egen indsats i uddannelsesforløbet (ved uddannelsens afslutning)

Projektkursisterne er ligesom kursisterne i forstudiet på SOSU-Greve i 2009 blevet spurgt om, hvilket fag, de synes, der er det sværeste på SOSU, og her svarer næsten halvdelen „Naturfag“. Kursisterne skriver, at det er svært at forstå teksterne og at lære alle de nye ord. Det samme billede tegnede sig i vores forstudie og undervisningsobservationer på SOSUGreve i forbindelse med udvælgelse af fag til den fagintegrerede læseundervisning. Besvarelserne bekræftede en generel usikkerhed i forhold til Naturfag og en tilsvarende interesse for Sundhedsfag. Det tyder på, at valget af fag til den fagintegrerede læseundervisning blev foretaget på et rigtigt grundlag, selvom vi som udgangspunkt ikke kunne tage højde for projektkursisternes besvarelser, men af hensyn til planlægning af projektforløbet allerede havde udvalgt faget, inden projektkursisterne startede på deres uddannelse. 



\section{Resultater}

\subsection{SOSU-kursisternes baggrundsoplysninger og læsevaner}

SOSU-uddannelsen er karakteriseret ved, at der blandt kursisterne er en særdeles skæv kønsfordeling. Således var der blandt de kursister, der deltog i samtlige testgange, 2 mænd og 41 kvinder. Andelen af personer med andet modersmål end dansk er væsentligt højere end i den voksne befolkning som helhed. Således har $28 \%$ af de 43 kursister et andet modersmål end dansk. Andelen af kursister, der svarer ja til, at de er ordblinde er $7 \%$, og dette tal afviger ikke væsentligt fra, hvad der er fundet i den voksne befolkning i andre undersøgelser. Der er dog $14 \%$, der anfører, at de har modtaget specialundervisning, og $16 \%$ har en it-rygsæk. Itrygsække gives til ordblinde eller andre med massive ordlæsevanskeligheder, så derfor tyder det på, at der måske er flere end 7 \%, der har ordblindelignende vanskeligheder.

I spørgeskemaet blev der også spurgt til kursisternes læsevaner, både om de kunne lide at læse, om de syntes, det var svært at læse, og om hvor tit de læste dels i fritiden for sjov og dels i forbindelse med uddannelsen.

$91 \%$ af kursisterne svarer ja til, at de kan lide at læse, og $33 \%$ af kursisterne læser dagligt. $40 \%$ læser flere gange om ugen, mens $14 \%$ siger, at de læser sjældnere end en gang om ugen (2 elever siger, at de aldrig læser).

Når man er under uddannelse, vil der jo ofte være tekster, man skal læse hjemme som forberedelse til undervisningen, og her svarer 18,6\%, at de læser dagligt, mens der igen er $14 \%$, der svarer, at de læser sjældnere end en gang om ugen.

SOSU-kursisterne vurderer egne læsefærdigheder forholdsvis højt. Det er kun 2 kursister, der angiver, at de ikke er så gode til at forstå tekster, og $65 \%$ af kursisterne svarer, at de forstår tekster godt eller temmelig godt. Ingen kursister svarer, at de ikke er så gode til at læse ord. Her svarer alle enten middel, temmelig godt eller virkelig godt. Der er dog 18,6 \% af kur- 
sisterne, der svarer, at de læser langsomt, og kun én kursist svarer, at han/hun læser virkelig hurtigt, så mange af kursisterne har en oplevelse af utilstrækkelig læsefærdighed.

Tabel 1. Gennemsnit og spredninger for de forskellige kursistgrupper i under søgelsen

\begin{tabular}{|c|c|c|}
\hline Test & $\begin{array}{l}\text { Før træningsforløbet } \\
17 \text { kontrol } \\
26 \text { LÆES SMART }\end{array}$ & $\begin{array}{l}\text { Efter træningsforløbet } \\
17 \text { kontrol } \\
26 \text { LAES SMART }\end{array}$ \\
\hline $\begin{array}{l}\text { Læsetekster for unge og voksne (max } 60) \\
\text { Alle } \\
\text { LESS SMART } \\
\text { Kontrol }\end{array}$ & $\begin{array}{l}40,21(11,49) \\
40,50(11,42) \\
39,76(11,93)\end{array}$ & $\begin{array}{l}42,77(10,48) \\
42,42(10,82) \\
43,29(10,25)\end{array}$ \\
\hline $\begin{array}{l}\text { Faglig læsning - historie (max 19) } \\
\text { Alle } \\
\text { LEES SMART } \\
\text { Kontrol }\end{array}$ & $\begin{array}{l}11,86(4,21) \\
11,73(4,36) \\
12,06(4,10)\end{array}$ & $\begin{array}{l}12,74(4,14) \\
12,85(4,43) \\
12,59(3,76)\end{array}$ \\
\hline $\begin{array}{l}\text { Faglig læsning - biologi (max 19) } \\
\text { Alle } \\
\text { LAES SMART } \\
\text { Kontrol }\end{array}$ & $\begin{array}{l}11,49(4,26) \\
11,15(4,29) \\
12,00(4,30)\end{array}$ & $\begin{array}{l}13,42(3,67) \\
12,81(4,10) \\
14,35(2,76)\end{array}$ \\
\hline $\begin{array}{l}\text { Find det ord der er rigtigt stavet ( } \max 113 \text { ) } \\
\text { Alle } \\
\text { LAES SMART } \\
\text { Kontrol }\end{array}$ & $\begin{array}{l}43,30(18,54) \\
44,08(19,30) \\
42,12(17,83)\end{array}$ & $\begin{array}{l}47,05(20,18) \\
46,27(20,49) \\
48,24(20,28)\end{array}$ \\
\hline $\begin{array}{l}\text { Alment ordkendskab - Semantisk (max 25) } \\
\text { Alle } \\
\text { LAES SMART } \\
\text { Kontrol }\end{array}$ & $\begin{array}{l}18,88(3,99) \\
18,69(3,82) \\
19,18(4,33)\end{array}$ & $\begin{array}{l}19,35(3,82) \\
18,77(3,58) \\
20,24(4,10)\end{array}$ \\
\hline $\begin{array}{l}\text { Fagligt ordkendskab - Sundhedsfag (max } 30) \\
\text { Alle } \\
\text { LASS SMART } \\
\text { Kontrol }\end{array}$ & $\begin{array}{l}22,93(6,07) \\
22,23(6,54) \\
24,00(5,29)\end{array}$ & $\begin{array}{l}25,16(4,06) \\
24,46(4,52) \\
26,24(3,07)\end{array}$ \\
\hline $\begin{array}{l}\text { Viden om teksttyper almen (max 25) } \\
\text { Alle } \\
\text { LAES SMART } \\
\text { Kontrol }\end{array}$ & $\begin{array}{l}16,37(4,52) \\
16,73(4,50) \\
15,82(4,63)\end{array}$ & $\begin{array}{l}16,86(5,21) \\
17,15(5,63) \\
16,41(4,61)\end{array}$ \\
\hline $\begin{array}{l}\text { Viden om teksttyper Sundhedsfag (max 25) } \\
\text { Alle } \\
\text { LAES SMART } \\
\text { Kontrol }\end{array}$ & $\begin{array}{l}12,19(4,87) \\
11,77(4,96) \\
12,82(4,80)\end{array}$ & $\begin{array}{l}14,86(6,19) \\
14,92(6,10) \\
14,76(6,52)\end{array}$ \\
\hline $\begin{array}{l}\text { Hvordan læser du fagtekster ( } \max 25 \text { ) } \\
\text { Alle } \\
\text { LAES SMART } \\
\text { Kontrol }\end{array}$ & $\begin{array}{l}9,07(4,77) \\
8,69(5,09) \\
9,65(4,31)\end{array}$ & $\begin{array}{l}10,47(4,69) \\
11,04(4,80) \\
9,59(4,50)\end{array}$ \\
\hline
\end{tabular}




\subsection{Hvordan er SOSU-kursisternes skriftsproglige færdigheder?}

I tabel 1 ses gennemsnit og spredning for testresultaterne før og efter den særligt tilrettelagte træningsundervisning. Gennemsnit og spredning er opgjort dels for alle kursister og dels for de to kursistgrupper separat (LÆS SMART og kontrolgruppen). Hvis man ser på gennemsnittene i tabellen, er der en tendens til, at LÆS SMART-gruppen har lidt lavere gennemsnit end kontrolgruppen på en lang række af prøverne, men denne forskel er ikke signifikant. I det følgende beskrives SOSU-kursisternes færdigheder ved uddannelsens start, og her vil kontrolgruppen og LÆS SMART-gruppen blive behandlet som en gruppe. I alt 139 kursister deltog i undersøgelsen, men det er desværre kun 43 af disse, der har deltaget i samtlige testgange. Det er kun disse 43 kursister, der indgår i analyserne for ellers ville resultaterne ikke være direkte sammenlignelige, da det ville være forskellige kursister, der indgik i de enkelte analyser. Selvom det i skemaet kan se ud til, at kontrolgruppen scorer lidt højere end LÆS SMART-gruppen på mange af prøverne ved prætesten, så er ingen af disse forskelle signifikante, hvilket betyder, at de to grupper starter ud med ens færdigheder på de afdækkede områder. Hvis vi sammenligner den gruppe kursister, der har afbrudt uddannelsen, med de øvrige kursister (disse fremgår ikke af skemaet), så er der ikke signifikante forskelle i deres prøveresultater, og det samme er tilfældet for den gruppe af kursister, der har forlænget deres uddannelse.

\subsubsection{Funktionel læsefærdighed almen og faglig}

I den almene læseforståelsesprøve løste kursisterne i gennemsnit 40,21 opgaver rigtigt (maximumscoren på denne opgave er 60). Dette svarer til det resultat, som voksne i Almen Voksenuddannelse (AVU) opnåede i Arnbaks undersøgelse (Arnbak \& Elbro, 1999). Dog er der en lidt større spredning på SOSU-kursisternes resultat, hvilket fortæller, at kursistgruppen kommer med meget forskellige læsemæssige forudsætninger. I vejledningen til Læsetekster for unge og voksne (Arnbak, 2001) kategoriseres man som en voksen med utilstrækkelige funktionelle læsefærdigheder, hvis scoren ligger mellem 36 og 44, og som en voksen med ringe 
funktionelle læsefærdigheder, hvis scoren ligger under 36 rigtige. Ved uddannelsesstart havde 30,2 \% af kursisterne ringe funktionelle læsefærdigheder efter denne kategorisering, og yderligere 23,3\% havde utilstrækkelige funktionelle læsefærdigheder. Så over halvdelen af kursisterne havde ved uddannelsens start utilstrækkelige funktionelle læsefærdigheder i forhold til tekster, som voksne støder på i deres hverdag. Hvis dette sammenholdes med, at kun 2 af kursisterne svarede, at de havde svært ved at læse og forstå tekster, så er der altså en tendens til, at SOSUkursisterne ikke i så stor udstrækning oplever at have vanskeligheder. En stor del af dem, der har objektive vanskeligheder (scorer lavt på læseforståelsesopgaven), har ikke subjektive vanskeligheder (de synes egentlig selv, at de læser ok). Disse kursister kan derfor mangle motivation for at deltage i ekstra læsetræning eller for at arbejde intensivt med læsning, fordi de ikke selv har oplevelse af at have vanskeligheder. Dette svarer til, hvad man har fundet i andre undersøgelser, hvor voksne har vurderet egen læsning (Elbro et al, 1991; Arnbak \& Borstrøm, 2004).

Men hvordan er kursisternes færdigheder, når de skal læse fagtekster? Her klarer kursisterne sig ved uddannelsens start omkring samme niveau som elever i 7.-9. klasse. Deres gennemsnit afviger ikke signifikant fra eleverne i 7. klasse eller eleverne i 9. klasse på hverken historie- og biologiteksten. Kursisternes resultat er således lidt, men ikke signifikant højere end elever i 7. klasses score og lidt, men ikke signifikant lavere end elever i 9. klasses score. Kursister, der besvarer halvdelen eller under halvdelen af spørgsmålene til en fagtekst korrekt, må siges at have haft visse problemer med at forstå denne tekst. I historielæseprøven har $30 \%$ af kursisterne 9 eller færre rigtige, og i biologilæseprøven har $35 \%$ af kursisterne 9 eller færre rigtige. Dette resultat svarer til resultatet for elever i 7. og 8. klasses resultat og viser, at en stor del af SOSU-kursisterne har vanskeligt ved at forstå fagtekster, der normalt anvendes i 7. og 8. klasse. 


\subsubsection{Afkodning}

Kursisternes afkodningsfærdigheder blev afdækket med „Find det ord der er rigtigt stavet". Ved uddannelsens start havde SOSU-kursisterne i gennemsnit 43,3 korrekte på denne opgave. Dette svarer til elever i 7.-9. klasse. SOSU-kursisternes gennemsnit afviger ikke signifikant fra hverken eleverne i 7. klasse eller eleverne i 9. klasse på afkodningsfærdighed og er således lidt, men ikke signifikant højere end elever i 7. og 8. klasses score og lidt, men ikke signifikant lavere end elever i 9. klasses score.

\subsubsection{Ordkendskab}

Kursisternes ordkendskab blev afdækket med to forskellige ordkendskabsprøver, en almen ordkendskabstest og en sundhedsfaglig ordkendskabstest. Den almene har tidligere været anvendt til elever i folkeskolens ældste klasser, og SOSU-kursisternes gennemsnitlige score på 18,88 er signifikant bedre end elever i 7. og 8. klasse og på samme niveau som elever i 9. klasse. Ordkendskabsprøven i sundhedsfag var udviklet til denne undersøgelse, og kursisterne havde gennemsnitlig 22,93 korrekte (maximumscore 30), men med en forholdsvis stor spredning i kursisternes færdigheder, hvilket indikerer, at der er meget store forskelle på, hvor godt kursisterne er klædt sprogligt på til deres nye fagområde.

\subsubsection{Kendskab til teksttyper}

Der er til undersøgelsen udviklet to parallelle prøver til afdækning af kursisternes kendskab til forskellige teksttyper, en med almene tekster og en med sundhedsfagstekster. På begge opgaver kan man maksimalt score 25 korrekte. På de almene tekster løste SOSU-kursisterne i gennemsnit 16,37 opgaver korrekt, og i de sundhedsfaglige tekster løste de i gennemsnit 11.36 opgaver korrekt ved uddannelsens start. Hvis man løste under halvdelen af opgaverne korrekt, tyder det på en usikkerhed i at navigere i forskellige teksttyper. Ved uddannelsens start havde $20 \%$ af kursisterne under halvdelen af opgaverne korrekt i de almene tekster, mens $53 \%$ af kursisterne scorede på dette niveau i sundhedsteksterne. En større del af kursisterne var altså ved uddannelsens start usikre på, hvordan de skulle navigere i de sundhedsfaglige tekster, hvilket ikke er overraskende, da det 
jo ikke er tekster, de tidligere har mødt på samme måde som de almene tekster. Det betyder, at mange SOSU-kursister har brug for en indføring i sundhedsfagets teksttyper, men når der ikke følger en undervisningsvejledning med til SOSU-bøgerne (og andre lærebøger til voksne), så der er umuligt at forudsige, hvor systematisk denne indføring vil være.

\subsubsection{Læsestrategier}

Opgaven „Hvordan læser du fagtekster?“ er en dansk bearbejdning af en amerikansk opgave. Der var 25 spørgsmål, hvor kursisterne skulle vælge, hvad der var den mest hensigtsmæssige strategi i forhold til fagteksten. Alle kursister scorede lavt på denne opgave. De havde gennemsnitlig 8,92 korrekte, og $80 \%$ af kursisterne svarede rigtigt på under halvdelen af spørgsmålene. Man kan ikke umiddelbart fra dette resultat slutte, at kursisterne ikke har hensigtsmæssige læsestrategier ved læsning af fagtekster, men kursisternes resultat på denne opgave tyder på, at størsteparten af dem er usikre på, hvilke strategier der er de mest hensigtsmæssige, når de blandt fire svarmuligheder skal vælge den mest hensigtsmæssige. Da opgaven ikke har været anvendt tidligere i denne version, har vi ingen resultater at sammenligne med, og en mulighed er derfor også, at opgaven er blevet for svær. De svarmuligheder, kursisterne skal vælge imellem, er forholdsvis lange, så det kan være, at kursisterne er kørt sur i al denne læsning og derfor ikke har fået reflekteret i tilstrækkelig grad, før de valgte en af svarmulighederne.

\section{Sammenhænge mellem de forskellige prøver}

For at undersøge, hvor stærke sammenhænge der er mellem de enkelte delprøver, laves parvise korrelationsberegninger. Her afdækkes, hvor stærk sammenhæng der er mellem kursisternes resultat på to givne prøver. Korrelationskoefficientens størrelse fortæller, om der er sammenhæng mellem elevens score på to prøver. Signifikante korrelationer er i skemaet nedenfor markeret med en eller flere stjerner. Herefter kan man af koefficientens størrelse se, hvor stærk sammenhængen er. Hvis koefficienten er 1, er der en perfekt lineær sammenhæng mellem de to variable, så jo tættere koefficienten er på 1, desto stærkere er sammenhængen. 
Tabel 2. Pearsons korrelationskoefficienter mellem de forskellige prøver i undersøgelsen. Korrelationerne i skemaet er lavet ud fra de 43 kursister med komplette datasæt. * $\mathrm{p}<0,05, * * \mathrm{p}<0,01, * * * \mathrm{p}<0,001$

\begin{tabular}{|c|c|c|c|c|c|c|c|c|c|}
\hline & $\begin{array}{l}\text { Læse-tekster } \\
\text { for unge og } \\
\text { voksne }\end{array}$ & $\begin{array}{l}\text { Faglig } \\
\text { Læse- } \\
\text { forståelse } \\
\text { historie }\end{array}$ & $\begin{array}{l}\text { Faglig } \\
\text { Læse- } \\
\text { forståelse } \\
\text { Biologi }\end{array}$ & $\begin{array}{l}\text { Find det ord } \\
\text { der er rigtigt } \\
\text { stavet }\end{array}$ & $\begin{array}{l}\text { Alment } \\
\text { Ordkend- } \\
\text { skab }\end{array}$ & $\begin{array}{l}\text { Sundheds- } \\
\text { fagligt ord- } \\
\text { kendskab }\end{array}$ & $\begin{array}{l}\text { Viden om } \\
\text { almene } \\
\text { teksttyper }\end{array}$ & $\begin{array}{l}\text { Viden om } \\
\text { sundheds- } \\
\text { faglige } \\
\text { teksttyper }\end{array}$ & $\begin{array}{l}\text { „Hvordan } \\
\text { læser du } \\
\text { fagtekster?“ }\end{array}$ \\
\hline $\begin{array}{l}\text { Læsetekster for unge og } \\
\text { voksne }\end{array}$ & & $0,70 * * *$ & $0,62 * * *$ & $0,72 * * *$ & $0,70 * * *$ & $0,62 * * *$ & $0,70 * * *$ & $0,76^{* * *}$ & $\begin{array}{l}0,08 \\
\text { ikke sign }\end{array}$ \\
\hline Faglig læsning - Historie & & & $0,65 * * *$ & $0,38 *$ & $0,59 * * *$ & $0,42 *$ & $0,62^{* * *}$ & $0,70 * * *$ & $\begin{array}{l}0,28 \\
\text { ikke sign }\end{array}$ \\
\hline Faglig læsning - Biologi & & & & $0,56 * * *$ & $0,50 * * *$ & $0,59 * * *$ & $0,48 * * *$ & $0,56 * * *$ & $\begin{array}{l}0,24 \\
\text { ikke sign }\end{array}$ \\
\hline $\begin{array}{l}\text { Find det ord der er rigtigt } \\
\text { stavet }\end{array}$ & & & & & $0,54 * * *$ & $0,50 * * *$ & $0,50 * * *$ & $0,59 * * *$ & $\begin{array}{l}0,121 \\
\text { ikke sign }\end{array}$ \\
\hline Alment ordkendskab & & & & & & $0,53 * * *$ & $0,56 * * *$ & $0,65^{* * *}$ & $\begin{array}{l}0,23 \\
\text { ikke sign }\end{array}$ \\
\hline $\begin{array}{l}\text { Sundhedsfagligt ord- } \\
\text { kendskab }\end{array}$ & & & & & & & $0,34^{*}$ & $0,43^{* *}$ & $\begin{array}{l}-0,06 \\
\text { ikke sign }\end{array}$ \\
\hline $\begin{array}{l}\text { Viden om almene tekst- } \\
\text { typer }\end{array}$ & & & & & & & & $0,8^{* * * 0}$ & $0,41^{* *}$ \\
\hline $\begin{array}{l}\text { Viden om sundheds- } \\
\text { faglige teksttyper }\end{array}$ & & & & & & & & & $\begin{array}{l}0,28 \\
\text { ikke sign }\end{array}$ \\
\hline
\end{tabular}


Som det fremgår af tabel 2, er der stærke signifikante sammenhænge mellem de fleste prøver. Den eneste prøve, hvor kursisternes resultat ikke hænger sammen med deres resultat på de øvrige prøver, er opgaven „Hvordan læser du fagtekster?“. Denne prøve korrelerer kun signifikant med teksttypeopgaven med de almene tekster. Dette kan virke overraskende, men som tidligere beskrevet havde kursisterne store vanskeligheder med „Hvordan læser du fagtekster?“, og især ved prætesten var det en prøve, hvor mange scorede på chanceniveau, måske fordi de ikke forstod svarmulighederne, eller løb sur i de teksttunge svarmuligheder, som de skulle vælge imellem.

Umiddelbart ville man måske have forventet stærkere indbyrdes sammenhænge mellem prøver, der var af samme type - altså stærkere sammenhænge mellem læseforståelsesprøverne indbyrdes og mellem ordkendskabsprøverne indbyrdes. Dette er kun tilfældet for de to teksttypeopgaver, som har en indbyrdes korrelation på 0,8 . De to forskellige ordkendskabsprøver korrelerer lige så højt med andre prøver, som de gør med hinanden, og måske er det heller ikke så underligt. De afdækker jo netop forskellige aspekter af ordkendskabet, og man bør forvente, at der vil være stor forskel på, hvordan voksne er rustet på henholdsvis alment og sundhedsfagligt ordkendskab afhængig af undervisning og ikke mindst egne interesser og erfaringer.

Det samme billede tegner sig til dels for de tre læseforståelsesprøver. Her er sammenhængen heller ikke så høj, som man måske kunne forvente. Imidlertid er det også forskellige typer spørgsmål til teksterne i den almene og de faglige læseforståelsesprøver. Spørgsmålene til biologiteksten omhandler i stor udstrækning definitioner samt forståelse af figurer. Spørgsmålene til historieteksten handler især om forståelse af årsagssammenhænge og hvilke faktorer, der har haft betydning for udviklingen. For at kunne besvare spørgsmålene til de almene voksentekster skal man kunne holde rede på et handlingsforløb og finde det overordnede tema $\mathrm{i}$ en tekst samt lokalisere bestemte informationer i tabeltekster. Som det fremgår, er spørgsmålene på den måde delvis afhængige af teksttypen, og derfor vil der være forskel på, hvor let eller svært man har ved at løse opgaver til de forskellige teksttyper. 
I tabel 2 kan man se, at der generelt er meget stærke sammenhænge mellem de forskellige prøver. Både ordkendskab, afkodning og kendskab til teksttyper korrelerer højt med de forskellige læseforståelsesprøver, hvilket vidner om, at kursisternes resultater på disse prøver kan forklare en stor del af variationen i deres læseforståelse.

I tabel 2 er det imidlertid svært at få det fulde overblik over resultaterne. Eksempelvis kan man ikke se, hvor stor en selvstændig del af variationen, de enkelte delprøver forklarer. Er det den samme del af variationen i læseforståelse, som afkodning, ordkendskab og teksttypekendskab forklarer? Hvor stor en del af variationen i læseforståelse kan disse prøver tilsammen forklare? Det kan korrelationerne alene ikke give svaret på. Svar på sådanne spørgsmål får man ved at lave trinvise lineære regressionsanalyser, hvor man ser på, hvor stor en selvstændig del af variationen i læseforståelse, der eksempelvis kan forklares af scoren på den almene ordkendskabsprøve, når der forinden er taget højde for kursisternes afkodningsfærdighed. På den måde får man mulighed for at se nærmere på, hvor stor en selvstændig del af variationen de enkelte delprøver forklarer.

\subsection{Hvad kan forklare variation i læseforståelse?}

Såvel afkodning, ordkendskab og teksttypekendskab forklarede en del af variationen i læseforståelse, men spørgsmålet er, om det er den samme del af variationen i læseforståelse, disse færdigheder forklarer.

I tabel 3 nedenfor ses, hvor stor selvstændig del af variationen henholdsvis afkodning, ordkendskab og teksttypekendskab forklarer ved uddannelsens start. 


\begin{tabular}{|c|c|c|c|}
\hline & $\begin{array}{l}\text { \%- af variationen i } \\
\text { almen læseforståel- } \\
\text { se, der kan forklares } \\
\text { ved delprøven }\end{array}$ & & $\begin{array}{l}\text { \%- af variationen i } \\
\text { almen læseforstå- } \\
\text { else, der kan } \\
\text { forklares ved } \\
\text { delprøven }\end{array}$ \\
\hline Trin 1 & & Trin 1 & \\
\hline Afkodning & $51 \%$ & Ordkendskab, almen & $48 \%$ \\
\hline Trin 2 & & Trin 2 & \\
\hline Ordkendskab, almen & $14 \%$ & Afkodning & $17 \%$ \\
\hline Trin 3 & & Trin 3 & \\
\hline Teksttypekendskab, almen & $6 \%$ & Teksttypekendskab, almen & $6 \%$ \\
\hline$\%$ i alt & $71 \%$ & & $71 \%$ \\
\hline
\end{tabular}

Til venstre i tabellen er der først kontrolleret for afkodning, og herefter er scoren på alment ordkendskab lagt ind i regressionsligningen. Til højre i tabellen er scoren på alment ordkendskab lagt først ind i regressionsligningen, og herefter er scoren på afkodning lagt ind. Som det fremgår af tallene, forklarer ordkendskab og afkodning en lige stor del af kursisternes almene læseforståelse. Teksttypekendskab forklarer også en stor del af variationen. Når der først kontrolleres for elevernes afkodningsfærdighed og ordkendskab, bliver der ikke så meget tilbage at forklare, men selv efter der er kontrolleret for disse færdigheder, kan teksttypekendskab forklare yderligere $6 \%$ af variationen. Teksttypekendskab alene forklarer $48 \%$ af variationen, hvis dette resultat lægges ind på trin 1 . Disse tre prøver kan tilsammen forklare $71 \%$ af variationen i kursisternes almene læseforståelse, og dette er en større andel af variationen end i undersøgelsen med læseforståelse i folkeskolens ældste klasser, hvor 3 lignende prøver forklarede omkring halvdelen af variationen i læseforståelse (Petersen, 2008). Hvis afkodning lægges ind, efter der er kontrolleret for ordkendskab og teksttypekendskab, kan det stadig forklare yderligere 10 $\%$ af variationen i almen læseforståelse. 


\begin{tabular}{|c|c|c|c|}
\hline & $\begin{array}{l}\text { \%- af variationen i faglig } \\
\text { læseforståelse, biologi, } \\
\text { der kan forklares ved } \\
\text { delprøven }\end{array}$ & & $\begin{array}{l}\text { \%- af variationen i faglig } \\
\text { læseforståelse, biologi, } \\
\text { der kan forklares ved } \\
\text { delprøven }\end{array}$ \\
\hline Trin 1 & & Trin 1 & \\
\hline $\begin{array}{l}\text { Sundhedsfagligt } \\
\text { ordkendskab }\end{array}$ & $34 \%$ & $\begin{array}{l}\text { Teksttypekendskab, } \\
\text { sundhedsfag }\end{array}$ & $30 \%$ \\
\hline Trin 2 & & Trin 2 & \\
\hline $\begin{array}{l}\text { Teksttypekendskab, } \\
\text { sundhedsfag }\end{array}$ & $10 \%$ & $\begin{array}{l}\text { Sundhedsfagligt } \\
\text { ordkendskab }\end{array}$ & $14 \%$ \\
\hline$\%$ i alt & $44 \%$ & & $44 \%$ \\
\hline
\end{tabular}

I tabel 4 ses, hvilke komponenter der kunne forklare kursisternes faglige læseforståelse på biologiteksten. Der er indledningsvis lavet regressionsanalyser med den almene og den sundhedsfaglige ordkendskabsprøve. Den sundhedsfaglige ordkendskabstest havde størst selvstændig forklaringsværdi, og hvis der var kontrolleret for denne, kunne den almene ordkendskabsprøve ikke bidrage med yderligere forklaring. I disse analyser er der derfor anvendt den sundhedsfaglige ordkendskabsprøve. Ingen af ordene fra den faglige ordkendskabsprøve indgår i teksten, men de er fra samme fagområde. På samme vis er anvendt teksttypekendskabsopgaven med sundhedsfagstekster, fordi biologiteksten har flere lighedspunkter med en sundhedsfagstekst end med en almen tekst. Når der var kontrolleret for både sundhedsfagligt ordkendskab og kendskab til sundhedsfaglige teksttyper, så kunne afkodningsfærdighed ikke bidrage yderligere til at forklare variationen i faglig læseforståelse. Afkodningen spiller også her en stor rolle - den kan alene forklare omkring $30 \%$ af variationen i faglig læseforståelse, men hvis man kontrollerer for sundhedsfagligt ordkendskab og kendskab til sundhedsfaglige tekster, kan afkodningen ikke bidrage med yderligere forklaring. Det ser altså ud som om, der er forskel på, hvilke færdigheder der er centrale ved læsning af fagtekster og læsning af almene tekster. De almene tekster er tekster, som alle voksne borgere støder på, og derfor kan man i højere grad navigere i dem. Hvor godt og hurtigt, man gør det, er i høj grad afhængig af afkodningshastigheden. I biologiteksten er der dels tekst, der skal læses, og dels en række faktabok- 
se og figurer til illustration af pointerne i teksten. Derfor bliver kendskab til, hvordan naturfaglige tekster er opbygget, mere afgørende.

Der er også lavet lineære regressionsanalyser ud fra prøveresultaterne ved uddannelsens afslutning, og her var det for biologitekstens vedkommende en mindre del af variationen (33\%), der kunne forklares ud fra sundhedsfagligt ordkendskab og kendskab til sundhedsfaglige teksttyper, primært fordi ordkendskabsprøven ikke forklarede så meget variation ved uddannelsens afslutning ( $24 \% \bmod 34 \%$ ved uddannelsens start). Der var tendens til loftseffekt på prøven, så derfor var den ved uddannelsens afslutning ikke så følsomt et redskab i forhold til variationen blandt de bedste kursister. For den almene læseforståelsesprøve var billedet det samme som ved uddannelsens start. De 3 prøver kunne tilsammen forklare $75 \%$ af variationen i læseforståelse, og det ser ud til, at teksttypekendskabet kan forklare mere ved uddannelsens afslutning. Efter at der er kontrolleret for ordkendskab og afkodning, forklarer teksttypekendskab yderligere $13 \%$ ved uddannelsens afslutning. Især blandt svage afkodere kan en højere bevidsthed om teksters opbygning lette navigationsarbejdet, og undersøgelser blandt voksne svage afkodere har også vist, at deres teksttypekendskab har stor betydning for, hvor godt de læser og forstår tekster (Knudsen, 2003).

Der blev anvendt de samme prøver igen ved afslutningen på uddannelsen. Korrelationerne mellem de forskellige prøver ved uddannelsens afslutning svarede til korrelationerne fra uddannelsens start, og disse er derfor ikke gengivet. Eneste forskel blev fundet på prøven „Hvordan læser du fagtekster?“. Ved uddannelsens afslutning korrelerede denne prøve signifikant med kursisternes resultat på de 3 læseforståelsesprøver, hvilket ikke var tilfældet ved uddannelsens start. Det kan skyldes, at nogle kursister har lært strategier, som de kan bruge i læsningen af tekster, men det kan også være et resultat af, at kursisterne ved at læse tekster i forbindelse med en uddannelse er blevet mere bevidste om, hvad de gør og derfor bedre kan besvare „Hvordan læser du fagtekster?“. 


\subsection{Hvad sker der med SOSU-kursisternes færdigheder i løbet af uddannelsen?}

Kursisterne udfyldte også et spørgeskema ved afslutningen på uddannelsesforløbet. Her svarede $70 \%$, at de havde lært rigtig meget, og de sidste 30 \% svarede, at de havde lært en del. Kursisterne blev også spurgt, hvor svær, de syntes, uddannelsen havde været, og her svarede $49 \%$, at det havde været svært. En stor del af kursisterne følte, at de skulle stå på tæer for at hænge på.

Kursisterne er blevet testet med de samme prøver i starten af uddannelsesforløbet og igen ved uddannelsesforløbets afslutning. Dette giver mulighed for at se nærmere på, om kursisternes færdigheder udvikler sig i løbet af uddannelsesforløbet. For at kunne sige noget om dette, blev der lavet en række en-vejs ANOVA-er med repeated measures.

Kursisterne havde signifikant fremgang på faglig læseforståelse, biologi $(F=12,63, p<0,01)$, sundhedsfagligt ordkendskab $(F=9,40, p<0,01)$, sundhedsfaglige teksttyper $(\mathrm{F}=19,07, \mathrm{p}<0,01)$, „Find det ord der er rigtigt stavet" $(\mathrm{F}=6,71, \mathrm{p}<0,01)$ og Læsetekster for unge og voksne $(\mathrm{F}=13,80, \mathrm{p}<0,01)$.

Der var ikke signifikant fremgang på faglig læseforståelse, historie $(F=3,11, p>0,05)$, alment ordkendskab $(F=3,11, p>0,05)$ og almene teksttyper $(F=1,11, p>0,05)$ og „Hvordan læser du fagtekster?“ ( $F=3,49, p>0,05)$.

Der er altså særligt fremgang på de prøver, der ligger tæt på det, kursisterne har arbejdet med i deres uddannelsesforløb (sundhedsfaglige teksttyper, sundhedsfagligt ordkendskab og biologteksten), men samtidig ses en effekt på kursisternes læsning af almene voksentekster og deres afkodning. Dette stemmer fint overens med, at man i andre undersøgelser har set sammenhæng med ordlæsefærdigheder og læseerfaring. Meget tyder på, at kursisterne får læst mere i deres uddannelsesperiode, end de plejer, og derfor får de trænet og styrket deres almene „læsekondi“. Øvelse gør mester, og dette er sandsynligvis også forklaringen på effekten på de almene voksentekster. Kursisterne er jo stødt på almene voksentekster i de øvrige fag, og derfor har de også fået øvet sig i at læse denne type tekster. Når man er i et uddannelsesforløb, læser man tekster, hvor man ef- 
terfølgende skal gøre rede for indholdet og måske endda skrive resumé af det. Sådanne aktiviteter har i træningsundersøgelser i grundskolen vist sig at have positiv effekt på elevernes læseforståelse. At der ikke er signifikant fremgang på læsningen af historieteksten skyldes måske, at der ikke i uddannelsesforløbet er blevet arbejdet med denne type fagtekster.

Der var altså signifikant fremgang på kursisternes gennemsnitlige resultat på en lang række af prøverne. Det er et udtryk for, at niveauet generelt er blevet bedre, men spørgsmålet er, om andelen af kursister, der har vanskeligheder på de enkelte prøver, også er blevet mindre. Ved slutningen af uddannelsen havde 23,3\% af kursisterne ringe funktionelle læsefærdigheder, og 27,9 \% havde utilstrækkelige funktionelle læsefærdigheder. Så lidt over halvdelen af kursisterne har stadig utilstrækkelige funktionelle læsefærdigheder ved slutningen af uddannelsen. Det ser dog ud til, at gruppen med ringe funktionelle læsefærdigheder er blevet mindre. Nogle af de allersvageste funktionelle læsere har tilsyneladende klaret sig bedre på prøven ved slutningen af uddannelsesforløbet. Desværre er gruppestørrelserne for små til, at der kan laves statistiske analyser af delgrupper. Det samme billede tegner sig i fagtekstlæsningen, hvor der ved uddannelsens afslutning er en mindre andel af kursisterne, som har vanskeligheder med fagteksterne, end der var ved uddannelsens start. Ved efter-testen havde $20 \%$ af kursisterne 9 eller færre rigtige i historielæseprøven, og til sammenligning var denne andel $30 \%$ ved starten af uddannelsesforløbet. I biologilæseprøven har $14 \%$ af kursisterne 9 eller færre rigtige ved eftertesten, sammenlignet med $35 \%$ ved uddannelsens start. Dette resultat er mere markant end resultatet på historielæseprøven, og det skyldes sandsynligvis, at biologiteksten i højere grad ligner den type fagtekster, som kursisterne har læst på uddannelsen.

Ved uddannelsens afslutning havde $16 \%$ af kursisterne under halvdelen af opgaverne korrekt i teksttypeopgaven med de almene tekster, mens $35 \%$ af kursisterne scorede på dette niveau i sundhedsteksterne. En større del af kursisterne var altså stadig ved uddannelsens afslutning usikre på, hvordan de skulle navigere i de sundhedsfaglige tekster, men andelen af kursister, der scorer under halvdelen rigtige, er faldet betydeligt. Ved uddannelsens start var det $53 \%$ af kursisterne, der havde under halvde- 
len af opgaverne korrekt på sundhedsfagsteksterne. Med hensyn til de almene tekster har der ikke været den samme udvikling.

Opgaven „Hvordan læser du fagtekster?“ var svær for af mange af kursisterne, og ved uddannelsens afslutning var der stadig $63 \%$ af kursisterne, der svarede rigtigt på færre end halvdelen af spørgsmålene (mod 80 \% ved uddannelsens start).

\subsection{Sammenhænge mellem læsevaner og læsefærdighed}

Selvom det naturligvis er interessant at beskrive SOSU-kursisternes funktionelle læsefærdigheder, så er det måske endnu mere interessant at se, hvilke andre ting der adskiller gode og dårlige læsere. På den måde kan man pejle sig ind på mulige årsager til og konsekvenser af funktionelle læsevanskeligheder. Det kan igen give idéer til, hvordan man kan løfte læseniveauet i gruppen af svage læsere. Af denne grund ønskede vi at undersøge, om der var forskel på svage og gode læseres læsevaner i vores undersøgelse. Da der desværre endte med kun at være komplette datasæt fra 43 kursister i træningsundersøgelsen, vanskeliggør det analyser, hvor vi sammenligner gode og dårlige læseres besvarelse. Når grupperne bliver små, skal de statistiske analyser tolkes med forsigtighed. Vi har sammenlignet kursister med god og dårlig funktionel læsefærdigheds besvarelser af spørgeskemaet. Kursisterne blev inddelt i disse to grupper på baggrund af deres resultat på læsetekster for unge og voksne. De kursister, der scorede 44 rigtige eller derunder, blev kategoriseret som dårlige læsere, og dem, der scorede over 44 rigtige, blev kategoriseret som gode læsere. Vi kan i besvarelserne se nogle tendenser for disse to grupper. Alle uanset læseniveau svarer, at de er glade for at læse. Det ser dog ud til, at de dårligere læsere ikke læser i så stor udstrækning i deres fritid som de gode læsere - hverken for sjov derhjemme (gamma $=0,64, p<0,01$ ) eller i forbindelse med SOSU hjemme (gamma $=0,64 ; \mathrm{p}<0,01$ ).

På de fleste punkter er der ikke forskel på, hvordan gode og dårlige læsere vurderer deres læsning. Eneste forskel er, at de dårlige læsere i større ud- 
strækning svarer, at de læser langsomt (gamma= 0,68, $\mathrm{p}<0,01$ ). Måske er det sådan, at man i højere grad opdager, at man læser langsomt, end at man ikke forstår det, man læser. De dårlige læsere vurderer i højere grad teksterne på SOSU som svære/middel frem for lette, end de gode læsere gør.

De gode læsere svarer også i større udstrækning, at de har været aktive i alle timer (gamma=0,87, p>0,001). Således svarer 19 af 20 gode læsere, at de har været aktive i alle timer sammenlignet med 13 af 23 dårlige læsere. Til gengæld er det især de dårlige læsere, der synes, de har lært meget $\mathrm{i}$ løbet af uddannelsen (gamma =0,59, p <0,001). 19 af de 23 dårligere læser svarer, at de har lært meget i løbet af uddannelsen sammenlignet med 11 af de 20 gode læsere. Forklaringen på dette er måske, at de gode læsere fra start føler sig mere ovenpå stoffet, har lettere ved at forstå teksterne og ikke har oplevelsen af, at det er svært tilgængeligt stof. 


\section{Er der en særlig effekt af LAES SMART forløbet?}

Der var altså fremgang i kursisternes færdigheder på en række områder. Det at komme i gang med en uddannelse og skulle til at læse i den forbindelse har også i andre undersøgelser vist sig at have positiv effekt på voksnes læsefærdigheder (Arnbak og Borstrøm, 2004). Hos SOSUkursisterne ses signifikant fremgang på opgaver, der er relateret til uddannelsen - biologifagsteksten, sundhedsfagligt ordkendskab, sundhedsfaglige teksttyper - men der sås også en generel effekt på deres afkodning og læsning af voksne almentekster. I de hidtidige analyser er de 43 kursister behandlet som en gruppe, men de har jo modtaget forskellig undervisning i læsestrategier. LÆS SMART-gruppen er blevet undervist efter et træningsprogram, der er udviklet specielt til denne undersøgelse, hvor undervisningen i læsestrategier foregik som en integreret del af undervisningen i sundhedsfag, og kontrolgruppen har fået læsevejlederens kursus i læsestrategier, som ikke er en integreret del af undervisningen i fagene, samt et tilbud om frivillig ekstraundervisning. I de næste analyser ser vi nærmere på, om vi i undersøgelsen kan se en særlig effekt af LÆS SMART.

\subsection{Effekt af LÆS SMART}

For at vurdere, om der var effekt af LÆS SMART, lavede vi multivariate ANOVAer med repeated measures, hvor det blev undersøgt, om LÆS SMART-kursisterne gik mere frem end kontrolkursisterne på færdigheder før og efter træningsforløbet. Der var ikke større fremgang i LÆS SMARTgruppen end i kontrolgruppen på nogen mål. Der var dog en tendens til, at LÆS SMART-kursisterne på en lang række af før-testene havde et lidt 
dårligere udgangspunkt (forskellene var ikke signifikante). Derfor har vi også lavet univariate ANCOVA-er, hvor der i sammenligningerne tages højde for kursisternes prætestscore, men heller ikke disse analyser viste signifikant forskel mellem LÆS-SMART-kursisterne og kontrolkursisterne.

\subsection{Kursisternes evaluering af LÆS SMART}

De kursister, der deltog i LÆS SMART-forløbet, blev efter forløbets afslutning bedt om at svare på nogle spørgsmål om forløbet. Nedenstående er baseret på de kursister, der deltog i samtlige testgange.

Alle kursisterne har deltaget i alle eller de fleste af timerne (33\% i alle timer, $67 \%$ i de fleste timer), og eftersom der er mødepligt på uddannelsen, er det ikke så overraskende. $88 \%$ har altid lavet deres hjemmearbejde eller har lavet det meste af det, mens $13 \%$ svarer, at de næsten ikke eller slet ikke har lavet deres hjemmearbejde. $50 \%$ svarer, at de har været glade for at deltage i LÆS SMART, og 17 \% svarer, at de ikke har været glade for det. Den sidste del af kursisterne ved ikke, hvad de skal synes om det. Sværhedsgraden ser ud til at have passet fint til størsteparten af kursisterne. Således svarer kun 8 \%, at det har været for svært, mens $29 \%$ siger, at det har været for nemt. (50\% svarer uenig til for nemt, og $71 \%$ svarer uenig til for svært, hvilket måske er et udtryk for, at en stor del af kursisterne har haft svært ved at vurdere forløbets sværhedsgrad). $29 \%$ mener, at der ikke har været tid nok til forløbet. En del af kursisterne har tilsyneladende haft en oplevelse af, at forløbet er blevet for komprimeret, så der ikke har været tilstrækkelig tid til at fordøje, konsolidere og implementere de enkelte strategier.

Størsteparten af LÆS SMART-kursisterne (ca. $90 \%$ ), syntes, at LÆS SMART er et godt redskab, som kan bruges af dem selv og/eller af deres medkursister. $58 \%$ af kursisterne svarer, at de har brugt LÆS SMART i nogle af de andre fag i løbet af deres uddannelsesforløb. $33 \%$ svarer, at de også vil bruge arkene i fremtiden, selvom de ikke længere går på Social- og sundhedshjælperuddannelsen. Samlet tyder besvarelserne på, at LÆS SMART-forløbet har efterladt et så positivt indtryk hos kursisterne, at de 
allerede er i gang med at implementere redskabet som en del af deres faste „æsebagage“. Det er sandsynligt, at det i fremtiden vil gøre disse voksne til mere aktive læsere både i forbindelse med (videre-)uddannelse og erhverv.

Kursisterne blev også bedt om at vurdere, hvor brugbare de enkelte LÆS SMART-ark er. Her er det typiske svar, at arket kan bruges, men at kursisten ikke selv vil bruge det (ark 1-54 \%, ark 2-54 \%, ark 3-33\%, ark 4-67\%). Det eneste ark, som mange kursister (58 \%) vil bruge, er ark 3Styr på teksten, hvor man skulle stille spørgsmål til teksten. Næstflest (33 \%) svarer, at de vil bruge ark 1- Kom godt i gang, hvor kursisterne skulle gøre sig klar til teksten ved at kigge på særlige tekstelementer og overskrifter og aktivere deres forhåndsviden. Ark 4-Husk hvad du læser mente $21 \%$ af kursisterne, at de ville bruge i fremtiden. I ark 4 samler man op og forklarer, hvad man har lært af at læse den pågældende tekst. Ark 2-Lær nye ord ville færrest kursister (17\%) bruge fremover. Ark 2 var arket, hvor kursisterne skulle udfylde betydningsark for nye ord, og det er den aktivitet, der får flest kommentarer med på vejen. En skriver, at „ark 2 gjorde mig mere forvirret“. En anden skriver: „synes ikke noget skulle have været anderledes bortset fra Lær nye ord. Det giver slet ikke mening for mig forvirrer i stedet.“ En tredje anfører mere generelt, at „jeg har brugt unødigt ekstra tid på LÆS SMART. Jeg har ledt efter ord jeg „måske“ ikke kan forstå."

Flere kursister giver i øvrigt udtryk for, at tidspunktet for LÆS SMART burde ændres: „LÆS SMART burde ligge meget tidligere i SOSU“, dvs. i skoleperiode 1 frem for i skoleperiode 2, hvor det var placeret i vores træningsundersøgelse.

Afslutningsvis blev kursisterne bedt om at svare på, hvad de havde fået ud af LÆS SMART. Her svarede 58 \%, at de var blevet bedre til at forstå tekster, og hele $62 \%$ svarede, at de var blevet bedre til at huske det, de læste. $29 \%$ siger, at de er blevet hurtigere til at læse, og $46 \%$ svarer, at de er blevet bedre til at finde ud af, hvad svære ord betyder. En del af eleverne oplever således, at de har fået noget ud af forløbet, men det er svært at adskille, hvad de har lært af at være under uddannelse, og hvad de har lært, fordi de deltog i LÆS SMART-forløbet. Der er kun 25 \%, der svarer, at 
de er blevet bedre til at læse lektier efter deltagelse i LÆS SMART. Det er sandsynligt, at LÆS SMART-redskaberne ikke er blevet implementeret tilstrækkeligt i undervisningen til at blive en naturlig del af kursisternes lektielæsning.

Som det også fremgik af kursisternes resultater på læseforståelsesopgaverne, er der stor variation i gruppen af kursister, og denne variation har selvfølgelig stor betydning for, om man overhovedet synes, man kan bruge et sådant forløb til noget. Ved starten af uddannelsesforløbet havde $42 \%$ af kursisterne gode funktionelle læsefærdigheder (kategoriseret med udgangspunkt i vejledningen til Læsetekster for unge og voksne), og disse kursister vil ikke på samme måde føle, at de har brug for forløbet, fordi de ikke bliver udfordret af teksterne på SOSU-hjælperuddannelsen. Derfor kan deres ræsonnement være, at andre nok kan bruge LÆS SMART, men at de ikke selv har brug for det. Andre kursister har så store vanskeligheder med tilegnelsen af det faglige indhold på SOSU, at de har rigeligt at gøre med at prøve at hænge på, og derfor ikke har det store overskud til at bruge ekstra resurser på et sådant læsetræningsforløb. Det havde være dejligt, hvis vi havde mulighed for at se nærmere på særlige delgrupper blandt kursisterne eksempelvis LÆS SMART-kursister, der havde god læsefærdighed ved uddannelsens start, men desværre endte vores grupper med at blive meget små. Kun $30 \%$ af de oprindelige deltagere deltog $\mathrm{i}$ samtlige testgange, og derfor er det ikke muligt at se på undergrupper i den trænede gruppe.

Resultaterne af træningsundersøgelsen kan sammenfattes i følgende punkter:

- En stor del af de kursister, der begynder på Social- og sundhedshjælperuddannelsen, har svært ved at læse og forstå hverdagstekster og fagtekster. En stor del af denne variation kan forklares ud fra variation i kursisternes ordkendskab, afkodning og kendskab til teksttyper

- I løbet af uddannelsen udvikler SOSU-kursisterne sig på områder, der er knyttet til undervisningen. De bliver bedre til at læse og forstå faglige tekster (biologi), får et bedre sundhedsfagligt ordkendskab og 
kan bedre navigere i sundhedsfaglige teksttyper. Samtidig bliver SOSUkursisterne også bedre til at afkode og til at læse hverdagstekster. Det ser altså ud som om, at uddannelsesforløbet også har en positiv effekt på kursisternes generelle læsefærdighed

- Der var ikke nogen specifik effekt af at deltage i LÆS SMART-forløbet. Kursisterne, der havde deltaget i dette forløb, gik ikke mere frem på læsemålene end de øvrige kursister. Hovedparten af LÆS SMARTkursisterne udtrykker tilfredshed med forløbet, og mange af dem giver udtryk for, at de har lært nogle strategier, som de kan bruge senere hen. Det påfaldende er, at rigtig mange af kursisterne svarer, at det er godt og relevant, og de tror, at deres medkursister har brug for det men de har ikke selv brug for det

- Der en tendens til, at kursisterne vurderer deres læsefærdigheder (for) højt, når man ser på, hvor stor en del af kursisterne der har vanskeligheder med læseforståelsesopgaverne 



\section{Overvejelser og perspektivering}

Som det fremgår af rapporten havde programmet ikke den forventede effekt på kursisternes færdigheder. Det rejser naturligvis spørgsmålet, om det er de rigtige elementer, der er fokuseret på i træningsforløbet, men samtidig er det også en anledning til at reflektere over, hvilke forhindringer projektet er stødt på undervejs, og hvordan disse kan have haft en negativ effekt på resultaterne.

En faktor, der nok har spillet ind, er, at noget af forløbet blev afviklet som selvstudie, hvilket ikke var den oprindelige plan. Træningen var opdelt i 4x5 moduler, men i praksis blev de 20 moduler ikke afviklet på forskellige undervisningsdage. Undervisningen i Sundhedsfag var et ret komprimeret forløb placeret på få dage med mange timers undervisning. Det betød, at man afviklede flere LÆS SMART-moduler den samme dag, og at dele af forløbet blev afviklet som selvstudie. Indimellem var der (for) kort tid til at øve sig på de enkelte strategier, fordi man påbegyndte en ny strategi umiddelbart efter, og andre gange var der (for) langt mellem introduktion og opfølgning, så det næsten føltes som at starte forfra. Træningsforløbet stødte således på skematekniske forhindringer, der bevirkede, at modulerne ikke blev lagt, som man ville gøre i et ideelt træningsforløb. Ved en eventuel fremtidig træningsundersøgelse bør man sikre sig, at den faglige undervisning ikke bare har en vis tyngde i studieplanen, men også er fordelt på så mange undervisningsgange, at man skaber et kontinuerligt undervisningsforløb med fagintegreret læseundervisning som en gennemgående aktivitet. Man kunne fx fordele træningsforløbet på alle undervisningsdage og dermed også inddrage flere fag. Det ville give flere muligheder for at udnytte redskaberne og for at bruge strategierne på forskellige typer af tekster. 
Flere af kursisterne giver udtryk for, at de gerne ville have haft forløbet i skoleperiode 1, fordi de så kunne bruge det i skoleperiode 2 og 3 . I så fald kunne implementeringsfasen have været længere, og en del af implementeringsfasen kunne afvikles med kyndig vejledning fra undervisere i alle fag. Skal man evaluere det konkrete undervisningsforløb, så endte det med at blive for komprimeret, og det ville nok også have været en fordel at inddrage de øvrige fag mere aktivt, så LÆS SMART var blevet et redskab, man arbejdede med i alle fag og ikke bare i Sundhedsfag.

Vi kunne med fordel have haft faglærerne på et længere kursus inden træningsperioden, så de fik en grundig indføring i de generelle læsepædagogiske overvejelser bag sådan en træning. I stedet blev vores træning af underviserne et spørgsmål om at gøre underviserne parate til at gennemføre træningsperioden time for time. På en måde kan man sige, at de blev uddannet samtidig med deres elever, og at de derfor ville være langt bedre klædt på, hvis de skulle varetage den fagintegrerede læseundervisning på et kommende hold. Når man er ved at lære en metode, kan man ikke tænke det ind i de øvrige aktiviteter, og de øvrige lærere havde heller ikke mulighed for at tænke det ind i deres undervisning, eftersom de ikke havde kendskab til indholdet af forløbet.

Det diskuteres løbende, hvem der skal varetage undervisningen i faglig læsning. Skal det være læsefaglige personer eller fagfaglige personer? Det ideelle ville nok være, at en læsefaglig person stod for introduktion, modellering og afprøvning i fællesskab, mens faglæreren efter et samlet lærerkursus om faglig læsning og brug af strategiarkene skulle arbejde aktivt med implementeringsfasen ved at knytte strategiarkene til de enkelte fag.

Spørgsmålet er imidlertid, om den måde, undervisningen på SOSU er organiseret, muliggør et sådant forløb, eller om forløbet skulle tænkes ind i nogle andre rammer. Erhvervsuddannelserne indeholder så få undervisningstimer, at underviserne hurtigt vil føle, at de kommer til at bruge for meget af deres faglige undervisningstid på forløbet. Hvis man vil gennemføre et obligatorisk læsetræningsforløb på SOSU eller en anden erhvervsuddannelse i fremtiden, kan det anbefales, at man udvider timetallet svarende til træningsforløbets varighed, så der bliver plads til forløbet i det komprimerede uddannelsesforløb. Det ville betyde, at uddannelseslede- 
ren eller faglæreren ikke følte sig fagligt presset ved at skulle indtænke arbejdet med basisfærdigheder i (faglig) læsning, skrivning og stavning. Et obligatorisk forløb ville desuden betyde, at man fik fat i hele målgruppen og ikke skulle bruge den sparsomme tid på screeningsprocedurer, hvor kun en mindre del af kursisterne efterfølgende tager initiativ til at modtage frivillig undervisning.

Alternativt kunne grundskolens udskolingsklasser være en fin platform for et LÆS SMART-forløb, hvor dansklæreren/læsevejlederen var tovholder og koordinator, og hvor arbejdsmetoden blev integreret i fagene af de enkelte faglærere. I udskolingen skal eleverne i høj grad kunne tilegne sig viden fra fagtekster, og mange af dem bliver kraftigt udfordret på dette område i forbindelse med projektopgaver. Et LÆS SMART-forløb ville gøre eleverne mere parate til at opfylde de læsekrav, der stilles i ungdomsuddannelserne, og måske ville det også bevirke, at frafaldet på ungdomsuddannelserne blev mindre. Hvis LÆS SMART-programmet skal anvendes i udskolingen, vil det kræve en justering og udbygning af programmet.

En anden problemstilling er, om vi har fokuseret på de rigtige forståelsesstrategier i træningsforløbet i forhold til de konkrete fagtekster på SOSU. Alle de inddragne strategier har i tidligere træningsundersøgelser haft positiv effekt på elevernes læseforståelse, men den begrænsede træningsperiode har måske betydet, at der ikke var tid til at arbejde nok med de enkelte strategier. Derfor havde det måske givet større effekt at begrænse antallet af strategier, så der blev mere tid til arbejdet med den enkelte strategi.

Som udgangspunkt var dette projekt rettet mod elever, der kan læse og forstå en almindelig tekst, men som har svært ved at tilegne sig faglig viden på skrift. Dermed skulle projektet ikke rette sig mod ordblinde (elever med basale ordlæsevanskeligheder) eller fremmedsprogede elever (elever med store dansksproglige vanskeligheder). Begge elevtyper indgår imidlertid som en del af variationen på Social- og sundhedshjælperuddannelsen, og for disse elever kan et fagligt læsekursus måske være for krævende oveni den faglige undervisning. Omvendt er det bestemt ikke alle kursister, der føler sig udfordret af fagteksterne på SOSU, og for disse kursister kan det være svært at se relevansen af forløbet. Den store varia- 
tion i kursisternes læsefærdigheder betyder, at det er svært og muligvis umuligt at ramme plet med ét samlet tilbud.

Kun en lille del af kursisterne deltog i samtlige testgange. Det betød, at vores endelige datamateriale ikke var så omfattende, at vi havde mulighed for at se på undergrupper i træningsgruppen. Det kan eksempelvis tænkes, at netop kursister med god basal læsefærdighed men med funktionelle læsevanskeligheder har haft udbytte af forløbet. De svageste kursister kan have manglet de nødvendige forudsætninger for at udnytte de indlærte strategier, og kursister med gode læsefærdigheder har måske allerede anvendt nogle af strategierne ubevidst og har derfor ikke haft gavn af forløbet.

Der gøres et stort arbejde på erhvervs- og ungdomsuddannelser for at udpege de svage læsere og for at problematisere brugen af for svære tekster i undervisningen. Men det nytter ikke at udpege de svage læsere, hvis de ikke får den nødvendige læsehjælp. Det nytter heller ikke at problematisere brugen af de eksisterende tekster, hvis der ikke sættes noget i stedet. Vores undersøgelse peger på, at der stadig mangler det nødvendige fokus på, hvordan et uddannelsesforløb tilrettelægges, så kursisterne ikke bare tilegner sig det faglige indhold, men også lærer selv at tilegne sig det faglige indhold. I et samfund, der bygger på livslang læring, er det en kritisk forudsætning, at man kan tilegne sig viden på egen hånd. Vores analyser understreger, at fagtekster til SOSU har en vis sværhedsgrad på tekstog ordniveau som følge af deres særlige faglige karakter, uanset hvor let tilgængelige de måtte være på sætningsniveau. Det svarer til, hvad man har set i fagtekster til andre tilsvarende uddannelser. Det er således ikke en løsning, at vi gør teksterne lettere at læse, hvis vi ikke samtidig skaber det nødvendige fokus på også at gøre teksterne lette at lære. Så længe der mangler undervisningsvejledninger til de fleste fagbøger over grundskoleniveau, er det usandsynligt, at undervisere uden særlig læsefaglig indsigt og kursister med begrænset skolebaggrund har et tiltrækkeligt fokus på, hvad der egentlig kræves for at læse fagtekster med tilstrækkeligt udbytte. 


\section{Litteratur}

Arnbak, E. Gandil, T. \& Hauerberg Olsen, M. (2009). Udredning af de faktiske læsekrav på pædagoguddannelsen på et udvalgt seminarium. Projekt 1: Studieteksternes sproglige og indholdsmæssige tilgængelighed - analyser. Kan rekvireres fra Statens Styrelse for Uddannelsesstøtte.

Arnbak E. \& Gandil, T. (2010). Pilotafprøvning af metode til udredning af de faktiske læse- og skrivekrav på et pædagogseminarium. Styrelsen for Statens Uddannelsesstøtte.

Arnbak, E. \& Borstrøm, I. (2004). FVU-deltageres bevidsthed om og udbytte af læse-, stave- ogskriveundervisning - en afprøvning af to undervisningsmaterialer. København: Undervisningsministeriet.

Arnbak, E. (2003). Faglig læsning - fra læseproces til læreproces. København: Gyldendal.

Arnbak, E. (2001). Læsetekster for unge og voksne, vejledning. København, Dansk Psykologisk forlag.

Arnbak, E. (2001). Læsetekster for unge og voksne, prøvehæfte. København, Dansk Psykologisk forlag.

Arnbak, E. (1999). Faglig læsning I AMU - en undersøgelse af sammenhængen mellem AMU deltageres funktionelle læsefærdighed og deres faglige læsning. København: Arbejdsmarkedsstyrelsen

Arnbak, E. \& Elbro, C. (1999). Læsning, læsekurser og uddannelse. København, Undervisningsministeriets Forlag.

Baker, S., Gersten, R. \& Grossen, B. (2002). Interventions for Students With Reading

Comprehension Problems. In Shinn, M. R., Walker, H.M. \& Stoner, G. (Eds.). Interventions for academic and behavior problems II: Preventive and remedial approaches (s. 731-754). Wasington, DC, US: National Assosiation of School Psychologists.

Barton, P. E. (2000). What jobs require: Literacy, Education, and Training 1940-2206. Policy

Information Report. Educational testing Service, Princeton NY.

Baumann, J. F. (2009). Vocabulary and reading comprehension. In Israel, S. E. \& Duffy, G.G. (Eds.). Handbook of research on reading comprehension. Routledge: NY. Baumann, J. F., Edwards, E. C., Boland, E. M., Olejnik, S. \& Kame'enui, E. (2003). Vocabulary tricks: Effects of instruction in morphology and context on fifth-grade 
students' ability to derive and infer word meanings. American Educational Research Journal, 40 (2), 447-494.

Berthelsen, H. E. (1994). Ny biologi 1. København, Gyldendal undervisning.

Björnsson, C. H. (1971, opr. 1968). Læsbarhed. København. Gad.

Borstrøm, I., Petersen, D. K. \& Elbro, C. (1999) Hvordan kommer børn bedst i gang med at læse? København: Center for læseforskning, Københavns Universitet.

Bos, C. S. \& Anders, P. L. (1990). Effects of interactive vocabulary instruction on the vocabulary learning and reading comprehension of junior-high learning disables students. Learning disability Quarterly, 13 (1), 31-42.

Brinckmann, H. \& Poulsen, J.A. (1997). Maden, magten og danskerne.

København, Gyldendal Undervisning.

Carstensen, L., Møller, K. \& Svankier, I. (2010). Social- og sundhedshjælper - bind 1. København: Munksgaard.

Carstensen, L., Møller, K. \& Svankier, I. (2010). Social- og sundhedshjælper - bind 2. København: Munksgaard.

Carstensen, L., Møller, K. \& Svankier, I. (2009). Social- og sundhedshjælper - bind 3. København: Munksgaard.

Christensen, B, Duncker, D, Larsen, B. \& Lyngvig, R.(1989). Sprogmagisteren. Forlaget Sporskiftet - Konsulentfirmaet Bøje Larsen, www.kbl.dk

Christensen, L. W. (1999). Læsefærdigheder. Læsning = afkodning * forståelse * genrekendskab* Strategier. København: Københavns Universitet (speciale).

Elbro, C. (2006). Læsning og læseundervisning. København. Gyldendal.

Elbro, C., Møller, S., \& Nielsen, E. M. (1991). Danskernes læsefærdigheder.

En undersøgelse af 18-67-åriges læsning af dagligdags tekster. Projekt Læsning og Undervisningsministeriet.

Gabrielsen, E., Haslund J. \& Lagerstrøm, B.O. (2005). Lese- og mestringskompetanse i den norske voksenbefolkningen. Resultater fra „Adult Literacy and Life Skills“ (ALL). Stavanger: Universitetet i Stavanger. Lesecenteret.

Gabrielsen, E. (2000). Slik leser voksne i Norge. En kartleggning av leseferdigheden I aldersgruppen 16-65 år. Stavanger. Senter for leseforskning.

Gellert, A. S., Elbro, C., Gabrielsen, E., Lavås, I., Lund, R. \& Ojanen, E. (2007). Forbedring af læse-, skrive- og it-færdigheder for kortuddannede voksne - en nordisk forundersøgelse. (TemaNord 2007:549). København: Nordisk Ministerråd.

Gellert, A. (1999). „Hvordan kan man forudsige forskelle i elevers læseforståelse af faglige uddannelsestekster?“ Psykologisk Pædagogisk Rådgivning 5-6: 395-418.

Gellert, A. (upubliceret manuskript).,,Reading Comprehension, vocabulary knowledge and decoding skills in commercial school students." Center for Læseforskning, Københavns Universitet.

Gissel, S. T. (2009). Analyse og vurdering af Social- og sundhedshjælper. Videnscenter for læremidler. 
Gustavsson, A-L.E. (1997). Att läse - ett behov, ett krav, en nödvändighet. En analys av den förste internationellt jämförende studien av vuxnes förmåga att förstå och använda skriftlig information. International Adult Literacy Survey. Linköpings Universitet: Institutionen för pedagogik och psykologi.

Henrichsen, P. J. (2009). Kvalitativ bestemmelse af informationstætheden i 15 danske studietekster. Bilag 3 i Arnbak, E. Gandil, T., og M. Hauerberg Olsen (2009) Udredning af de faktiske læsekrav på pædagoguddannelsen på et udvalgt seminarium. Projekt 1: Studieteksternes sproglige og indholdsmæssige tilgængelighed. del 1, analyseapparat. August 2009. Kan rekvireres af Statens Styrelse for Uddannelsesstøtte.

Holders, B., Petersen, D.K., Borstrøm, I. \& Elbro, C. (1996). Undervisning af voksne ordblinde. En undersøgelse af undervisningseffekt og lærerkvalifikationer i ordblindeundervisningen i AOF. København: Forlaget Skolepsykologi.

Hoover, W. \& Gough, P. (1990). The simple view of reading. Reading and Writing: An interdisciplinary Journal, årgang 2, s. 127-160.

Hull, G. Jury, M. Ziv, O. \& Katz, M. (1996). Changing work, changing literacy: a study of skill requirements and development in a traditional and restructured workplace. Final report. Berkely, CA: National Center for Research in Vocational Education, Center for the Study of Writing and Literacy.

Institute of Education Sciences. (2008). Improving Adolescent Literacy: Effective Classroom and Intervention Practices. National center for education evaluation and regional assistance. Institute of Education Science. US Department of Education. (http://ies.ed.gov/ncee/wwc/practiceguide.aspx?sid=8)

Jensen, T.P., Andersen, A. \& Halgreen, T. (2001) Læsefærdigheder og deltagelse i samfundslivet. København: Amternes og Kommunernes Forskningsinstitut og Specialarbejderforbundet i Danmark.

Jensen, T. P. \& Holm, A. (2000) Danskernes læse-regne-færdigheder - i et internationalt lys, AKF Forlaget, 2000.

Jensen, T. P. \& Holm, A. (2000b). Læsekurser for voksne, udbytte og tilrettelæggelse. København: AKF RAPPORT.

Kamil, M. (2004). Vocabulary and Comprehension instruction. In P. McCardle and Vinita Chhabra (Eds). The Voice of Evidence in Reading Research. Maryland.

Karlsson, A. (2006). Reading to be independent, writing to be controlled? Roles and literacies offered to workers in modern organisations. Stockholm: Stockholms Universitet, Institutionen for nordiska språk.

Kabel, K., Gissel S. T. \& Carlsen, D. (2009). Læsbare læremidler EUD. EMU Rapport.

Katims, D. S \& Harris, S. (1997). Improving reading comprehension of middle school students in inclusive classrooms. Journal of Aodlescent and Adult Literacy, 41 (2), 116-123.

Knudsen, L. (2003). Læseforståelse og tekstgenrer. København: Landsforeningen af Læsepædagoger. Læserapport 37. 
Knudsen, L. (2003b). En effektundersøgelse af direkte undervisning i genrekendskab. I Den Gule Serie. Læsepædagogen.

Lau, J., Holst, C.; Brøcker, A. \& Klausen, A.B. (1995). Nytter det noget? - om den kompenserende specialundervisning for læse- og stavehandicappede i Århus Amt. København: Danmarks Pædagogiske Institut.

Lund, K., Bertelsen, E. \& Sørensen, M.S. (2006). Muligheder og barrierer - en undersøgelse af overgangen mellem sprogcentre og erhvervsrettede uddannelser. København: Ministeriet for Flygtninge, Indvandrere og Integration.

McNamara. D. S, de Vega, M., \& O'Reilly, T. (2007). Comprehension skill, inference making, and the role of knowledge. In F. Schmalhofer \& C. A. Perfetti (Eds.) Higher level language processes in the brain: Inference and comprehension processes (pp. 233-253). Mahwah, NJ: Lawrence Erlbaum Assiociates.

McNamara, D. S. Kintsch, E., Songer, N.B. \& Kintsch, W. (1996). Are Good Texts Always better? Interactions of textcoherence, background Knowledge, and levels of understanding in learning from text. In Cognition and Instruction, 14,1.

Mickulecky, L. (2000). Developing and Teaching in Workplace Literacy Programs. Paper presented at the Annual Meeting of the International Reading Association. Indianapolis.

Mickulecky, L. (1998). Transfer beyond workplace literacy classes: twelve case studies and a model. Reading-Psychology, 19, 51-138.

Møller, S. (2010). Samspil mellem AMU og FVU - 12 gode eksempler. Undervisningsministeriets temahæfteserie nr. 3.

Møller, S. \& Nielsen, R. (1986). Svage læsere eller dårlige tekster? En undersøgelse af tekster og læsere på kurser for specialarbejdere. Pædagogiske forskningsrapporter nr. 35, København: Læsepædagogen.

National Reading Panel. (2000). Teaching children to read: AN evidence-based assessment of the scientific research literature on reading and its implications for reading instruction. Washington DC. The National Institute of Child Health and Human Development (wwwe.nifhd.nih.gov/publications/nrp)

Nielsen, I. \& Petersen, D. K. (1992). Diavok, et materiale, der afdækker eventuelle læse- og stavevanskeligheder. København: AOFs forlag.

OECD/PISA (1998). Framework for Assessing Reading Reading.

Pedersen, L.B.T. \& Løvengreen, K. (2006). Brancherettet FVU - et idékatalog om information og tilrettelæggelse af FVU på virksomheder. København: FVU-team Storkøbenhavn.

Petersen, D.K. (2008). Hvad har betydning for elevers læseforståelse? København: Landsforeningen af Læsepædagoger. Læserapport 44.

Perfetti, C.A., Landi, N. \& Oakhill, J. (2005). The Acquisition of Reading Comprehension Skill. I: The Science of Reading: A Handbook, s. 227-247. UK: Blackwell Publishing.

Rosenshine, B. \& Meister, C. (1994). Reciprocal Teaching: A Review of the Research. I Review of educational research, 64 (e). 
Rønberg, L. \& Petersen, D.K. (2011). Hvilke færdigheder har betydning for læseforståelse på mellemtrinnet? Læsepædagogen, årgang 59, nr. 2, s. 4-10.

Samuelstuen, M. S. \& Bråten, I. (2005). Decoding, knowledge, and strategies in comprehension of expository text. Scandinavian Journal of Psychology, 46, s. 107-117.

Schmidt, M. C. (1990). A questionaire to measure children's awareness of strategic reading processes. The reading teacher. 454-461.

Trepartsudvalget (2006) Livslang opkvalificering og uddannelse for alle på arbejdsmarkedet rapport fra Trepartsudvalget - Bind 1: Den fremtidige voksen- og efteruddannelsesindsats. København: Finansministeriet.

Undervisningsministeriet (2005). Det nationale kompetenceregnskab - Hovedrapport. København: Undervisningsministeriet. 



\section{English summary}

In autumn 2009 Nordic Council of Ministers decided to support an intervention study with reading comprehension instruction integrated in the disciplines in adult education. The purpose of the study was to develop and test a reading comprehension intervention, which was based on the reading material in a specific education. Another purpose was to evaluate the effect of the comprehension instruction in an intervention study.

The study was made on a Basic Health Care College in Greve, which is a municipality $25 \mathrm{~km}$ from Copenhagen. The Basic Social and Health Education was chosen for several reasons. This education is known to have great share of poor readers. It is necessary to read and write during the education and later on in their daily work. During the Basic Social and Health Education the students have periods in school and periods with practical work at a workplace, and reading and writing is a part of the primary job functions. Previously the Basic Social and Health Education was a 9 week course, and now it is an education which is completed after one year and seven months. The current study also included analysis of the reading material from the chosen education, and it was a great advantage that the majority of the Basic Health Care Colleges in Denmark used the same textbooks. This would make the textbook analysis relevant to others than the Basic Health Care College in Greve.

The next step in the study was to choose the discipline, where the reading comprehension instruction should be integrated. In order to make the right choice we made different investigations. In December 2009 and January 2010 a questionnaire was sent to the teachers and the students at the Basic Health Care College in Greve. In their answers the teachers described the students' reading and writing skills as a barrier in their daily teaching. The students answered that the textbooks in specific disciplines were very difficult. Based on the questionnaires we chose two disciplines 
and a project-course, which we observed at the college. It was a domain discipline (Health) and a basic discipline (Science) and a course where the students should make a report about a client (called a Problem-BasedLearning course). During spring 2010 we observed the teaching of these 3 disciplines at the Basic Health Care College in Greve in order to find the right discipline for the reading comprehension instruction. Finally Health was chosen, because it was a core discipline in the Basic Social and Health Education, and the textbook was used actively in the teaching of the discipline. The students also seemed very dedicated to this discipline, and we thought that this enthusiasm might be a good fundament for the reading comprehension instruction.

Linguistic analyses were made with the textbook from Health. These analyses revealed that the textbook had a lot of passive sentences and a high information density. But the linguistic complexity of the textbook was not greater than other discipline-specific texts. The health textbook consisted of different kinds of texts (instructions, diagrams, tables, lists) and this might make the textbook more complex, because the reader needs to know when to use different reading strategies depending on the text structure. The discipline-specific vocabulary and language in the textbook also makes it necessary to master specific reading and study strategies.

It is not possible to make a thorough analysis of all the textbooks at a specific education in order to make a linguistic rewriting of these. Therefore it is important to focus on the actual literacy skills needed for the domain-specific texts in the specific education and teach the students the necessary reading comprehension strategies.

An intervention program was developed for the study. The intervention program was called READ SMART, and the focus of the intervention was reading comprehension strategies. READ SMART was designed especially for the Health lessons at the Basic Social and Health Education. The intervention program consisted of four main elements, and these elements were trained in 20 modules followed by a phase of implementation, where the students used the strategic tools from the intervention, when they were doing their homework. The elements in the intervention were a "before reading strategy", a "while you are reading strategy" and two "af- 
ter you have read strategies". The program was developed based on results from meta-analyses of methods in reading comprehension instruction. The themes of the intervention were knowledge about text structure, activating relevant knowledge, vocabulary, asking questions, making summaries and inference making.

The students worked with the strategies in phases. In the first phase the strategy was introduced by the teacher, and in the second phase the strategy was modeled by the teacher. The next phase for the students was to use the strategy with a partner, and afterwards the student had to use the strategy alone at home. In the final phase the strategy was repeated in the classroom, and afterwards the students were asked to use the strategy when they were doing their homework to make sure, that the students implemented the strategy as a part of their strategic tools.

The students reading comprehension, vocabulary, decoding, knowledge of text structure and metacognitive strategies were assessed before and after the READ SMART intervention. The students also answered a questionnaire about their reading habits. The students were divided in a control group and an experimental group, who received the READ SMART training. The students in the READ SMART group also answered a questionnaire, where they were asked to evaluate the READ SMART intervention.

The assessments of the students' skills made it possible to characterize and compare the groups and to evaluate specific and general effects of the READ SMART intervention. Half of the students on the Basic Health Care College in Greve had poor functional reading skills (newspaper articles, recipes etc.) and difficulties with discipline-specific texts (Biology and History). The major part of the variation in the students' reading comprehension is explained by their vocabulary, decoding and knowledge about text structure.

The students in this project improved their skills in some but not all areas. During their education the students' comprehension of domain-specific text (Biology), their domain-specific vocabulary (Health) and their knowledge of domain-specific text structure (Health) improved. The stu- 
dents' decoding skills and functional reading skills also improved probably because they got a lot of experience with reading during their education.

There was no specific effect of the READ SMART intervention in the current study. There was no significant difference between the progress in the READ SMART group and the control group. But when answering the questionnaire the students in the READ SMART group expressed satisfaction with the intervention. The majority of the students in the READ SMART group said, that they have learned some strategies they would use in the future. This result replicates other studies with adults who also found lack of measureable effects of a short intervention, but where the participants thought they have learned something they could use later on (see for example Arnbak \& Borstrøm, 2004). This intervention might be the necessary kick-start which later on will lead to positive effect on the students' reading comprehension. 


\section{Nordisk Ministerråd}

Ved Stranden 18

DK-1061 København K

www.norden.org

\section{Fagintegreret læseundervisning for kortuddannede voksne}

Er det muligt at øge voksnes faglige læseforståelse gennem den almindelige faglige uddannelse, og hvordan tilrettelægger man en veldokumenteret fagintegreret læseundervisning for voksne?

Det belyser denne undersøgelse, som blev afviklet på Social- og sundhedshjælperuddannelsen i Greve. Undersøgelsen beskriver, hvilke særlige læsekrav en fagbog stiller til sin læser, og giver et overblik over metoder i arbejdet med læseforståelsesstrategier. Endelig præsenteres et særligt LÆS SMART-forløb, der afprøves i faget Sundhedsfag på Social- og sundhedshjælperuddannelsen, og resultaterne af effektundersøgelsen og de videre perspektiver diskuteres. 